\title{
PENGEMBA NGAN METODE PENETAPAN KADAR CAMPURAN PEMANIS, PENGAWET DAN PEWARNA SECARA SIMULTAN \\ DALAM SIRUP ESENS DENGAN MENGGUNAKAN KROMATOGRAFI CAIR KINERJA TINGGI
}

\section{TESIS}

\author{
Diajukan sebagai salah satu syarat untuk memperoleh \\ gelar Magister Farmasi pada Fakultas Farmasi \\ Universitas Sumatera Utara
}

Oleh:

SUPRIANTO

NIM 097014008

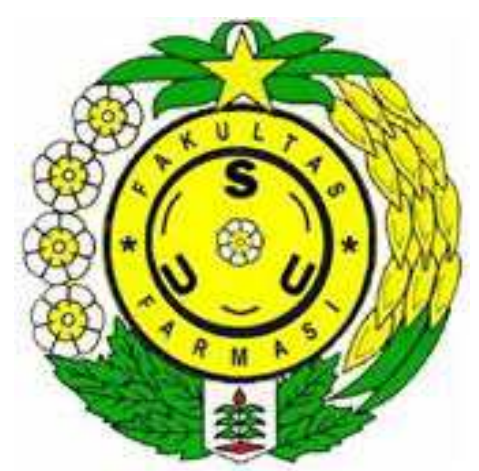

\section{PROGRAM STUDI MAGISTER FARMASI \\ FAKULTAS FARMASI \\ UNIVERSITAS SUMATERA UTARA \\ MEDAN}

2014 


\section{LEMBAR PERSETUJUAN TESIS}

$\begin{array}{ll}\text { Nama } & \text { : Suprianto } \\ \text { NIM } & : 097014008 \\ \text { Program Studi } & : \text { Magister Farmasi } \\ \text { Judul Tesis } & \text { : Pengembangan Metode Penetapan Kadar } \\ & \begin{array}{l}\text { Campuran Pemanis, Pengawet dan Pewarna } \\ \text { Secara Simultan dalam Sirup Esens dengan } \\ \end{array} \\ & \text { Menggunakan Kromatografi Cair Kinerja Tinggi }\end{array}$

Tempat dan Tanggal Ujian Lisan Tesis: Medan, 9 Januari 2014

Medan, Maret 2014

Menyetujui:

Komisi Pembimbing,

Ketua,

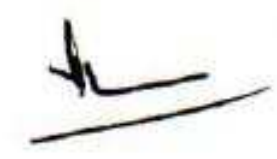

Prof. Dr. rer. nat. Effendy De Lux Putra, S.U., Apt.

NIP 195306191983031001

Anggota,

Prof. Dr. Sir Mo in sinaga, M.Sc., Apt.

NIP 195008281976032002

Mengetahui:

Ketua Program Studi,

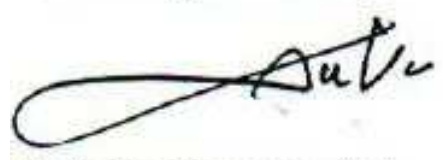

Prof. Dr. Karsono, Apt. NIP 195409091982011001

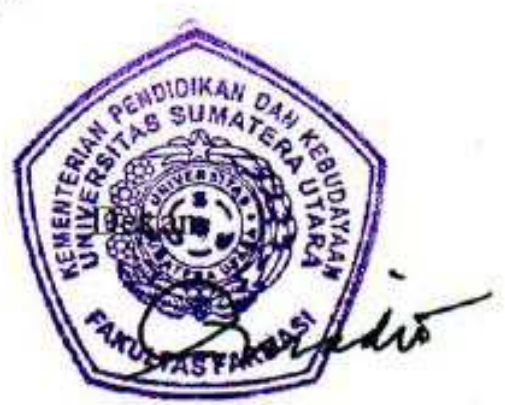

Prof. Dr. Sumadio Hadisahputra, Apt. NIP 195311281983031002 


\title{
LEMBAR PENGESAHAN TESIS
}

\author{
Nama Mahasiswa : Suprianto \\ No.Induk Mahasiswa : 097014008 \\ Program Studi $\quad$ : Magister Farmasi \\ Judul Tesis : Pengembangan Metode Penetapan Kadar \\ Campuran Pemanis, Pengawet dan Pewarna \\ Secara Simultan dalam Sirup Esens dengan \\ Menggunakan Kromatografi Cair Kinerja Tinggi
}

Telah diuji dan diny atakan LULUS di depan Tim Penguji pada Hari Kamis Tanggal Sembilan Bulan Januari Tahun Dua Ribu Empat Belas

Mengesahkan:

Tim Penguji,

Ketua Tim Penguji $\quad$ : Prof. Dr. rer. nat. Effendy De Lux Putra, S.U., Apt.

Anggota Tim Penguji : $\quad$ Prof. Dr. Siti Morin Sinaga, M.Sc., Apt.

Prof. Dr. Jansen Silalahi, M.App.Sc., Apt.

Dr. Ginda Haro, M.Sc., Apt. 


\title{
SURAT PERNYATAAN
}

\author{
Nama Mahasiswa $\quad:$ Suprianto \\ Nomor Induk Mahasiswa ： 097014008 \\ Program Studi $\quad$ : Magister Farmasi \\ Judul Tesis $\quad$ : Pengembangan Metode Penetapan Kadar Campuran \\ Pemanis, Pengawet dan Pewarna Secara Simultan \\ dalam Sirup Esens dengan Menggunakan Kromatografi \\ Cair Kinerja Tinggi
}

Dengan ini menyatakan bahwa tesis yang saya buat adalah hasil karya saya sendiri, bukan plagiat, dan apabila dikemudian hari diketahui tesis saya tersebut plagiat karena kesalahan saya sendiri, maka saya bersedia diberi sanksi apapun oleh Program Studi Magister Farmasi Fakultas Farmasi USU. Saya tidak akan menuntut pihak manapun atas perbuatan say a tersebut.

Demikian surat pernyataan ini saya perbuat dengan sebenarnya dalam keadaan sehat.

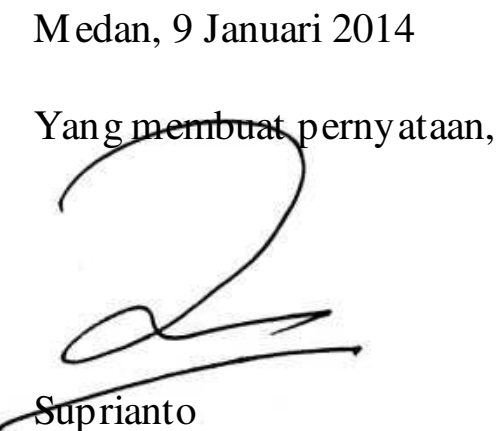

NIM 097014008 


\section{KATA PENGANTAR}

Puji dan syukur ke hadirat Allah SWT atas segala nikmat-Nya sehingga penulis dapat menyelesaikan penulisan tesis dengan judul Pengembangan Metode Penetapan Kadar Campuran Pemanis, Pengawet dan Pewarna Secara Simultan dalam Sirup Esens dengan Menggunakan Kromatografi Cair Kinerja Tinggi sebagai salah satu syarat untuk memperoleh gelar Magister Farmasi pada Fakultas Farmasi Universitas Sumatera Utara. Shalawat dan beriring salam saya haturkan untuk junjungan Rasulullah Muhammad SAW.

Penulis telah banyak mendapat bantuan dan motivasi dari berbagai pihak selama penulisan tesis ini sehingga penulis ingin menghaturkan penghargaan dan terima kasih kepada:

1. Rektor Universitas Sumatera Utara, Bapak Prof. Dr. dr. Syahril Pasaribu, DTM\&H., M.Sc., (CTM)., Sp.A.(K)., atas fasilitas yang diberikan kepada penulis selama men gikuti dan meny elesaikan Program Magister Farmasi.

2. Dekan Fakultas Farmasi Universitas Sumatera Utara, B apak Prof. Dr. Sumadio Hadisahputra, Apt., atas kesempatan dan fasilitas yang diberikan kepada penulis selama menjadi mah asiswa Program Studi Magister Farmasi.

3. Ketua Program Studi Magister Farmasi Fakultas Farmasi Universitas Sumatera Utara, Bapak Prof. Dr. Karsono, Apt., yang telah memberi motivasi kepada penulis dalam penyelesaian pendidikan Program Magister Farmasi.

4. Bapak Prof. Dr. rer. nat. Effendy De Lux Putra, S.U., Apt., selaku Pembimbing I dan Kepala Laboratorium Penelitian yang telah memberi saran, bimbingan, motivasi dan bantuan fasilitas laboratorium kepada penulis selama menjalani penelitian dan penulisan tesis ini. 
5. Ibu Prof. Dr. Siti Morin Sinaga, M.Sc., Apt., selaku Pembimbing II y ang telah memberi saran, bimbingan dan motivasi kepada penulis selama menjalani penelitian dan penulisan tesis ini.

6. Bapak Prof. Dr. Jansen Silalahi, M.App.Sc., Apt., dan Dr. Ginda Haro, M.Sc., Apt., selaku dosen penguji yang telah memberi arahan perbaikan penulisan tesis ini.

7. Bapak Sumardi, M.Sc., S.Si., Apt., selaku Supervisor yang telah memberi saran dan motivasi kepada penulis selama penelitian dan penulisan tesis ini.

8. Almarhummah Ibunda Martinah dan Ayahanda H. Sarijan y ang dengan sabar mendidik, membimbing, memotivasi dan mendo'akan dengan tulus selama penulis menjalani pendidikan.

9. Istri tercinta Latipa Komalasari, S.S., dan Ananda tersayang Fathia Rahma Dewi, Yusrizha Maharani, Eka Hasbi Habibi dan Assyfa Zahra Salsabila yang telah memberi motivasi selama penulisan tesis ini.

10. Seluruh staf laboratorium penelitian Fakultas Farmasi yang telah membantu dalam penelitian.

Serta seluruh pihak yang tidak dituliskan yang telah membantu dalam penyelesaian tesis ini. Semoga Allah SWT menjadikan sebagai amal ibadah yang tak ternilai hargany a dan memberikan balasan atas kebaikan tersebut.

Penulis menyadari bahwa tesis ini masih jauh dari kesempurnaan, sehingga penulis mengharapkan kritik dan saran yang bersifat membangun. Penulis juga berharap semoga tesis ini dapat menjadi sumbangan yang berarti bagi pengembangan ilmu pengetahuan.

Medan, 9 Januari 2014

Penulis, 


\title{
PENGEMBA NGAN METODE PENETAPAN KADAR CAMPURAN PEMANIS, PENGAWET DAN PEWARNA SECARA SIMULTAN DALAM SIRUP ESENS DENGAN MENGGUNA KAN KROMATOGRAFI CAIR KINERJA TINGGI
}

\begin{abstract}
Abstrak
Sirup merupakan larutan gula pekat dengan atau tanpa penambahan bahan tambahan pangan. Bahan pemanis, pengawet dan pewarna dapat mengganggu kesehatan bila dikonsumsi berlebihan. Tujuan penelitian adalah untuk mengembangkan metode penetapan kadar campuran natrium sakarin, natrium siklamat, natrium benzoat, kalium sorbat, tartrazin dan sunset yellow dalam sirup esens. Penelitian menggunakan kromatografi cair kinerja tinggi fase terbalik, tiga panjang gelombang dengan instrumen UFLC 1290 DAD (Agilent), kolom C18 $100 \mathrm{~mm} \times 4,6 \mathrm{~mm} \times 3,5 \mu \mathrm{m}$ (Agilent), spektrofotometer UV Probe 1800 (Shimadzu), bahan baku natrium sakarin, natrium siklamat, natrium benzoat, kalium sorbat, tartrazin dan sunset yellow. Parameter optimasi meliputi volume void, panjang gelombang, pH fase gerak, komposisi fase gerak, laju alir dan suhu kolom. Parameter validasi meliputi linearitas, batas deteksi, batas kuantitasi, akurasi, presisi dan selektivitas. Metode yang diperoleh digunakan untuk penetapan kadar campuran natrium sakarin, natrium siklamat, natrium benzoat, kalium sorbat, tartrazin dan sunset yellow secara simultan dalam sampel sirup esens. Sebanyak enam sampel sirup esens diperoleh dari grosir dan supermarket di Kota Medan dan diberi kode $\mathrm{H}, \mathrm{I}, \mathrm{J}, \mathrm{K}, \mathrm{L}$ dan $\mathrm{M}$.

Hasil penelitian menunjukkan bahwa kondisi optimum pengujian adalah volume void $30 \%$ dengan tiga panjang gelombang analisis, yaitu: $200 \mathrm{~nm}$ untuk natrium siklamat; $220 \mathrm{~nm}$ untuk natrium sakarin, natrium benzoat dan kalium sorbat; $450 \mathrm{~nm}$ untuk tartrazin dan sunset yellow. Fase gerak buffer fosfat $\mathrm{pH} \mathrm{4,5}$ dan metanol $75: 25$ (v/v), laju alir $1,0 \mathrm{ml} / \mathrm{men}$ it, suhu kolom $30^{\circ} \mathrm{C}$. Rentang waktu retensi adalah 0,941 menit - 8,583 menit. Hasil validasi metode menunjukkan bahwa rentang linearitas, batas deteksi, batas kuantitasi, akurasi, persen RSD keterulangan dan ketertiruan metode masing-masing 0,99945 - 0,99999; 0,03634 ppm - 2,66306 ppm; 0,12113 ppm - 8,87687 ppm; 92,92\% - 105,72\%; 0,11\% $1,53 \%$ dan $0,04 \%-1,94 \%$. Uji selektivitas metode menunjukkan hasil yang baik. Hasil penelitian menunjukkan bahwa kalium sorbat tidak terkandung dalam sampel sirup esens. Rentang kadar natrium sakarin, natrium siklamat, natrium benzoat, tartrazin dan sunset yellow dalam sampel sirup esens masing-masing 37,952 mg/kg - 533,990 mg/kg; 2753,140 mg/kg - 5329,890 mg/kg; 464,456 mg/kg - 1615,360 $\mathrm{mg} / \mathrm{kg} ; 41,957 \mathrm{mg} / \mathrm{kg}-108,048 \mathrm{mg} / \mathrm{kg}$ dan $31,084 \mathrm{mg} / \mathrm{kg}-145,399 \mathrm{mg} / \mathrm{kg}$. Sampel sirup esens men gandung kad ar natrium sakarin untuk kode I dan natrium benzoat untuk kode $\mathrm{H}$, J dan K melebihi batas penggunaan maksimum. Semua sampel sirup esens mengandung natrium siklamat melebihi batas penggunaan maksimum.
\end{abstract}

Kata kunci : Pemanis, Pengawet, Pewarna, Kromatografi Cair Kinerja Tinggi, Optimasi, Validasi, Sirup Esens. 


\title{
METHOD DEVELOPMENT OF SIMULTANEOUS DETERMINATION OF SWEETENERS, PRESERVATIVES AND DYES IN ESSENCES SYRUP USING HIGH PERFORMANCE LIQUID CHROMATOGRAPHY
}

\begin{abstract}
Abt ract
Syrup is concentrated sugar solution with or without the addition of food additives. Sweeteners, preservatives and dyes can be hazardous to health if they are over consumed. The purpose of this research was to develop a method for the simultaneous determination of sodium saccharin, sodium cyclamate, sodium benzoate, potassium sorbate, tartrazine and sunset yellow in essence syrup. This research used high performance liquid chromatography reverse phase, three wavelengths with UFLC 1290 DAD (Agilent), column C18 $100 \mathrm{~mm}$ x $4.6 \mathrm{~mm} \mathrm{x}$ $3.5 \mu \mathrm{m}$ (Agilent), spectrophotometer UV Probe 1800 (Shimadzu), standard material sodium saccharin, sodium cyclamate, sodium benzoate, potassium sorbate, tartrazine and sunset yellow. Optimization parameters were include void volume, wavelengths, $\mathrm{pH}$ of mobile phase, composition of mobile phase, flow rate and column temperature. Validation parameters were include linearity, limit of detection, limit of quantitation, accuracy, precision and selectivity. The method obtained was used for the simultaneous determination of sodium saccharin, sodium cyclamate, sodium benzoate, potassium sorbate, tartrazine and sunset yellow in essence syrup samples. A total of six essence syrup samples were obtained from wholesale and supermarket in Medan City and given code H, I, J, K, L and M.

The results of reseach showed that the optimum conditions were void volume $30 \%$ with three-wavelen gth analy sis, i.e: $200 \mathrm{~nm}$ for sodium cyclamate; $220 \mathrm{~nm}$ for sodium saccharin, sodium benzoate and potassium sorbate; $450 \mathrm{~nm}$ for tartrazine and sunset yellow. Mobile phase was phosphate buffer $\mathrm{pH} 4.5$ and methanol 75: $25(\mathrm{v} / \mathrm{v})$, flow rate was $1.0 \mathrm{ml} / \mathrm{min}$, column temperature was $30^{\circ} \mathrm{C}$. The range of retention time was 0.941 minute -8.583 minute. The results of validation method showed that the ranges of linearity, limit of detection, limit of quantitation, accuracy, percent RSD of the repeatability and reproducibility methods were 0.99945 - 0.99999; $0.03634 \mathrm{ppm}-2.66306 \mathrm{ppm} ; 0.12113 \mathrm{ppm}$ $8.87687 \mathrm{ppm} ; 92.92 \%-105.72 \% ; 0.11 \%-1.53 \%$ and $0.04 \%-1.94 \%$, respectively. The selectivity test of methods showed good results. The result showed that potassium sorbate is not contained in essence syrup samples. The ranges of levels of sodium saccharin, sodium cyclamate, sodium benzoate, tartrazine and sunset yellow in the samples of essences syrup were $37.952 \mathrm{mg} / \mathrm{kg}$ $533.990 \mathrm{mg} / \mathrm{kg} ; 2753.140 \mathrm{mg} / \mathrm{kg}-5329.890 \mathrm{mg} / \mathrm{kg} ; 464.456 \mathrm{mg} / \mathrm{kg}-1615.360$ $\mathrm{mg} / \mathrm{kg} ; 41.957 \mathrm{mg} / \mathrm{kg}-108.048 \mathrm{mg} / \mathrm{kg}$ and $31.084 \mathrm{mg} / \mathrm{kg}-145.399 \mathrm{mg} / \mathrm{kg}$, respectively. Samples of essences syrup contain of sodium saccharin for the I code and sodium benzoate for the $\mathrm{H}, \mathrm{J}$ and $\mathrm{K}$ codes exceed the maximum usage limit. All samples syrup contain of sodium cyclamate essences exceed the maximum usage limit.
\end{abstract}

Keywords: Sweeteners, Preservatives, Dyes, High Performance Liquid Chromatography, Optimization, Validation, Essence Syrup. 


\section{DAFTAR ISI}

Halaman

HALAM AN JUDUL ............................................................... i

LEMBAR PERSETUJUAN TESIS …................................................. iii

LEMBAR PENGESAHAN TESIS ....................................................... iv

SURAT PERNYATAAN ..............................................................

KATA PENGANTAR ................................................................... vi

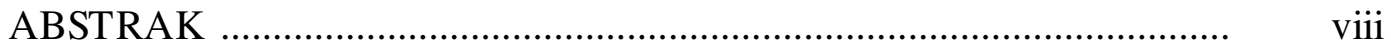

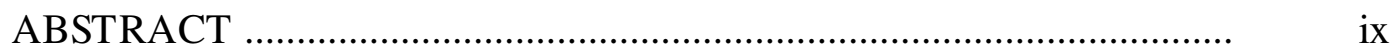

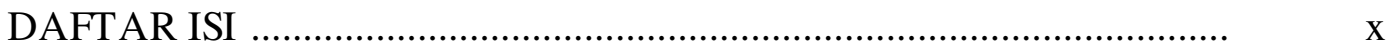

DAFT AR TABEL …...........................................................................

DAFTAR GAMBAR …........................................................... xvi

DAFTAR LAMPIRAN …........................................................... xviii

BAB I PENDAHULUAN ..............................................................

1.1 Latar Belakang ...........................................................

1.2 Kerangka Konsep Penelitian .............................................

1.3 Perumusan Masalah ......................................................... 5

1.4 Hipotesis . ..............................................................

1.5 Tujuan Penelitian ............................................................

1.6 Manfaat Penelitian ......................................................... 6

BAB II TINJAUAN PUSTAKA _.......................................................

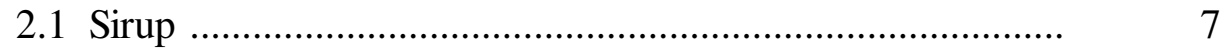

2.2 Bahan Tambahan Pangan ............................................. 8 
2.2.1 Bahan Pemanis Pangan

2.2.1.1 Sakar in

2.2.1.2 Siklamat

2.2.2 Bahan Pen gawet Pangan ........................................ $\quad 10$

2.2.2.1 Natrium Benzoat ......................................... 11

2.2.2.2 Kalium Sorbat ............................................. 12

2.2.3 Bahan Pewarna Pangan .............................................. 13

2.2.3.1 Tartrazin .....................................................

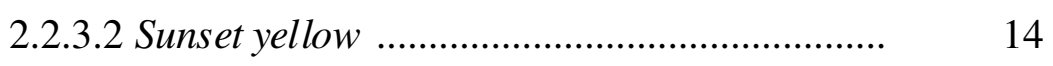

2.3 Kromatografi ........................................................ 15

2.3.1 Kromatografi Cair Kinerja Tinggi ............................

2.3.2 Komponen Kromatografi Cair Kin erja Tinggi .......... 16

2.3.3 Klasifikasi Kromato grafi Cair Kinerja Tinggi .......... 21

2.3.4 Seleksi Tipe Kromatografi Cair Kinerja Tinggi ........ 22

2.3.5 Fase Gerak Kromatografi Cair Kin erja Tinggi .......... 23

2.3.6 Fase Diam Kromatografi Cair Kinerja Tinggi .......... 25

2.4 Parameter Kromatografi Cair Kinerja Tinggi .................... 25

2.4.1 Waktu Retensi .....................................................

2.4.2 Faktor Kapasitas ............................................... $\quad 26$

2.4.3 Jumlah Plat Teoritis ............................................. 27

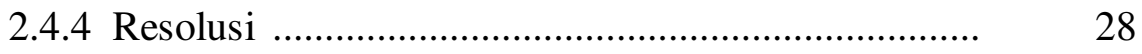

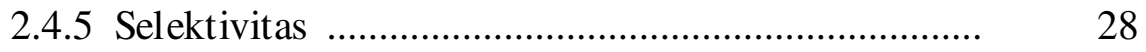

2.4.6 Faktor Tailing ...................................................... 
2.5. Validasi Metode Analisis

2.5.1 Linearitas

2.5.2 Batas Deteksi dan Batas Kuantitasi

2.5.3 Akurasi

2.5.4 Presisi

2.5.5 Selektivitas

2.6 Metode Penetapan Kadar Pemanis, Pengawet dan Pewarna

2.7 Perhitungan Kadar Pemanis, Pen gawet dan Pewarna

3.1 Metode Penelitian

3.2 Tempat dan Waktu Penelitian

3.3 Alat dan Bahan Penelitian

3.3.1 Alat Penelitian

3.3.2 Bahan Penelitian

3.4 ChamStation Software

3.5 Sampel Sirup Esens

3.6 Sirup Uji Akurasi dan Presisi

3.7 Rancangan Penelitian

3.8 Parameter Penelitian

3.9 Prosedur Penelitian

3.9.1 Pembuatan Larutan

3.9.1.1 Pembuatan Larutan Asam Fosfat $10 \mathrm{mM}$....

3.9.1.2 Pembuatan Larutan Buffer Fosfat $\mathrm{pH} 4,7$...

3.9.1.3 Pembuatan Larutan Buffer Fosfat $\mathrm{pH} 4,5$... 
3.9.1.4 Pembuatan Larutan Buffer Fosfat $\mathrm{pH} 4,3 \ldots \quad 46$

3.9.1.5 Pembuatan Larutan Buffer Fosfat pH 4,0 ... 46

3.9.1.6 Pembuatan Larutan Baku Induk Satu ......... 46

3.9.1.7 Pembuatan Larutan Baku Induk Dua .......... 47

3.9.1.8 Pembuatan Larutan Baku Tunggal ............. 47

3.9.1.9 Pembuatan Larutan Baku Tunggal Seri ...... 47

3.9.1.10 Pembuatan Larutan Baku Campuran .......... $\quad 48$

3.9.1.11 Pembuatan Larutan Baku Campuran Seri ... $\quad 48$

3.9.2 Penentuan Panjang Gelombang Maksimum ............. $\quad 49$

3.9.3 Optimasi Metode KCKT …...................................... 49

3.9.3.1 Optimasi Volume Void ................................. 49

3.9.3.2 Optimasi Panjang Gelombang ..................... $\quad 50$

3.9.3.3 Optimasi pH Fase Gerak ........................... $\quad 50$

3.9.3.4 Optimasi Komposisi Fase Gerak ................. $\quad 51$

3.9.3.5 Optimasi Laju Alir ..................................... 51

3.9.3.6 Optimasi Suhu Kolom ................................ 52

3.9.4 Penentuan Waktu Retensi Senyawa ........................ $\quad 52$

3.9.5 Validasi Metode KCKT ......................................... 53

3.9.5.1 Linearitas ............................................... 53

3.9.5.2 Akurasi ................................................ 53

3.9.5.3 Presisi .................................................. $\quad 55$

3.9.5.4 Selektivitas ............................................. 56

3.9.6 Penetapan Kadar Pemanis, Pengawet dan Pewarna

dalam Sampel .................................................... 57

xiii 
BAB IV HASIL DAN PEMBAHASAN ............................................... 58

4.1 Panjang Gelombang Maksimum ..................................... $\quad 58$

4.2 Tahap Optimasi ............................................................. 61

4.2.1 Optimasi Volume Void ........................................... 61

4.2.2 Optimasi Panjang Gelombang ................................ 63

4.2.3 Optimasi pH Fase Gerak ....................................... 69

4.2.4 Optimasi Komposisi Fase Gerak ............................. $\quad 73$

4.2.5 Optimasi Laju Alir .............................................. $\quad 75$

4.2.6 Optimasi Suhu Kolom ....................................... 77

4.3 Hasil Optimasi ......................................................... $\quad 78$

4.4 Waktu Retensi ............................................................ $\quad 79$

4.5 Validasi Metode ........................................................... $\quad 80$

4.5.1 Linearitas Baku .................................................... $\quad 80$

4.5.2 Batas Deteksi dan Batas Kuantitasi ......................... $\quad 81$

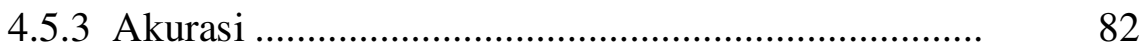

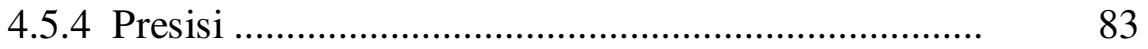

4.5.5 Selektivitas ....................................................... 84

4.6 Kadar Pemanis, Pen gawet dan Pewarna dalam Sampel ..... $\quad 86$

BAB V KESIMPULAN DAN SARAN .......................................... 92

5.1 Kesimpulan ..................................................... 92

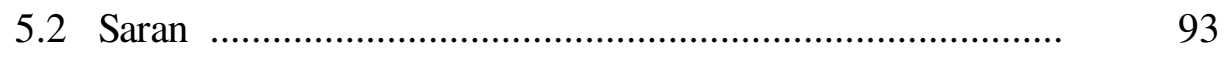

DAFTAR PUSTAKA …..................................................................... 94

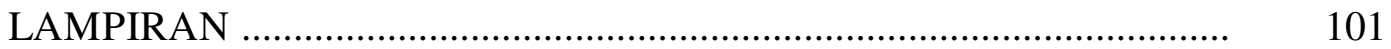




\section{DAFTAR TABEL}

Halaman

Tabel 2.1 Detektor y ang Paling Sering Digunakan pada KCKT ............. 20

Tabel 2.2 Peny ebab dan Solusi Masalah Bentuk Kromatogram ............. 30

Tabel 2.3 Rentang Persentase Recovery ................................................

Tabel 2.4 Persentase Relative Standard Deviation Uji Ripitabilitas ....... 35

Tabel 2.5 Persentase Relative Standard Deviation Uji Reproduksibilitas 35

Tabel 2.6 Daftar Beberapa Penelitian Optimasi dan Validasi metode atau Penetapan Kadar Pemanis, Pengawet dan Pewarna dengan Metode Kromatografi Cair Kin erja Tinggi ................. 38

Tabel 4.1 Pengaruh Volume Void terhadap Parameter Optimasi ............ 61

Tabel 4.2. Faktor Tailing Seny awa pada Masing-Masing Panjang Gelombang

Tabel 4.3 Pengaruh pH Buffer terhadap Parameter Optimasi ................. 69

Tabel 4.4 Pengaruh Komposisi Fase Gerak terhadap Parameter Optimasi 73

Tabel 4.5 Pengaruh Laju Alir terhadap Parameter Optimasi ................ $\quad 75$

Tabel 4.6 Pengaruh Suhu Kolom terhadap Parameter Optimasi ............ 77

Tabel 4.7 Batas Deteksi dan Batas Kuantitasi Masing-Masing Seny awa 81

Tabel 4.8 Persen Perolehan Kembali Masing-Masing Seny awa ............ $\quad 82$

Tabel 4.9 Presisi Ripitabilitas dan Reproduksibilitas Metode ................. 83

Tabel 4.10 Kadar Masing-Masing Seny awa dalam Sampel ................... $\quad 87$ 


\section{DAFTAR GAMBAR}

Halaman

Gambar 1.1 Kerangka Konsep Penelitian .............................................. 4

Gambar 2.1 Struktur Natrium Sakarin ...............................................

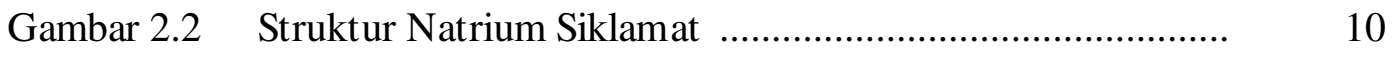

Gambar 2.3 Struktur Natrium Benzoat ............................................. 11

Gambar 2.4 Struktur Kalium Sorbat ............................................... 12

Gambar 2.5 Struktur Tartrazin ....................................................... 13

Gambar 2.6 Struktur Sunset Yellow …..................................................

Gambar 2.7 Komponen Kromatografi Cair Kin erja Tinggi ................... 16

Gambar 2.8 Skema Peny untikan Sampel Metode Valve ....................... 18

Gambar 2.9 Seleksi Tipe Kromatografi Cair Kinerja Tinggi ................ 22

Gambar 2.10 Waktu Retensi Seny awa .............................................. 26

Gambar 2.11 Resolusi Dua Seny awa _................................................... 28

Gambar 2.12 Pengukuran Faktor Tailing ............................................ 29

Gambar 4.1 Spektrum Overlay Enam Seny awa Baku ........................ 58

Gambar 4.2 Hubungan Volume Void den gan Faktor Kapasitas dan Selektifitas Natrium Sakarin, Natrium Siklamat, Natrium Benzoat, Tartrazin dan Sunset Yellow ............................... 61

Gambar 4.3 Hubungan Volume Void dengan Faktor Kapasitas dan Tailing Natium Siklamat ............................................. 62

Gambar 4.4 Kromatogram Serapan Pelarut pada Panjang Gelombang $200 \mathrm{~nm}-220 \mathrm{~nm}$

Gambar 4.5 Faktor Tailing dan Tinggi Serapan Natrium Sakarin, Natrium Benzoat dan Kalium Sorbat pada Panjang Gelombang 220 nm - 240 nm

Gambar 4.6 Kromatogram Larutan Baku Ditambah Sirup X pada Panjang Gelombang 220 nm - 240 nm 
Gambar 4.7 Kromatogram Larutan Baku Ditambah Sirup X pada

Panjang Gelombang $440 \mathrm{~nm}$ - $470 \mathrm{~nm}$

Gambar 4.8 Faktor Tailing dan Tinggi Serapan Tartrazin dan Sunset

Yellow pada Panjang Gelo mbang $440 \mathrm{~nm}-470 \mathrm{~nm}$

Gambar 4.9 Hubungan pH denga Faktor Tailing, Resolusi dan Faktor

Kapasitas Natrium Sakarin, Natrium Silkamat, Natrium

Benzoat, Kalium Sorbat, Tartrazin dan Sunset Yellow

Gambar 4.10 Pengaruh Komposisi Fase Gerak terhadap Faktor Tailing

Natrium Sakarin, Natrium Silkamat, Natrium Benzoat,

Kalium Sorbat, Tartrazin dan Sunset Yellow

Gambar 4.11 Pengaruh Laju Alir terhad ap Tekanan Pompa Sistem KCKT dan Faktor Tailing Natrium Sakarin, Natrium Silk amat, Natrium Benzoat, Kalium Sorbat, Tartrazin dan Sunset Yellow

Gambar 4.12 Kromatogram Seny awa Hasil Optimasi Metode pada Panjang Gelombang $200 \mathrm{~nm}$

Gambar 4.13 Kromatogram Seny awa Hasil Optimasi Metode pada Panjang Gelombang $220 \mathrm{~nm}$

Gambar 4.14 Kromatogram Seny awa Hasil Optimasi Metode pada Panjang Gelombang $450 \mathrm{~nm}$

Gambar 4.15 Kurva Linearitas Natrium Sakarin, Natrium Siklamat, Natrium Benzoat, Kalium Sorbat, Tartrazin dan Sunset Yellow

Gambar 4.16 Kromatogram Overlay Selektivitas Larutan Baku, Sirup X dan Sirup X Ditambah Baku pada Panjang Gelombang $200 \mathrm{~nm}$ Menggunakan Metode Hasil Optimasi

Gambar 4.17 Kromatogram Overlay Selektivitas Larutan Baku, Sirup X dan Sirup X Ditambah Baku pada Panjang Gelombang $220 \mathrm{~nm}$ Menggunakan Metode Hasil Optimasi

Gambar 4.18 Kromatogram Overlay Selektivitas Larutan Baku, Sirup X dan Sirup X Ditambah Baku pada Panjang Gelombang $450 \mathrm{~nm}$ Menggunakan Metode Hasil Optimasi

Gambar 4.19 Spektrum Overlay Natrium Sakarin Baku (Sigma Aldrich)

Gambar 4.20 Spektrum Overlay Natrium Siklamat dari Salah Satu

Produk y ang Beredar di Pasar Kota Medan

Gambar 4.21 Spektrum Overlay Natrium Siklamat Baku (Sigma Aldrich) 


\section{DAFTAR LAMPIRAN}

Halaman

Lampiran 1. Sertifikat Analisis Bahan Baku ...................................... 101

Lampiran 2. $\quad$ Spesifikasi Sampel dan Sirup X ..................................... 107

Lampiran 3. Spektrun Masing-Masing Seny awa Baku ..................... 108

Lampiran 4. Absorbansi M asing-Masing Seny awa Baku ................... 111

Lampiran 5. Kromatogram Optimasi Volume Void .......................... 112

Lampiran 6. Kromatogram Optimasi Panjang Gelombang ................ 113

Lampiran 7. Contoh Hasil Perhitungan Faktor Tailing ....................... 116

Lampiran 8. Kromatogram Optimasi pH Larutan Buffer Fosfat ......... 117

Lampiran 9. Kromatogram Optimasi Komposisi Fase Gerak …......... 121

Lampiran $10 . \quad$ Kromatogram Optimasi Laju Alir ................................ 124

Lampiran 11. Kromatogram Optimasi Suhu Kolom ............................ 127

Lampiran 12. Kromatogram Waktu Retensi Masing-Masing Seny awa Baku ............................................................................ 130

Lampiran 13. Data Waktu Retensi Masing-Masing Seny awa Baku ...... 132

Lampiran 14. Kromatogram Overlay Larutan Baku Seri ..................... 133

Lampiran 15. Massa, Konsentrasi Larutan Baku dan Data Hubungan Konsentrasi dengan Luas Area Larutan Baku Seri ......... 136

Lampiran 16. Perhitungan Batas Deteksi dan Batas Kuantitasi ........... 137

Lampiran 17. Kromatogram Akurasi ................................................. 141

Lampiran 18. Luas Area Masing-Masing Senyawa dalam Larutan Sirup X dan Sirup X Ditambah Baku .................................... 153

Lampiran 19. Contoh Perhitungan Konsentrasi Senyawa dalam Sirup X Ditambah Baku 
Lampiran 20. Contoh Perhitungan Konsentrasi Senyawa dalam Sirup X

Lampiran 21. Contoh Perhitungan Konsentrasi Sebenarny a y ang Ditambahkan ke dalam Sirup X dan Persentase Perolehan Kembali

Lampiran 22. Konsentrasi Sebenarny a y ang Ditambahkan dalam Sirup X, Konsentrasi Senyawa dalam Sirup X Ditambah Baku dan Sirup X serta Persentase Perolehan Kembali

Lampiran 23. Kromatogram Presisi

Lampiran 24. Contoh Perhitungan Standar Deviasi dan Persentase Relative Standard Deviation

Lampiran 25. Luas Area dan Hasil Perhitungan Presisi

Lampiran 26. Kromatogram Senyawa dalam Sampel

Lampiran 27. Luas Area Masing-Masing Senyawa dalam Sampel ...... 190

Lampiran 28. Contoh Perhitungan Kadar Senyawa dalam Sampel ..... 


\title{
PENGEMBA NGAN METODE PENETAPAN KADAR CAMPURAN PEMANIS, PENGAWET DAN PEWARNA SECARA SIMULTAN DALAM SIRUP ESENS DENGAN MENGGUNA KAN KROMATOGRAFI CAIR KINERJA TINGGI
}

\begin{abstract}
Abstrak
Sirup merupakan larutan gula pekat dengan atau tanpa penambahan bahan tambahan pangan. Bahan pemanis, pengawet dan pewarna dapat mengganggu kesehatan bila dikonsumsi berlebihan. Tujuan penelitian adalah untuk mengembangkan metode penetapan kadar campuran natrium sakarin, natrium siklamat, natrium benzoat, kalium sorbat, tartrazin dan sunset yellow dalam sirup esens. Penelitian menggunakan kromatografi cair kinerja tinggi fase terbalik, tiga panjang gelombang dengan instrumen UFLC 1290 DAD (Agilent), kolom C18 $100 \mathrm{~mm} \times 4,6 \mathrm{~mm} \times 3,5 \mu \mathrm{m}$ (Agilent), spektrofotometer UV Probe 1800 (Shimadzu), bahan baku natrium sakarin, natrium siklamat, natrium benzoat, kalium sorbat, tartrazin dan sunset yellow. Parameter optimasi meliputi volume void, panjang gelombang, pH fase gerak, komposisi fase gerak, laju alir dan suhu kolom. Parameter validasi meliputi linearitas, batas deteksi, batas kuantitasi, akurasi, presisi dan selektivitas. Metode yang diperoleh digunakan untuk penetapan kadar campuran natrium sakarin, natrium siklamat, natrium benzoat, kalium sorbat, tartrazin dan sunset yellow secara simultan dalam sampel sirup esens. Sebanyak enam sampel sirup esens diperoleh dari grosir dan supermarket di Kota Medan dan diberi kode $\mathrm{H}, \mathrm{I}, \mathrm{J}, \mathrm{K}, \mathrm{L}$ dan $\mathrm{M}$.

Hasil penelitian menunjukkan bahwa kondisi optimum pengujian adalah volume void $30 \%$ dengan tiga panjang gelombang analisis, yaitu: $200 \mathrm{~nm}$ untuk natrium siklamat; $220 \mathrm{~nm}$ untuk natrium sakarin, natrium benzoat dan kalium sorbat; $450 \mathrm{~nm}$ untuk tartrazin dan sunset yellow. Fase gerak buffer fosfat $\mathrm{pH} \mathrm{4,5}$ dan metanol $75: 25$ (v/v), laju alir $1,0 \mathrm{ml} / \mathrm{men}$ it, suhu kolom $30^{\circ} \mathrm{C}$. Rentang waktu retensi adalah 0,941 menit - 8,583 menit. Hasil validasi metode menunjukkan bahwa rentang linearitas, batas deteksi, batas kuantitasi, akurasi, persen RSD keterulangan dan ketertiruan metode masing-masing 0,99945 - 0,99999; 0,03634 ppm - 2,66306 ppm; 0,12113 ppm - 8,87687 ppm; 92,92\% - 105,72\%; 0,11\% $1,53 \%$ dan $0,04 \%-1,94 \%$. Uji selektivitas metode menunjukkan hasil yang baik. Hasil penelitian menunjukkan bahwa kalium sorbat tidak terkandung dalam sampel sirup esens. Rentang kadar natrium sakarin, natrium siklamat, natrium benzoat, tartrazin dan sunset yellow dalam sampel sirup esens masing-masing 37,952 mg/kg - 533,990 mg/kg; 2753,140 mg/kg - 5329,890 mg/kg; 464,456 mg/kg - 1615,360 $\mathrm{mg} / \mathrm{kg} ; 41,957 \mathrm{mg} / \mathrm{kg}-108,048 \mathrm{mg} / \mathrm{kg}$ dan $31,084 \mathrm{mg} / \mathrm{kg}-145,399 \mathrm{mg} / \mathrm{kg}$. Sampel sirup esens men gandung kad ar natrium sakarin untuk kode I dan natrium benzoat untuk kode $\mathrm{H}$, J dan K melebihi batas penggunaan maksimum. Semua sampel sirup esens mengandung natrium siklamat melebihi batas penggunaan maksimum.
\end{abstract}

Kata kunci : Pemanis, Pengawet, Pewarna, Kromatografi Cair Kinerja Tinggi, Optimasi, Validasi, Sirup Esens. 


\title{
METHOD DEVELOPMENT OF SIMULTANEOUS DETERMINATION OF SWEETENERS, PRESERVATIVES AND DYES IN ESSENCES SYRUP USING HIGH PERFORMANCE LIQUID CHROMATOGRAPHY
}

\begin{abstract}
Abt ract
Syrup is concentrated sugar solution with or without the addition of food additives. Sweeteners, preservatives and dyes can be hazardous to health if they are over consumed. The purpose of this research was to develop a method for the simultaneous determination of sodium saccharin, sodium cyclamate, sodium benzoate, potassium sorbate, tartrazine and sunset yellow in essence syrup. This research used high performance liquid chromatography reverse phase, three wavelengths with UFLC 1290 DAD (Agilent), column C18 $100 \mathrm{~mm}$ x $4.6 \mathrm{~mm} \mathrm{x}$ $3.5 \mu \mathrm{m}$ (Agilent), spectrophotometer UV Probe 1800 (Shimadzu), standard material sodium saccharin, sodium cyclamate, sodium benzoate, potassium sorbate, tartrazine and sunset yellow. Optimization parameters were include void volume, wavelengths, $\mathrm{pH}$ of mobile phase, composition of mobile phase, flow rate and column temperature. Validation parameters were include linearity, limit of detection, limit of quantitation, accuracy, precision and selectivity. The method obtained was used for the simultaneous determination of sodium saccharin, sodium cyclamate, sodium benzoate, potassium sorbate, tartrazine and sunset yellow in essence syrup samples. A total of six essence syrup samples were obtained from wholesale and supermarket in Medan City and given code H, I, J, K, L and M.

The results of reseach showed that the optimum conditions were void volume $30 \%$ with three-wavelen gth analy sis, i.e: $200 \mathrm{~nm}$ for sodium cyclamate; $220 \mathrm{~nm}$ for sodium saccharin, sodium benzoate and potassium sorbate; $450 \mathrm{~nm}$ for tartrazine and sunset yellow. Mobile phase was phosphate buffer $\mathrm{pH} 4.5$ and methanol 75: $25(\mathrm{v} / \mathrm{v})$, flow rate was $1.0 \mathrm{ml} / \mathrm{min}$, column temperature was $30^{\circ} \mathrm{C}$. The range of retention time was 0.941 minute -8.583 minute. The results of validation method showed that the ranges of linearity, limit of detection, limit of quantitation, accuracy, percent RSD of the repeatability and reproducibility methods were 0.99945 - 0.99999; $0.03634 \mathrm{ppm}-2.66306 \mathrm{ppm} ; 0.12113 \mathrm{ppm}$ $8.87687 \mathrm{ppm} ; 92.92 \%-105.72 \% ; 0.11 \%-1.53 \%$ and $0.04 \%-1.94 \%$, respectively. The selectivity test of methods showed good results. The result showed that potassium sorbate is not contained in essence syrup samples. The ranges of levels of sodium saccharin, sodium cyclamate, sodium benzoate, tartrazine and sunset yellow in the samples of essences syrup were $37.952 \mathrm{mg} / \mathrm{kg}$ $533.990 \mathrm{mg} / \mathrm{kg} ; 2753.140 \mathrm{mg} / \mathrm{kg}-5329.890 \mathrm{mg} / \mathrm{kg} ; 464.456 \mathrm{mg} / \mathrm{kg}-1615.360$ $\mathrm{mg} / \mathrm{kg} ; 41.957 \mathrm{mg} / \mathrm{kg}-108.048 \mathrm{mg} / \mathrm{kg}$ and $31.084 \mathrm{mg} / \mathrm{kg}-145.399 \mathrm{mg} / \mathrm{kg}$, respectively. Samples of essences syrup contain of sodium saccharin for the I code and sodium benzoate for the $\mathrm{H}, \mathrm{J}$ and $\mathrm{K}$ codes exceed the maximum usage limit. All samples syrup contain of sodium cyclamate essences exceed the maximum usage limit.
\end{abstract}

Keywords: Sweeteners, Preservatives, Dyes, High Performance Liquid Chromatography, Optimization, Validation, Essence Syrup. 


\section{BAB I \\ PENDAHULUAN}

\subsection{Latar Belakang}

Menurut Standar Nasional Indonesia No. 01-3544-1994 (SNI 01-35441994) yang diterbitkan oleh Badan Standarisasi Nasional (BSN), dinyatakan bahwa sirup merupakan larutan gula pekat dengan atau tanpa penambahan bahan tambahan pangan (BSN, 1994). Berdasarkan bahan baku yang digunakan untuk pembuatan sirup, maka sirup dibedakan menjadi lima, yaitu: sirup maltosa, sirup glukosa, sirup fruktosa, sirup buah dan sirup esens (BSN, 1992a; BSN, 1992b; BSN, 1992c; Satuhu, 1994). Sirup fruktosa, sirup glukosa dan sirup maltosa berdasarkan kategori pangan sebagai pemanis. Sedangkan sirup buah, sirup berperisa, squash dan squash berperisa sebagai minuman (Badan POM RI, 2006). Sirup esens adalah sirup yang cita rasanya ditentukan oleh esens yang ditambahkan, misalnya esens jeruk, esens markisa, esens nenas dan lain-lain (Satuhu, 1994).

Pemanis sintetis digunakan untuk mengontrol program pemeliharaan dan penurunan berat badan, mengurangi kerusakan gigi dan sebagai bahan substituen pemanis alami dalam diet diabetes (Roberts dan Wright, 2012; Ambarsari, dkk., 2009; Rismana dan Paryanto, 2007; Kroger, et al., 2006; BSN, 1995b; BSN, 2004). Akan tetapi, pemanis sintetis seperti sakarin dapat meningkatkan frekuensi resiko kanker kandung kemih, menimbulkan reaksi alergi dan berpotensi memicu pertumbuhan tumor (Roberts dan Wright, 2012; Ambarsari, dkk., 2009). Sik lamat menyebabkan tumor kandung kemih, paru, hati dan limpa serta menyebabkan kerusakan genetik dan atropi testicular (BSN, 2004). 
Pengawet merupakan bahan tambahan pangan untuk mencegah atau mengharnbat fermentasi, pengasaman atau peruraian terhadap makanan yang disebabkan oleh mikroorganisme (BSN, 1995a). Namun, pengawet dapat menyebabkan kerusakan organ tubuh manusia, karena pemakaian terus-menerus (Oy ewole, et al., 2012; Harmita, 2005).

Demikian juga pewarna, sebagai bahan tambahan pangan yang dapat memperbaiki atau memberi warna pada pangan, seperti tartrazin dan sunset yellow yang biasa terdapat pada sirup esens. Ternyata, tartrazin menyebabkan reaksi alergi, hiperaktif, hepatotoksik dan nefrotoksik (Rus, et al., 2010). Sunset yellow menimbulkan reaksi alergi, hiperaktivitas, sakit perut, mual dan muntah (Vachirapatama, et al., 2008). Beberapa negara membuat aturan harus menuliskan peringatan pada label tentang reaksi alergi yang mungkin terjadi (Allam dan Kumari, 2011), bahkan melarang penggunaan pewarna tartrazin dan sunset yellow (Vachirapatama, et al., 2008). Tahun 2009, European Food Safety Authority (EFSA) telah memutuskan untuk menurunkan sementara Acceptable Daily Intake (ADI) sunset yellow sebesar 2,5 $\mathrm{mg} / \mathrm{kg}$ berat badan menjadi $1 \mathrm{mg} / \mathrm{kg}$ berat badan karena alasan terjadi efek y ang signifik an pada testis (EFSA, 2009a).

Kandungan pemanis, pengawet dan pewarna dalam produk sirup esens menjadi perhatian karena dapat menimbulkan efek yang membahayakan bagi kesehatan bila dikonsumsi dalam jumlah berlebih dan jangka waktu yang lama. Oleh karena itu, dibutuhkan pengawasan untuk menjamin bahwa bahan tambahan tersebut digunakan tidak melebihi batas maksimal yang diizinkan (Badan POM RI, 2013a; Badan POM RI, 2013b; BSN, 2004). 
Kromatografi cair kinerja tinggi (KCKT) merupakan teknik analisis y ang ideal karena cepat, sederhana, kepekaan tinggi dan diperoleh hasil yang teliti (Hartono, 2007; De Lux, 2004). Penetapan kadar sakarin dalam campuran atau siklamat sebagai zat tunggal telah dilakukan dengan menggunakan KCKT (Ree dan Stoa, 2011; Novelina, dkk., 2009). Penetapan kadar natrium benzoat dan kalium sorbat juga telah dilakukan dengan menggunakan KCKT (Pylypiw dan Grether, 2000). Demikian juga penetapan kadar tartrazin dan sunset yellow, telah dilakukan dengan menggunakan KCKT (Diacu dan Ene, 2009).

Penetapan kadar natrium sakarin, natrium sik lamat, natrium benzoat, kalium sorbat, tartrazin dan sunset yellow secara simultan dapat dilakukan menggunakan KCKT. Bahan-bahan tersebut memiliki sifat fisika kimia yang beragam seperti polaritas, pKa dan panjang gelombang maksimum yang berbeda sehingga membutuhkan tahap optimasi untuk dapat dianalisis secara simultan. Metode analisis yang ada biasanya hanya menetapkan kadar satu senyawa atau beberapa senyawa dan tidak untuk menetapkan kadar keenam senyawa tersebut secara simultan.

Metode penetapan kadar yang tidak simultan menyebabkan proses pengujian menjadi tidak efisien, lebih mahal dan pereaksi kimia yang lebih banyak serta membutuhkan waktu analisis yang lebih lama. Upaya untuk memperoleh suatu metode yang baik memerlukan tahap optimasi agar diperoleh metode analisis yang memiliki resolusi yang baik, sensitifitas uji yang tinggi, waktu analisis yang cepat dan biay a y ang lebih murah (Hay un, dkk., 2004).

Oleh karena itu, penulis ingin melakukan pengembangan metode KCKT untuk menetapkan kadar campuran pemanis, pengawet dan pewarna dalam sirup esens y ang terdiri dari natrium sakarin, natrium siklamat, natrium benzoat, kalium sorbat, tartrazin dan sunset yellow. 


\subsection{Kerangka Konsep Penelitian}

Kerangka konsep penelitian terdiri dari tahap optimasi, validasi dan penetapan kadar sampel. Pada tahap optimasi terdapat dua variabel, y aitu: variabel bebas dan variabel terikat. Sebagai variabel bebas adalah volume void, panjang gelombang, pH fase gerak, komposisi fase gerak, laju alir dan suhu kolom. Sedangkan variabel terikat adalah faktor kapasitas, faktor tailing, waktu retensi, resolusi, selektivitas dan jumlah plat teoritis. Metode yang diperoleh dari hasil optimasi kemudian diuji penggunaannya sesuai parameter validasi. Metode hasil validasi kemudian digunakan untuk penetapan kadar bahan pemanis, pengawet dan pewarna dalam sampel sirup esens. Kerangka konsep penelitian dapat dilihat pada Gambar 1.1.

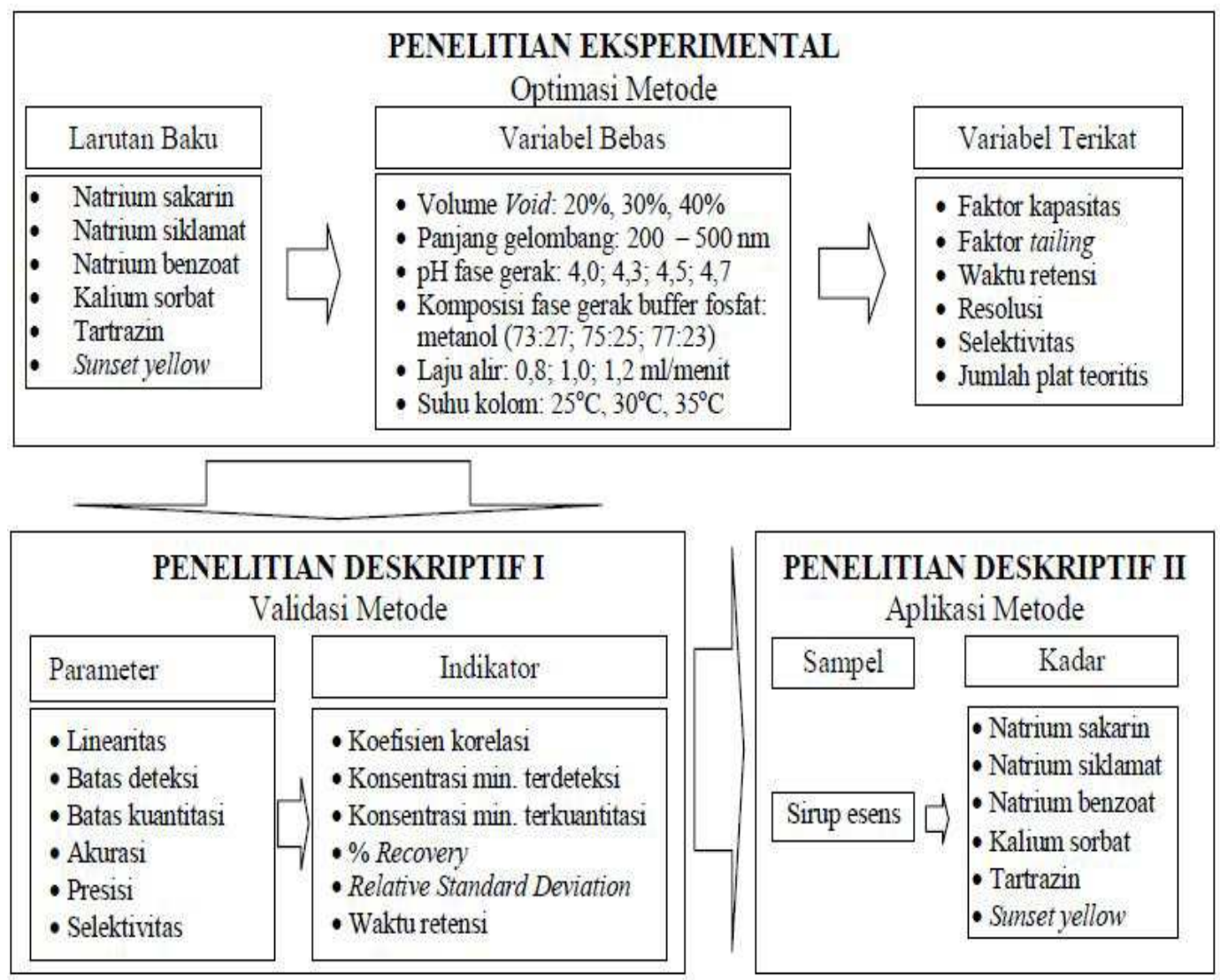

Gambar 1.1 Kerangka Konsep Penelitian 


\subsection{Perumusan Masalah}

Berdasarkan kerangka konsep penelitian, dapat disusun rumusan masalah sebagai berikut:

1. Apakah pengembangan metode penetapan kadar campuran natrium sakarin, natrium siklamat, natrium benzoat, kalium sorbat, tartrazin dan sunset yellow secara simultan dengan menggunakan Kromatografi Cair Kinerja Tinggi memberikan hasil kondisi KCKT y ang optimum?

2. Apakah hasil optimasi pengembangan metode penetapan kadar campuran natrium sakarin, natrium siklamat, natrium benzoat, kalium sorbat, tartrazin dan sunset yellow secara simultan dengan menggunakan Kromatografi Cair Kinerja Tinggi memenuhi syarat validasi?

3. Apakah hasil validasi pengembangan metode penetapan kadar campuran natrium sakarin, natrium siklamat, natrium benzoat, kalium sorbat, tartrazin dan sunset yellow secara simultan dengan menggunakan Kromatografi Cair Kinerja Tinggi dapat diaplikasikan untuk menentukan kadar campuran natrium sakarin, natrium siklamat, natrium benzoat, kalium sorbat, tartrazin dan sunset yellow secara simultan dalam sirup esens?

\subsection{Hipotesis}

Berdasarkan perumusan masalah di atas, maka hipotesis dari penelitian ini adalah:

1. Pengembangan metode penetapan kadar campuran natrium sakarin, natrium siklamat, natrium benzoat, kalium sorbat, tartrazin dan sunset yellow secara simultan dengan menggunakan Kromatografi Cair Kinerja Tinggi memberikan hasil kondisi KCKT y ang optimum berdasarkan parameter optimasi. 
2. Hasil optimasi pengembangan metode penetapan kadar campuran natrium sakarin, natrium siklamat, natrium benzoat, kalium sorbat, tartrazin dan sunset yellow secara simultan dengan menggunakan Kromatografi Cair Kinerja Tinggi memenuhi persy aratan validasi.

3. Hasil validasi pengembangan metode penetapan kadar campuran natrium sakarin, natrium siklamat, natrium benzoat, kalium sorbat, tartrazin dan sunset yellow secara simultan dengan menggunakan Kromatografi Cair Kinerja Tinggi dapat diaplikasikan untuk menetapkan kadar campuran natrium sakarin, natrium siklamat, natrium benzoat, kalium sorbat, tartrazin, sunset yellow secara simultan dalam sirup esens.

\subsection{Tujuan Penelitian}

Tujuan dari penelitian ini adalah mengembangkan metode KCKT dioda array untuk digunakan dalam penetapan kadar campuran natrium sakarin, natrium siklamat, natrium benzoat, kalium sorbat, tartrazin dan sunset yellow secara simultan dalam sirup esens.

\subsection{Manfaat Penelitian}

Hasil penelitian diharapkan menjadi metode pilihan utama yang dapat digunakan oleh Badan POM RI dan Laboratorium Standarisasi serta menjadi rujukan metode penetapan kadar natrium sakarin, natrium siklamat, natrium benzoat, kalium sorbat, tartrazin dan sunset yellow secara simultan dalam sirup esens yang beredar di pasaran. 


\section{BAB II}

\section{TI NJA UA N PUSTAKA}

\subsection{Sirup}

Sirup adalah larutan gula pekat dengan atau tanpa penambahan bahan tambahan pangan yang diizinkan (BSN, 1994). Berdasarkan bahan baku yang digunakan untuk pembuatan sirup, maka sirup dibedakan menjadi lima, yaitu: sirup maltosa, sirup glukosa, sirup fruktosa, sirup buah dan sirup esens (BSN, 1992a; BSN, 1992b; BSN, 1992c; Satuhu, 1994). Berdasarkan kategori pangan sirup fruktosa, glukosa dan maltosa sebagai pemanis. Sedangkan sirup buah, berperisa, squash dan squash berperisa sebagai minuman (Badan POM RI, 2006).

Sirup glukosa, fruktosa atau maltosa merupakan cairan kental dan jernih dengan komponen utama glukosa, fruktosa atau maltosa yang diperoleh dari hidrolisis pati dengan cara kimia atau enzematis (BSN, 1992a; BSN, 1992b; BSN, 1992c). Sirup buah atau minuman squash adalah sirup yang aroma dan rasanya ditentukan oleh buah segar (BSN, 1998; Satuhu, 1994). Sirup buah atau squash adalah produk minuman yang cita rasanya ditentukan oleh sari buah yang ditambahkan (Badan POM RI, 2006; BSN, 1998; Satuhu, 1994). Sirup esens atau sirup berperisa adalah produk minuman yang cita rasany a ditentukan oleh esens y ang ditambahkan misalnya: esens jeruk, mangga, markisa atau nenas dan lainlain (Badan POM RI, 2006; Satuhu, 1994). Squash berperisa adalah produk minuman y ang cita rasany a ditentukan oleh esens dengan atau tanpa cita rasa buah (Badan POM RI, 2006). 


\subsection{Bahan Tambahan Pangan}

Bahan tambahan pangan (BTP) adalah bahan yang ditambahkan ke dalam pangan untuk mempen garuhi sifat atau bentuk pangan, baik y ang mempunyai atau tidak mempunyai nilai gizi (BSN, 2004). BTP merupakan bahan yang ditambahkan dengan sengaja ke dalam produk pangan dalam jumlah kecil den gan tujuan untuk memperbaiki penampilan, cita rasa, memperpanjang daya simpan dan lain-lain (B SN, 1995a).

Bahan tambahan pangan bukan bagian dari bahan pangan, tetapi terdapat dalam produk pangan tersebut karena perlakuan saat pengolahan, penyimpanan atau pengemasan. BTP meliputi bahan pengawet, pemanis, pewarna, penguat rasa, pemutih, anti kempal dan anti oksidan (BSN, 1995a). Batas penggunaan maksimum atau konsentrasi maksimum yang diizinkan untuk ditambahkan ke dalam produk pangan dinyatakan dalam milligram per kilogram bahan sesuai dengan nomor kategori pangan (Badan POM RI, 2006; BSN, 2004).

\subsubsection{Bahan Pemanis Pangan}

Pemanis sintetis adalah bahan tambahan pangan yang dapat menyebabkan terutama rasa manis pada produk pangan dengan tidak atau sedikit mempunyai nilai gizi atau kalori. Pemanis sintetis y ang diizinkan mencakup alitam, asesulfam, aspartam, isomalt, laktitol, maltitol, manitol, neotam, sakarin, siklamat, silitol, sorbitol dan sukralosa (BSN, 2004). Pemanis sintetis dapat ditemukan hampir pada semua produk, seperti: yoghurt, es krim, makanan pencuci mulut, permen, permen karet, saus dan produk lainny a (Zy gler, et al., 2011). 


\subsubsection{Sakarin}

Sakarin atau 1,2-benzisotiazolin-3-on-1,1-dioksida dengan rumus kimia $\mathrm{C}_{7} \mathrm{H}_{5} \mathrm{NO}_{3} \mathrm{~S}$, mempunyai pKa 1,8 dan panjang gelombang maksimum $202 \mathrm{~nm}$, secara komersil dalam bentuk garam kalsium, kalium dan natrium (Ambarsari, dkk., 2009; Windholz, et al., 1983). Garam sakarin berbentuk kristal putih, tidak berbau, mudah larut dalam air dan berasa manis dengan tingkat kemanisan relatif sebesar 300 sampai 500 kali kemanisan sukrosa, tetapi tanpa nilai kalori (Serdar dan Knezevic, 2011). Struktur natrium sakarin dapat dilihat pada Gambar 2.1 (Windholz, et al., 1983; Kroger, 2006).<smiles>NN1C(=O)c2ccccc2S1(=O)=O</smiles>

\section{Gambar 2.1 Struktur Natrium Sakarin}

Sakarin tidak dimetabolisme, lambat diserap oleh usus, cepat dikeluarkan melalui urin tanpa perubahan, tidak bereaksi dengan DNA, tidak bersifat karsinogenik, tidak menyebabkan karies gigi dan cocok bagi penderita diabetes (Ambarsari, dkk., 2009). Meskipun dinyatakan aman untuk dikonsumsi, namun penggunaan dalam produk pangan di USA masih dibatasi (Kroger, et al., 2006). Mungkin, karena tikus yang diberi sakarin $0,5 \%$ setiap hari selama dua tahun terbukti menderita kanker kandung kemih (Reuber, 1978). Joint FAO/WHO Expert Committee on Food Additives (JECFA) menetapkan ADI untuk sakarin sebesar $5 \mathrm{mg} / \mathrm{kg}$ bb/hari (BSN, 2004). Penggunaan pada sirup esens tidak lebih dari 500 mg/kg (B SN, 2004). 


\subsubsection{Siklamat}

Siklamat, asam siklamat atau asam sikloheksilsulfamat $\left(\mathrm{C}_{6} \mathrm{H}_{13} \mathrm{NO}_{3} \mathrm{~S}\right)$ (Ambarsari, dkk., 2009), mempunyai pKa 1,90 dan panjang gelombang maksimum $194 \mathrm{~nm}$ (Xiao, et al., 2011). Siklamat digunakan dalam bentuk garam kalsium, kalium dan natrium. Garam siklamat berbentuk kristal putih, tidak berbau, tidak berwarna, mudah larut dalam air dan etanol, berasa manis (Ambarsari, dkk., 2009). Struktur natrium siklamat dapat dilihat pada Gambar 2.2 (Windholz, et al., 1983).

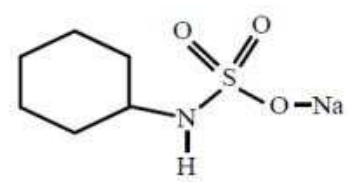

Gambar 2.2 Struktur Natrium Siklamat

Siklamat memiliki kemanisan relatif sebesar 30 kali kemanisan sukrosa dan tanpa nilai kalori. Kombinasi dengan sakarin bersifat sinergis. JECFA menetapkan acceptable daily intake (ADI) untuk siklamat sebesar $11 \mathrm{mg} / \mathrm{kg}$ bb/hari (BSN, 2004). Penggunaan pada sirup esens tidak lebih dari $1000 \mathrm{mg} / \mathrm{kg}$ (BSN, 2004).

\subsubsection{Bahan Pengawet Pangan}

Pengawet adalah bahan tambahan pangan untuk mencegah atau menghambat fermentasi terhadap pangan yang disebabkan oleh mikroorganisme. Pengawet yang diizinkan antara lain: asam atau garam benzoat, propanoat dan sorbat (Badan POM RI, 2013a). 


\subsubsection{Natrium Benzoat}

Asam benzoat atau acidum benzoicum berfungsi sebagai antimikroba, mempunyai pKa 4,2 dan panjang gelombang maksimum $225 \mathrm{~nm}$. Natrium benzoat atau natrium benzenakarboksilat $\left(\mathrm{C}_{6} \mathrm{H}_{5} \mathrm{COONa}\right)$ yang sering digunakan sebagai pen gawet karena san gat mudah larut dalam air, berupa serbuk y ang stabil, tidak berbau, berwarna putih dengan rasa menyengat, bersifat higroskopik dan larut dalam metanol (Windholz, et al., 1983; Pylypiw dan Grether, 2000). Struktur natrium benzoat dapat dilihat pada Gambar 2.3 (Windholz, et al., 1983).

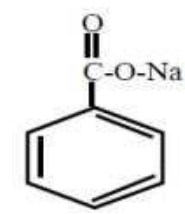

\section{Gambar 2.3 Struktur Natrium Benzoat}

Natrium benzoat digunakan pada makanan yang mempunyai $\mathrm{pH}$ 2,5 - 4,0 untuk menghambat pertumbuhan mikroorganisme, misalnya: minuman berkarbonasi, selai, jus buah dan sirup (Oyewole, et al., 2012; Sibarani, 2010; Hartono, 2007; Pylypiw dan Grether, 2000). Penggunaan pada sirup tidak lebih dari 0,09\% atau $900 \mathrm{ppm}$ (Badan POM RI, 2013a) dengan ADI sebesar $5 \mathrm{mg} / \mathrm{kg}$ berat badan (JECFA, 1974). Natrium benzoat telah dilaporkan meny ebabkan efek samping langsung, seperti reaksi alergi (Hussain, et al., 2011) atau efek samping tidak langsung yang serius dalam tubuh akibat dikonsumsi secara terus-menerus sehingga menyebabkan kerusakan sel hati dan ginjal yang ditandai dengan peningkatan aspartate aminotransferase (AST), alanine aminotransferase (ALT) dalam serum dan kreatinin, glutamin, urea dan asam urat dalam urin (Oyewole, et al., 2012). 


\subsubsection{Kalium Sorbat}

Asam sorbat atau asam-trans-2,4-hexadienat memiliki rumus molekul $\mathrm{C}_{6} \mathrm{H}_{8} \mathrm{O}_{2}$. Asam sorbat merupakan padatan putih berbentuk kristal dan berbau agak asam. Asam sorbat efektif untuk mencegah pertumbuhan khamir, kapang dan bakteri pada pH rendah, namun tetap efisien pada pH 6,5 (Hussain, et al., 2010; Pylypiw dan Grether, 2000; Windholz, et al., 1983).

Secara komersil, asam sorbat tersedia dalam bentuk garam kalsium, natrium, dan kalium sorbat. Kalium sorbat lebih umum digunakan daripada asam sorbat karena kelarutan dalam air lebih tinggi daripada asam sorbat, mempunyai $\mathrm{pKa}$ 4,80 dan panjang gelombang maksimum $255 \mathrm{~nm}$ (Hussain, et al., 2010; Pylypiw dan Grether, 2000; Windholz, et al., 1983). Struktur kalium sorbat dapat dilihat pada Gambar 2.4 (Windholz, et al., 1983).<smiles>[X]OC(=O)/C=C\C=C/C</smiles>

Gambar 2.4 Struktur Kalium Sorbat

Kalium sorbat telah digunakan sebagai pengawet sejak tahun 1945. Kalium sorbat banyak digunakan dalam berbagai macam makanan termasuk keju, roti, margarin, sayuran, produk buah, salad, sirup dan ikan asin. Konsentrasi kalium sorbat dalam sirup tidak lebih dari 0,1\% atau 1000 ppm (Hussain, et al., 2010; Sibarani, 2010; Badan POM RI, 2013a) dengan ADI sebesar 25 mg/kg bobot badan (JECFA, 1974). 


\subsubsection{Bahan Pewarna Pangan}

Pewarna adalah bahan tambahan pangan yang dapat memperbaiki atau memberi warna pada makanan. Pewarna alami dan sintetik telah banyak digunakan dalam pangan, namun $95 \%$ yang digunakan saat ini adalah sintetis, karena diproduksi dengan mudah, murah dan memberikan warna yang lebih stabil (Gautam, et al., 2010). Tartrazin dan sunset yellow merupakan pewarna sintetis y ang banyak digunakan dalam minuman ringan, sirup, biscuit, saus dan lain-lain (Gautam, et al., 2010; Vachirapatama, et al., 2008).

\subsubsection{Tartrazin}

Tartrazin atau trinatrium-5-hidroksi-1-(4-fenilsulfonat)-4-(4-fenilazosulfonat) pirazol-3-karboksilat (EFSA, 2009b), rumus molekul $\mathrm{C}_{16} \mathrm{H}_{9} \mathrm{~N}_{4} \mathrm{Na}_{3} \mathrm{O}_{9} \mathrm{~S}_{2}$ dan $\mathrm{pKa}=10,9$ (Gomez, et al., 2012; Himri, et al., 2011) dengan nomor indeks warna 19140 (Zatar, 2007). Tartrazin merupakan serbuk berwarna kuning, stabil terhadap suhu, cahaya, asam dan basa serta mempunyai panjang gelombang maksimum $427 \mathrm{~nm}$ (Zatar, 2007). Struktur tartrazin dapat dilihat pada Gambar 2.5 (Windholz, et al., 1983).

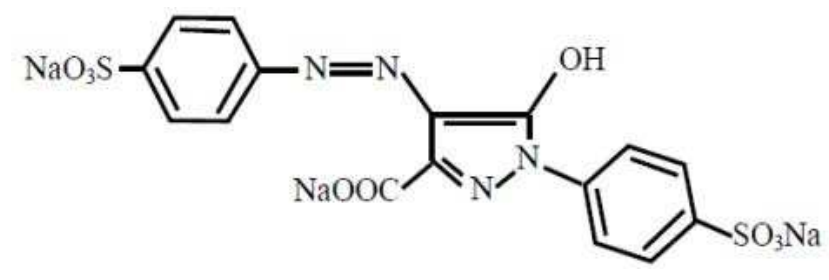

Gambar 2.5 Struktur Tartrazin

Tartrazin dikenal sebagai zat warna azo yang digunakan dalam pangan, produk obat-obatan dan kosmetik. Batasan ADI sebesar 7,5 mg/kg berat badan (EFSA, 2009b) dan batas maksimum penggunaan dalam sirup sebesar $300 \mathrm{mg} / \mathrm{kg}$ atau $0,03 \%$ (Badan POM RI, 2013b). 
Efek kronis warna ortoaminoazo-toluen dapat menyebabkan kanker hati, jika dikonsumsi dalam jangka waktu lama. Senyawa azo lainnya dapat mengakibatkan kanker dengan waktu lebih lama (Himri, et al., 2011). Pewarna tartrazin meny ebabkan hepatotoksik dan nefrotoksik (Rus, et al., 2010) sehingga Austria maupun Norwegia melarang penggunaan tartrazin (Vachirapatama, et al., 2008).

\subsubsection{Sunset Yellow}

Sunset yellow, dinatrium-6-hidroksi-5-(4-sulfonatofenilazo) naftalen sulfonat (EFSA, 2009a), nomor indeks warna 15985 (Zatar, 2007), serbuk berwarna kuning, stabil terhadap suhu, cahaya, asam dan basa, mempunyai $\mathrm{pKa}=$ 9,20 dan panjang gelombang maksimum $481 \mathrm{~nm}$ (Gomez, et al., 2012; Zatar, 2007). Struktur sunset yellow dapat dilihat pada Gambar 2.6 (Vachirapatama, et al., 2008).

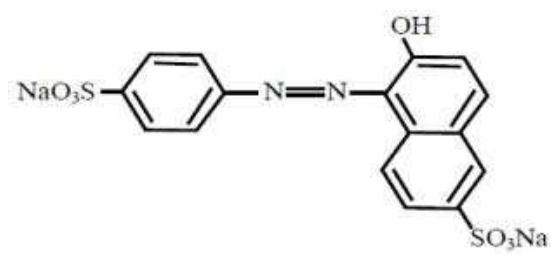

Gambar 2.6 Struktur Sunset Yellow

Sunset yellow dapat ditemukan dalam sirup orange, jus jeruk, es krim dan lain-lain (Vachirapatama, et al., 2008). Batasan ADI sebesar 2,5 mg/kg diubah sementara menjadi $1 \mathrm{mg} / \mathrm{kg}$ berat badan karena alasan terjadi efek y ang signifikan pada testis (EFSA, 2009a). Batas maksimum sunset yellow dalam sirup sebesar $300 \mathrm{mg} / \mathrm{kg}$ atau 0,03 \% (Badan POM RI, 2013b). Sunset yellow dapat menimbulkan alergi, hiperaktivitas, mual dan muntah. Norwegia melarang penggun an sunset yellow (Vachirapatama, et al., 2008; EFSA, 2009a). 


\subsection{Kromatografi}

Kromatografi pertama sekali diperkenalkan oleh Mikhail Tswett, seorang ahli botani Rusia pada tahun 1903. Beliau memisahkan pigmen yang terdapat dalam daun den gan kolom gelas vertikal y ang diisi serbuk kalsium karbonat. Pada waktu yang hampir bersamaan, D.T. Day juga menggunakan kromatografi untuk memisahkan fraksi-fraksi petroleum, namun Mikhail Tswett yang diakui sebagai penemu dan yang menjelaskan tentang proses kromatografi (Dong, 2006; De Lux, 2004; Grob dan Barry, 2004).

Kromatografi merupakan tehnik pemisahan campuran menggunakan fase diam dan fase gerak. Fase gerak mengalir melalui fase diam dan membawa komponen-komponen campuran dengan laju yang berbeda, sehingga terjadi pemisahan karena pembedaan daya adsorpsi, partisi, kelarutan, tekanan uap, ukuran molekul atau muatan ion. Berdasarkan fase gerak, kromatografi dikelompokkan menjadi dua jenis, yaitu: Kromatografi Gas dan Kromatografi Cair. Kromatografi Cair Kinerja Tinggi merupakan salah satu jenis Kromatografi Cair (Dong, 2006; De Lux, 2004; Grob dan B arry, 2004).

\subsubsection{Kromatografi Cair Kinerja Tinggi}

Kromatografi Cair Kinerja Tinggi (KCKT) adalah metode kromatografi y ang menggunak an fase gerak cair dan fase diam cair atau padat untuk melakukan pemisahan suatu jenis molekul. KCKT yang menggunakan fase gerak polar dengan fase diam non-polar disebut KCKT fase terbalik (reversed phase). KCKT y ang menggunakan fase gerak non-polar dan fase diam polar disebut KCKT fase normal (normal phase) (De Lux, 2004; Gritter, et al.,1991). 


\subsubsection{Komponen Kromatografi Cair Kinerja Tinggi}

Komponen Kromatografi Cair Kinerja Tinggi dapat dilihat pada Gambar 2.7 y ang terdiri dari:

1. Wadah fase gerak

Wadah fase gerak terbuat dari bahan yang inert terhadap fase gerak. B ahan y ang umum digunakan adalah gelas dan baja anti karat. Daya tampung tandon harus lebih besar dari $500 \mathrm{ml}$ sehingga dapat digunakan selama 4 jam dengan kecepatan alir y ang umumny a 1-2 ml/menit (Dong, 2006; De Lux, 2004).

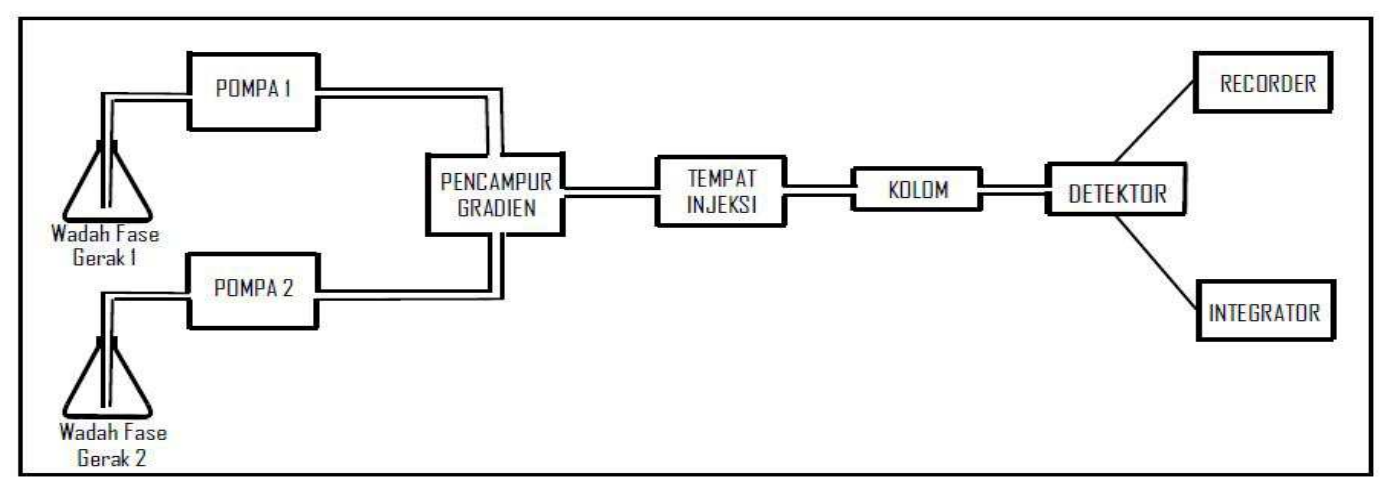

Sumber: De Lux, 2004

Gambar 2.7 Komponen Kromatografi Cair Kinerja Tinggi (KCKT)

\section{Pompa}

Untuk mengalirkan fase gerak melalui kolom diperlukan pompa yang terbuat dari bahan inert terhadap semua pelarut, umumnya digunakan gelas, baja antikarat dan teflon. Aliran pelarut harus tanpa denyut untuk menghindari hasil y ang meny impang pada detektor. Pompa harus men ghasilkan tekanan sampai 600 psi dengan kecepatan alir berkisar 0,1 - $10 \mathrm{ml} / \mathrm{menit}$. Ada tiga jenis pompa yang masing-masing memiliki keuntungan dan kerugian, yaitu (De Lux, 2004; Sny der dan Kirkland, 1979): 


\section{a. Pompa Reciprocating}

Jenis pompa reciprocating paling banyak digunakan, namun menghasilkan pulsa yang dapat mengganggu base-line kromatogram sehingga dipasang peredam. Keuntungan menggunakan pompa reciprocating adalah pompa memiliki volume internal yang kecil sehingga mengurangi band broadening. Selain itu, pompa menghasilkan tekanan tinggi, kecepatan alir konstan yang tidak bergantung pada tekanan balik kolomdan viskositas pelarut.

b. Pompadisplacement

Pompa ini menyerupai syringe yang terdiri dari tabung dengan dilengkapi pendorong dan digerakkan oleh motor. Pompa tidak menghasilkan pulsa dengan alir an y ang cenderung tidak bergantung pada tekanan balik kolom dan viskositas pelarut. Akan tetapi, pompa mempunyai keterbatasan kapasitas pelarut dan tidak mudah untuk melakuk an pergantian pelarut.

\section{c. Pompa pneumatic}

Pelarut dalam pompa didorong oleh gas bertekanan tinggi. Pompajenis pneumatic harganya murah dan bebas pulsa. Akan tetapi, pompa mempunyai keterbatasan kapasitas dan tekanan yang dihasilkan serta kecepatan alir bergantung pada viskositas pelarut dan tekanan balik kolom.

\section{Injektor}

Injektor sebagai tempat memasukkan sampel dan kemudian sampel dapat didistribusikan masuk ke dalam kolom. Sampel cair dan larutan disuntikkan secara langsung ke dalam fase gerak yang mengalir di bawah tekanan menuju kolom menggunakan alat penyuntik yang terbuat dari tembaga tahan karat dan katup teflon yang dilengkapi dengan kantong sampel (sample loop) internal atau 
eksternal. Ada dua model umum injeksi sampel, yaitu Stopped Flow (fase gerak dihentikan sesaat) dan Solvent Flowing (fase gerak tetap mengalir) dengan tiga dasar cara menginjeksikan sampel, yaitu (Varelis, 2008; Dong, 2006; De Lux, 2004; Sny der dan Kirkland, 1979):

a. Stop Flow: menghentikan aliran fase gerak saat injeksi sampel dilakukan, sistem tertutup, kemudian aliran dilanjutkan lagi. Teknik ini bisa digunakan karena difusi di dalam aliran kecil dan resolusi tidak dipengaruhi.

b. Septum: menginjeksikan sampel langsung ke aliran fase gerak, umumnya sama den gan y ang digunakan pada kromatografi gas. Injektor dapat digunakan pada tekanan sampai 60 - 70 atmosfir, tetapi septum ini tidak tahan terhadap pelarut kromatografi cair. Di samping itu, partikel kecil dari septum yang terkoy ak dapat meny ebabkan peny umbatan.

c. Valve: menginjeksikan sampel ke dalam aliran fasa gerak dilakukan dengan dua lan gkah, y aitu:

1. Sejumlah volume sampel diinjeksikan ke dalam loop dalam posisi load.

2. Kran diputar untuk mengubah posisi load menjadi posisi injeksi dan fasa gerak membawa cuplikan ke dalam kolom.

Dengan sistem ini memungkinkan sampel dimasukkan pada tekanan 7000 psi dengan ketelitian tinggi. Skema penyuntikan sampel dengan metode valve dapat dilihat pada Gambar 2.8.

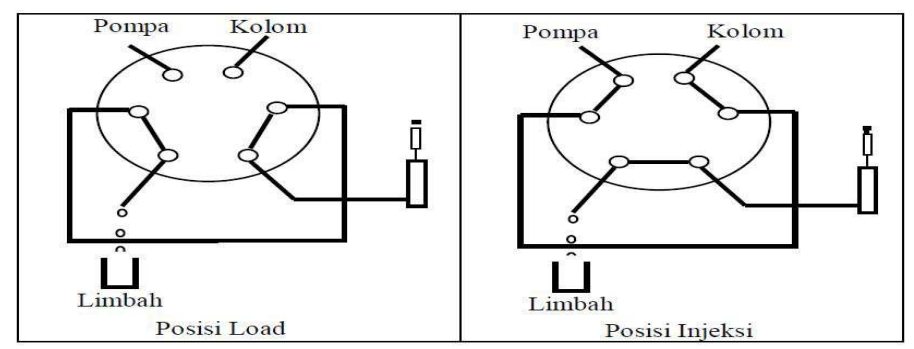

Gambar 2.8 Skema Peny untikan Sampel Metode Valve 
4. Kolom

Kolom merupakan tempat fase diam untuk berlangsungnya proses pemisahan dan dibagi menjadi dua kelompok, yaitu (Varelis, 2008; Dong, 2006; De Lux, 2004; Sny der dan Kirkland, 1979):

a. Kolom analitik: memiliki diameter $2-6 \mathrm{~mm}$ dan panjang kolom tergantung pada jenis kemasan. Panjang kolom untuk kemasan poros makropartikel (37 $44 \mu)$ adalah $50-100 \mathrm{~cm}$ dan untuk kemasan poros mikropartikel $(<20 \mu)$ pada umumnya $10-30 \mathrm{~cm}$.

b. Kolom preparatif: memiliki diameter $\geq 6 \mathrm{~mm}$ dan panjang $25-100 \mathrm{~cm}$.

\section{Detektor}

Detektor dibutuhkan untuk mendeteksi komponen sampel dalam aliran yang keluar dari kolom. Detektor pada KCKT dikelompokkan menjadi 2 golongan, yaitu (Varelis, 2008; Dong, 2006; De Lux, 2004; Sny der dan Kirkland, 1979):

a. Detektor universal, detektor y ang mampu mendeteksi zat secara umum, tidak bersifat spesifik dan tidak bersifat selektif, seperti: detektor indeks bias dan detektor spektrometri massa.

b. Detektor spesifik, detektor y ang hanya mendeteksi senyawa secara spesifik dan selektif, seperti detektor UV-Vis, detektor fluoresensi dan elektrokimia.

Detektor yang ideal harus mempunyai karakteristik sebagai berikut (De Lux, 2004; Gritter, et al., 1991; Sny der dan Kirkland, 1979):

a. San gat sensitif dan memberi respon y ang cepat untuk semua zat terlarut.

b. Stabil, tidak dipengaruhi oleh perubahan suhu dan kecepatan alir fase gerak. 
c. Mempuny ai sel volume y ang kecil sehingga mampu meminimalk an broading.

d. Memberikan respon yang linear terhadap konsentrasi zat terlarut dan inert terhadap zat terlarut.

Detektor yang digunakan dalam KCKT dapat diterapkan untuk analisis senyawa dalam makanan. Detektor yang paling sering digunakan pada KCKT dapat dilihat pada Tabel 2.1. Kemampuan detektor UV untuk mengkonfirmasi adanya senyawa tertentu, metabolit dan turunannya dalam sampel sangat baik sehingga detektor UV paling populer. Namun, untuk analisis y ang membutuhkan sensitivitas dan selektivitas yang tinggi digunakan detektor fluoresensi sebagai metode pilihan. Meskipun detektor elektrokimia juga san gat sensitif dan selektif, tetapi jarang digunakan dalam analisis makanan. Sedangkan detektor konduktivitas merupakan detektor yang sensitif dan selektif untuk analisis kation dan anion. Detektor indeks bias digunakan jika detektor yang lain tidak sesuai atau konsentrasi senyawa dalam sampel tinggi (Dong, 2006; Angelika, et al., 2001; Sny der dan Kirkland, 1979).

Tabel 2.1 Detektor y ang Paling Sering Digunakan pada KCKT

\begin{tabular}{|l|c|l|}
\hline \multicolumn{1}{|c|}{ Detektor } & Sensitivitas (g/ml) & \multicolumn{1}{c|}{ Karakteristik } \\
\hline UV & $2 \times 10^{-10}$ & $\begin{array}{l}\text { Sensitif, paling sering digunakan. Tidak peka terhadap } \\
\text { perubahan suhu dan kecepatan alir fase gerak. Selektif } \\
\text { terhadap gugus dan struktur tidak jenuh. }\end{array}$ \\
\hline Fluoresensi & $1 \times 10^{-12}$ & $\begin{array}{l}\text { Sensitif. Tidak peka terhadap perubah an suhu dan } \\
\text { kecepatan alir fas gerak. Selektif bagi senyawa } \\
\text { berflouresensi. }\end{array}$ \\
\hline $\begin{array}{l}\text { Refraksi } \\
\text { Indeks }\end{array}$ & $1 \times 10^{-7}$ & $\begin{array}{l}\text { Universal. Sensitif terhadap suhu dan tidak dapat } \\
\text { digunakan pada elusi gradien. Dapat digunak untuk } \\
\text { mendeteksi polimer, gula, trigliserida, asam organik. }\end{array}$ \\
\hline Elektrokimia & $1 \times 10^{-12}$ & $\begin{array}{l}\text { Sensitif terhadap suhu dan kecepatan alir fase gerak, } \\
\text { tidak dapat digunakan pada elusi gradien. Selektif } \\
\text { terhadap oksidator-reduktor. }\end{array}$ \\
\hline Konduktimetri & $\begin{array}{l}\text { Sensitif terhadap suhu dan kecepatan alir fase gerak, } \\
\text { tidak dapat digunakan pada elusi gradien. Selektif } \\
\text { terhadap ionik, asam organik dan surfaktan. }\end{array}$ \\
\hline
\end{tabular}

Sumber: Dong, 2006; Angelika, et al., 2001; Snyder dan Kirkland, 1979. 


\section{Integrator}

Integrator adalah alat yang mengubah tanda-tanda listrik dari detektor menjadi kromatogram sekaligus menghitung luas kromatogram yang dibentuk secara elektronik (Dong, 2006; De Lux, 2004; Sny der dan Kirkland, 1979).

7. Rekorder

Hasil pemisahan kromatografi biasanya ditampilkan dalam bentuk kromatogram pada rekorder. Waktu retensi selalu konstan dari setiap kondisi kromatografi yang sama dan dapat digunakan untuk identifikasi atau analisis kualitatif. Luas puncak proporsional dengan konsentrasi senyawa dalam sampel yang diinjeksikan sehingga dapat digunakan untuk menghitung konsentrasi senyawa dalam sampel pada analisis kuantitatif. Senyawa yang berbeda memiliki waktu retensi yang berbeda. Waktu retensi bervariasi dan tergantung pada (Dong, 2006; De Lux, 2004; Snyder dan Kirkland, 1979):

a. Panjang kolom, jenis dan ukuran partikel material fase diam.

b. Jenis, komposisi dan $\mathrm{pH}$ fase gerak.

c. Temperatur kolom, tekanan pompa dan laju alir.

\subsubsection{Klasifikasi Kromatografi Cair Kinerja Tinggi}

Pemisahan dengan KCKT dapat dilakukan dengan fase normal, jika fase diam lebih polar daripada fase gerak atau fase terbalik, jika fase diam kurang polar dibanding dengan fase gerak. Sehingga KCKT dapat dikelompokkan menjadi KCKT fase normal dan KCKT fase terbalik. Selain klasifikasi tersebut, KCKT juga dapat dikelompokkan berdasarkan mekanisme pemisahan, yaitu: kromatografi adsorbsi, kromatografi partisi, kromatografi penukar ion, kromatografi pasangan ion, kromatografi fase terikat, kromatografi eksklusi dan kromatografi afinitas (De Lux, 2004; Sny der dan Kirkland, 1979). 


\subsubsection{Seleksi Tipe Kromatografi Cair Kinerja Tinggi}

Sebelum mengoperasikan KCKT, analis harus membuat keputusan tipe kromatografi agar memberikan informasi yang diinginkan. Namun, sampel yang tidak dikenal akan menyulitkan pemilihan. Informasi kelarutan, gugus fungsi, massa molekul relatif (Mr) atau data spektroskopi seperti nucleic magnetic resonance (NMR), infra red (IR), ultra violet (UV) dan mass spektrofotometer (MS) dapat digunakan sebagai petunjuk bagi analis memilih tipe KCKT yang tep at untuk digunakan (De Lux, 2004; Nollet, 2000).

Seleksi tipe KCKT secara cepat dapat dilakukan dengan men getahui massa molekul relatif. Jika massa molekul relatif $>2000$ dapat menggunakan kromatografi eksklusi. Jika sampel larut dalam air, maka menggunakan fasa gerak air dan fasa diam Sephadex atau Bondagel Seri E. Tetapi, jika sampel larut dalam pelarut organik maka harus menggunakan fase gerak organik dan fase diam Styragel atau MicroPak TSK gel. Seleksi tipe KCKT dapat dilihat pada Gambar 2.9 (De Lux, 2004; Nollet, 2000).

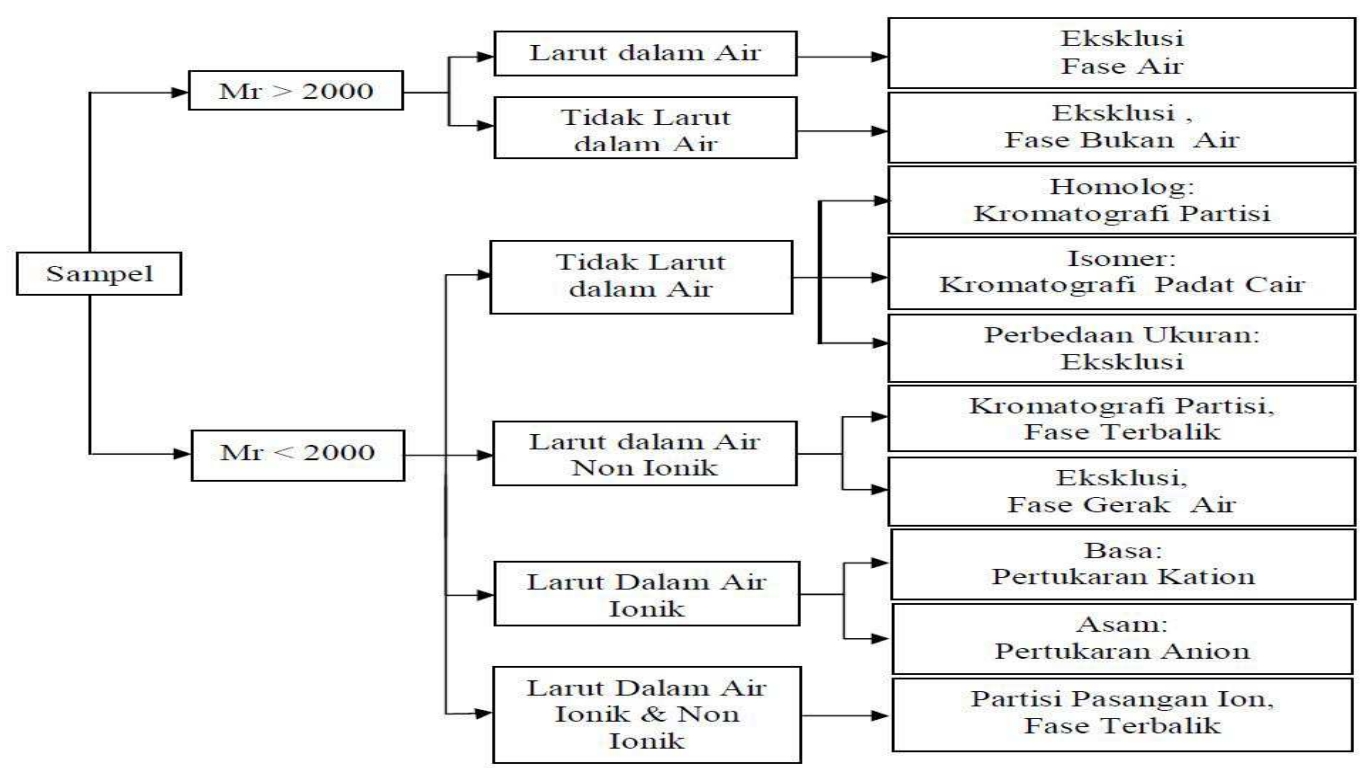

Gambar 2.9 Seleksi Tipe Kromatografi Cair Kin erja Tinggi 
Jika massa molekul relatif $<2000$ dengan mempertimbangkan kelarutan sampel dapat dilakukan sebagai berikut:

a. Sampel tidak larut dalam air, maka dianjurkan untuk menggunakan kromatografi partisi atau kromatografi padat cair. Jika analisis dilakukan rutin, disarankan menggunakan kromatografi partisi fase terikat normal karena perawatan kolom tidak rumit. Untuk sampel isomer, lebih baik digunakan kromatografi padat cair. Sampel yang memiliki perbedaan ukuran partikel digunakan kromatografi eksklusi sterik den gan fase gerak organik.

b. Sampel larut dalam air, maka digunakan kromatografi partisi fase terbalik atau kromatografi penukar ion. Kelarutan sampel dipengaruhi oleh keasaman $(\mathrm{pH})$, maka kromatografi penukar ion sebagai pilihan utama. Untuk kelarutan sampel yang tidak dipengaruhi oleh $\mathrm{pH}$ dan bersifat non ionik, maka kromatografi partisi fase terbalik sebagai pilihan terbaik.

\subsubsection{Fase Gerak Kromatografi Cair Kinerja Tinggi}

Pemilihan fase gerak hany a dapat dilakukan berdasarkan eksperimen trial and error hingga diperoleh kromatogram y ang dih arapkan. Fase gerak biasany a terdiri atas campuran pelarut y ang mempunyai day a elusi dan resolusi terhadap senyawa dalam sampel. Day a elusi dan resolusi ditentukan oleh polaritas pelarut, polaritas fase diam dan sifat komponen-komponen sampel. Untuk fase normal, yaitu fase diam lebih polar daripada fase gerak dan mempunyai kemampuan elusi meningkat dengan meningkatnya polaritas pelarut. Sementara untuk fase terbalik, fase diam kurang polar daripada fase gerak dan mempunyai kemampuan elusi menurun dengan meningkatny a polaritas pelarut (Dong, 2006; De Lux, 2004). 
Senyawa asam lemah atau basa lemah dipisahkan dengan menggunakan fase gerak buffer untuk memperbaiki resolusi dan selektivitas. Pada larutan buffer asam, senyawa basa akan terionisasi sehingga lebih cepat terelusi, sedangkan senyawa asam tidak terionisasi sehingga lebih lambat terelusi atau sebaliknya (Dong, 2006).

Larutan buffer yang dipilih sebaiknya memiliki $\mathrm{pH}$ mendekati $\mathrm{pKa}$ senyawa sampel, kapasitas buffer y ang cukup untuk menahan perubahan $\mathrm{pH}$ serta range $\mathrm{pH}$ yang sesuai untuk senyawa sampel. Biasany a lebih baik buffer dengan $\mathrm{pH} \pm 1$ unit dari $\mathrm{pKa}$ senyawa sampel, namun dapat juga digunakan buffer dengan $\mathrm{pH} \pm 1,50$ unit dari pKa seny awa sampel (Dong, 2006).

Elusi dapat dilakukan dengan cara isokratik, yaitu komposisi fase gerak tetap selama elusi atau dengan cara komposisi fase gerak berubah-ubah selama elusi yang biasa disebut dengan cara gradien. Elusi gradien digunakan untuk meningkatkan resolusi campuran yang kompleks, terutama jika sampel mempuny ai kisaran polaritas y ang luas (De Lux, 2004).

Fase gerak yang paling sering digunakan pada fase terbalik adalah campuran larutan buffer dengan metanol atau campuran air dengan asetonitril. Untuk pemisahan dengan fase normal digunakan campuran pelarut hidrokarbon dengan pelarut yang terklorisasi atau menggunakan pelarut-pelarut jenis alkohol (De Lux, 2004).

Fase gerak sebelum digunakan harus disaring untuk menghindari partikelpartikel kecil. Selain itu, adanya gas dalam fase gerak juga harus dihilangkan, sebab adanya gas akan berkumpul dengan komponen lain terutama di dalam pompa dan detektor sehingga akan mengganggu analisis (De Lux, 2004). 


\subsubsection{Fase Diam Kromatografi Cair Kinerja Tinggi}

Kebany akan fase diam pada KCKT berupa silika y ang dimodifikasi secara kimiawi, silika yang tidak dimodifikasi atau polimer stiren dan divinil benzena. Permukaan silika merupakan permukaan yang polar dan sedikit asam, karena adany a residu gugus silanol $(\mathrm{Si}-\mathrm{OH})$. Silika dapat dimodifikasi secara kimiawi dengan menggunakan reagen seperti klorosilan. Reagen akan bereaksi dengan gugus silanol dan diganti den gan gugus fungsi yang lain (De Lux, 2004).

Oktadesil silika, ODS atau C-18 merupakan fase diam y ang paling banyak digunakan, karena mampu memisahkan senyawa dengan kepolaran rendah, sedang, maupun tinggi. Oktil atau rantai alkil yang lebih pendek lebih sesuai untuk senyawa polar. Silika aminopropil dan sianopropil lebih baik sebagai pengganti silika yang tidak dimodifikasi. Silika yang tidak dimodifikasi akan memberikan waktu retensi yang bervariasi disebabkan adanya kandungan air (De Lux, 2004).

\subsection{Parameter Kromatografi Cair Kinerja Tinggi}

Optimasi kondisi KCKT dilakukan dengan parameter waktu retensi $\left(t_{\mathrm{R}}\right)$, faktor kapasitas $\left(k^{\prime}\right)$, jumlah plat teoritis $(N)$, resolusi $\left(R_{s}\right)$, selektivitas $(\alpha)$ dan faktor tailing $(\mathrm{Ft})$.

\subsubsection{Waktu retensi}

Waktu y ang dibutuhkan seny awa bergerak melalui kolom menuju detektor disebut waktu retensi. Waktu retensi diukur berdasarkan waktu dimana sampel diinjeksikan sampai sampel menunjukkan ketinggian puncak maksimum dari 
seny awa. Waktu retensi senyawa dapat diilustrasikan seperti Gambar 2.10 (Dong, 2006; Ornaf dan Dong, 2005; Sny der, et al., 1997; Snyder dan Kirkland, 1979).

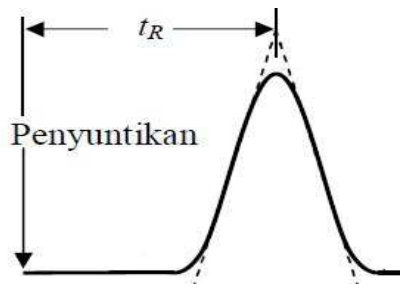

Gambar 2.10 Waktu Retensi Seny awa

\subsubsection{Faktor Kapasitas}

Faktor kapasitas adalah ukuran kemampuan kolom mempertahankan komponen sampel. Faktor kapasitas merupakan waktu zat terlarut berada dalam fase diam relatif terhadap waktu dalam fase gerak. Nilai faktor kapasitas dapat dihitung dengan persamaan 2.1 (Snyder, et al., 2010; Dong, 2006).

$$
k^{\prime}=\frac{t_{R}^{\prime}}{t_{0}}=\frac{t_{R}-t_{0}}{t_{0}}
$$

Di mana: $\mathrm{k}^{\prime}=$ faktor kapasitas

$$
\begin{aligned}
& \mathrm{t}_{\mathrm{R}}=\text { waktu tambat suatu senyawa } \\
& \mathrm{t}_{0}=\text { waktu tambat hampa }
\end{aligned}
$$

Volume void adalah total volume fase gerak yang terkandung dalam kolom. Volume void merupakan volume kolom kosong dikurangi volume fase diam. Sebagian besar kolom, volume void dapat diperkirakan $65 \%$ dari volume kolom kosong (Dong, 2006).

Rasio konsentrasi seny awa dalam fase diam dengan fase gerak dinyatakan dengan koefisien partisi $(\mathrm{K})$. Sedangkan rasio mol senyawa dalam fase diam dengan fase gerak dinyatakan sebagai faktor kapasitas, maka faktor kapasitas 
berbanding lurus dengan koefisien partisi dan volume fase diam serta berbanding terbalik den gan volume fase gerak atau volume void (Dong, 2006).

Pemisahan dengan nilai $\mathrm{k} \leq 10$ untuk semua puncak berhubungan dengan $\mathrm{t}_{\mathrm{o}} \mathrm{y}$ ang sempit, meningkatkan deteksi puncak dan jangka waktu yang pendek sehingga lebih banyak sampel dapat dianalisis setiap hari. Nilai $\mathrm{k}<1$ dapat meny ebabkan resolusi kurang baik, kemungkinan terjadi tumpang tindih senyawa dengan matriks y ang biasanya menumpuk di dekat $\mathrm{t}_{\mathrm{o}}$. Oleh karena itu, parameter faktor kapasitas sebaikny a berada pada rentang 1 sampai 10 untuk semua puncak. Namun, ada kemungkinan untuk memperluas rentang y ang juga disukai, y aitu 0,5 $\leq \mathrm{k} \leq 20$ (Snyder, et al., 1997; Dong, 2006; Snyder, et al., 2010).

\subsubsection{Jumlah Plat Teoritis}

Jumlah plat teoritis (N) merefleksikan jumlah waktu senyawa berpartisi antara dua fase selama melalui kolom dan menggambarkan efisiensi kolom. Jumlah plat teoritis suatu kromatografi dapat dihitung dengan persamaan 2.2 (Ornaf dan Dong, 2005; Sny der, et al., 1997; Sny der dan Kirkland, 1979).

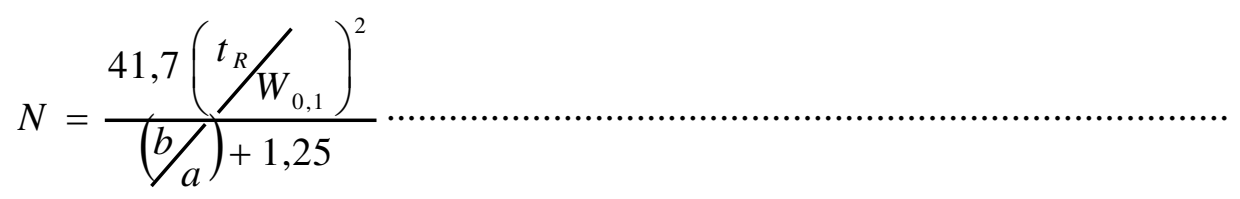

Di mana: $\mathrm{N} \quad=$ Jumlah plat teoritis

$$
\begin{aligned}
& \mathrm{t}_{\mathrm{R}} \quad=\text { Waktu retensi seny awa } \\
& \mathrm{W}_{0,1}=\text { Lebar dasar puncak pada posisi } 10 \% \text { dari dasar tinggi puncak } \\
& a=b=\text { Lebar salah satu sisi kromatogram }
\end{aligned}
$$




\subsubsection{Resolusi}

Resolusi atau daya pemisahan dua pita yang berdekatan didefinisikan sebagai jarak antara dua puncak pita dibagi dengan luas rata-rata pita. Nilai resolusi $>1,5$ menunjukkan bahwa kedua puncak terpisah secara sempurna. Untuk pengembangan metode, sebaiknya dilakukan sampai resolusi $\geq 2$ (Snyder, et al., 2010). Resolusi dua senyawa dapat diilustrasikan seperti Gambar 2.11 dan dapat dihitung dengan persamaan 2.3 (Dong, 2006; Ornaf dan Dong, 2005; Snyder, et al., 1997; Sny der dan Kirkland, 1979).

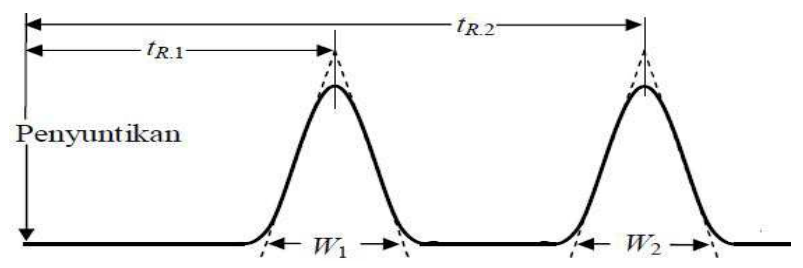

Gambar 2.11 Resolusi Dua Senyawa

$R_{s}=\frac{2\left(t_{R .2}-t_{R .1}\right)}{\left(W_{2}+W_{1}\right)}$

Di mana: Rs = Resolusi dari dua pita

$\mathrm{t}_{\mathrm{R} .1}=$ Waktu retensi seny awa pertama

$\mathrm{t}_{\mathrm{R} .1}=$ Waktu retensi seny awa kedua

$\mathrm{W}_{1}=$ Luas area pita pertama

$\mathrm{W}_{2}=$ Luas area pita kedua

\subsubsection{Selektivitas}

Selektivitas merupakan kemampuan sistem KCKT untuk memisahkan senyawa yang berbeda. Nilai selektivitas ditentukan sebagai rasio perbandingan faktor kapasitas dari senyawa yang berbeda. Nilai selektivitas harus $>1$ agar terjadi pemisahan sempurna. Selektivitas bergantung pada sifat senyawa dan 
interaksi antara senyawa den gan permukaan fase diam dan fase gerak. Selektivitas dihitung mempergunakan persamaan 2.4 (Dong, 2006)

$\alpha=\frac{k_{2}}{k_{1}}$

Di mana: $\alpha=$ selektivitas

$\mathrm{k}_{1}=$ faktor kapasitas seny awa pertama

$\mathrm{k}_{2}=$ faktor kapasitas seny awa kedua

\subsubsection{Faktor Tailing}

Jika puncak yang akan dikuantifikasi adalah asimetri (tidak setangkup), maka perhitungan asimetrisitas merupakan cara yang baik untuk mengontrol sistem kromatografi. Peningkatan puncak asimetri akan menyebabkan penurunan resolusi, batas deteksi, dan presisi. Pengukuran derajat asimetris puncak dapat dihitung dengan faktor tailing dan faktor asimetris. Faktor tailing dihitung dengan menggunakan lebar puncak pada ketinggian 5\% dengan persamaan 2.5. Gambar 2.12 menunjukkan cara menghitung nilai faktor tailing (Dong, 2006; Ornaf dan Dong, 2005; Snyder, et al., 1997; Sny der dan Kirland, 1979).

$$
F t=\frac{a+b}{2 a}
$$

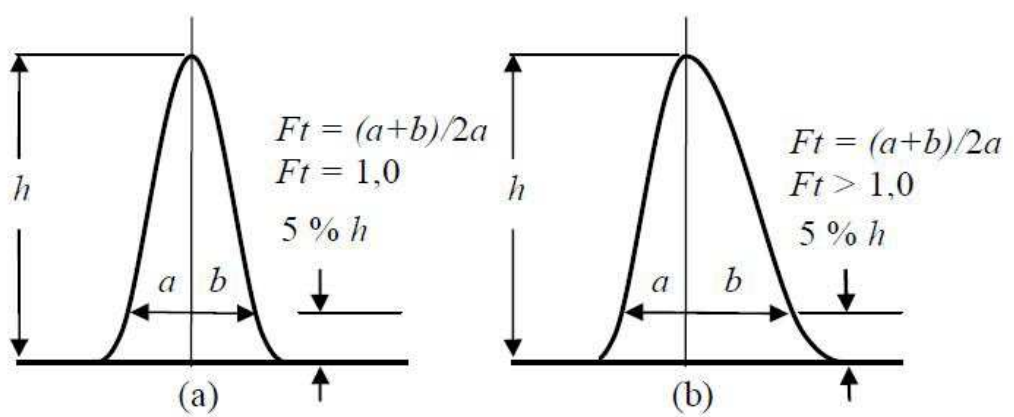

Gambar 2.12 Pengukuran Faktor Tailing; (a) Puncak simetris dan (b) Puncak Asimetris 
Bentuk kromatogran normal jika nilai faktor tailing berada pada rentang y ang dizinkan, yaitu $0,9 \leq \mathrm{Ft} \leq 1,2$. Persyaratan umum untuk pemisahan rutin adalah $\mathrm{Ft}<2$ untuk semua puncak. Puncak utama tailing $(\mathrm{Ft}>2)$ sangat merugikan baik pemisahan dan analisis kuantitatif (Snyder, et al., 2010). Penyebab dan solusi masalah bentuk kromatogram dapat dilihat pada Tabel 2.2 (Sny der, et al., 2010; Phomenex, 2005).

Tabel 2.2 Penyebab dan Solusi Masalah Bentuk Kromatogram

\begin{tabular}{|c|c|c|c|}
\hline No & Bentuk & Penyebab & Solusi \\
\hline \multirow{5}{*}{1} & \multirow{5}{*}{$\begin{array}{l}\text { Tailing } \\
(\mathrm{Ft} \geq 1,2)\end{array}$} & Block frit & Mengganti frit \\
\hline & & Column void & Mengatur volume void \\
\hline & & Interfering peak & $\begin{array}{l}\text { - Mengunakan kolom lebih panjang, } \\
\text { - Mengubah fase gerak atau } \\
\text { - Menggunakan kolom yang lebih } \\
\text { selektif }\end{array}$ \\
\hline & & $\mathrm{pH}$ fase gerak & Mengatur $\mathrm{pH}$ fase gerak \\
\hline & & Sampel reaktif & Mengganti kolom \\
\hline \multirow{3}{*}{2} & \multirow{3}{*}{$\begin{array}{l}\text { Fronting } \\
(\mathrm{Ft}<0,9)\end{array}$} & Pelarut sampel & $\begin{array}{l}\text { Menggunakan pelarut sama dengan } \\
\text { fase gerak }\end{array}$ \\
\hline & & Sampel overload & Menurunkan konsentrasi sampel \\
\hline & & Bad column & $\begin{array}{l}\text { - Membalikkan kolom, } \\
\text { - Mengganti frit atau } \\
\text { - Mengganti kolom }\end{array}$ \\
\hline \multirow{8}{*}{3} & \multirow{8}{*}{$\begin{array}{l}\text { Broading } \\
(\mathrm{N}>75 \%)\end{array}$} & $\begin{array}{l}\text { Perubahan } \\
\text { komposisi fase } \\
\text { gerak }\end{array}$ & Membuat fase gerak y ang baru \\
\hline & & Penurunan laju alir & Mengatur laju alir \\
\hline & & $\begin{array}{l}\text { Ada kebocoran } \\
\text { antar kolom dengan } \\
\text { detektor }\end{array}$ & Mengecek dan men gatur sistem \\
\hline & & $\begin{array}{l}\text { Penurunan } \\
\text { konsentrasi buffer }\end{array}$ & Mengatur konsentrasi buffer \\
\hline & & Kontaminasi frit & Mengganti frit \\
\hline & & Kontaminasi kolom & Mengganti kolom \\
\hline & & $\begin{array}{l}\text { Penurunan volume } \\
\text { void }\end{array}$ & $\begin{array}{l}\text { - Menggatur volume void atau } \\
\text { - Mengganti kolom }\end{array}$ \\
\hline & & $\begin{array}{l}\text { Penurunan suhu } \\
\text { kolom }\end{array}$ & Mengatur suhu kolom \\
\hline
\end{tabular}




\subsection{Validasi Metode Analisis}

Metode analisis yang baru, pengembangan, jika terjadi perubahan kondisi antara kondisi analisis dan kondisi saat validasi metode sebelumny a atau terjadi perubahan dari metode standar maka harus dilakukan validasi metode. Manfaat validasi metode, antara lain: untuk mengevaluasi hasil metode analisis, menjamin prosedur analisis, menjamin keakuratan dan ulan gan hasil prosedur analis is serta mengurangi resiko penyimpangan. Validasi metode meliputi linearitas, akurasi (accuracy), batas deteksi (limit of detection), batas kuantitasi (limit of quantitation), ketelitian (precision), selektivitas (specifity) (Ravichandran, et al., 2010; Chan, et al., 2004; Harmita, 2004).

\subsubsection{Linearitas}

Koefisien korelasi merupakan indikator linearitas yang menggambarkan proporsionalitas respon luas area terhadap konsentrasi yang diukur. Hasil plot antara konsentrasi larutan baku dengan luas puncak dari masing-masing komponen digunakan untuk menentukan persamaan 2.6 yang merupakan persamaan regresi linear, dimana $a$ dan $b$ dihitung dengan persamaan 2.7 dan 2.8 . Suatu metode analisis yang valid mempunyai harga koefisien korelasi lebih dari 0,999 (Ravichandran, et al., 2010; Harmita, 2004).

$$
\begin{aligned}
& Y=a+b X
\end{aligned}
$$

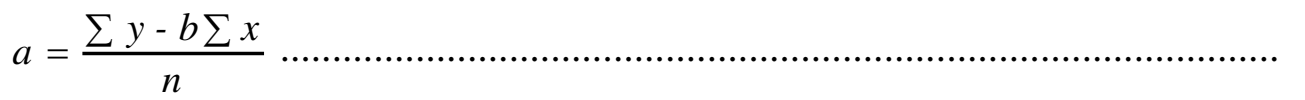

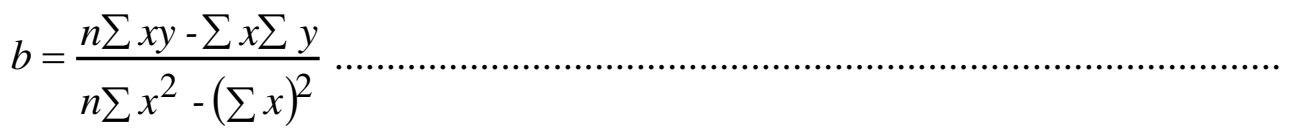


Untuk menguji linearitas hubungan konsentrasi (X) dengan luas area (Y), digunakan koefisien korelasi $(r)$ y ang dihitung dengan persamaan 2.9.

$$
r=\frac{n\left(\sum X Y\right)-\left(\sum X\right)\left(\sum Y\right)}{\sqrt{\left\{n\left(\sum X^{2}\right)-\left(\sum X\right)^{2}\right\}\left\{n\left(\sum Y^{2}\right)-\left(\sum Y\right)^{2}\right\}}}
$$

\subsubsection{Batas Deteksi dan Batas Kuantitasi}

Limit of Detection ( $L O D)$ merupakan batas konsentrasi terendah senyawa dalam sampel yang dapat dideteksi dan memberikan respon y ang signifikan oleh alat. Sedangkan Limit of Quantitation ( $L O Q$ ) adalah kuantitas terkecil senyawa dalam sampel yang masih memenuhi kriteria cermat dan seksama. Nilai $L O D$ dan $L Q D$ dihitung secara statistik melalui persamaan regresi y ang diperoleh dari kurva kalibrasi. Kemudian dihitung standar deviasi, $S D$ dengan persamaan 2.10. $L O D$ dan $L Q D$ dihitung dengan persamaan 2.11 dan 2.12 (Ravichandran, et al., 2010; Chan, et al., 2004; Harmita, 2004; Huber, 1999).

$$
\begin{aligned}
& S D=\sqrt{\frac{\sum(Y-Y i)}{n-2}} \\
& L O D=\frac{3 S D}{b} \ldots \ldots \\
& L O Q=\frac{10 S D}{b} \ldots .
\end{aligned}
$$

Di mana: SD = Standar deviasi

$\mathrm{Y}=$ Luas area terdeteksi setiap konsentrasi

Yi $=$ Luas area teoritis setiap konsentrasi

$\mathrm{n}=$ Jumlah ulangan peny untikan sampel

$b=$ Slope persamaan regresi dari kurva kalibrasi

Yi dihitung dari persamaan regresi linear, yaitu dengan mensubstitusikan konsentrasi (X) pada persamaan 2.6. 


\subsubsection{Akurasi}

Akurasi adalah kemampuan suatu alat ukur untuk memberikan respon yang dekat dengan nilai sebenarnya. Akurasi dapat ditentukan melalui dua cara, yaitu metode simulasi (spiked-placebo recovery) atau metode penambahan bahan baku (standard addition method). Dalam metode penambahan bahan baku, sampel dianalisis lalu sejumlah tertentu senyawa y ang diperiksa (biasany a $80 \%$ - 120\%) ditambahkan ke dalam sampel dan dianalisis kembali. Selisih kedua hasil dibandingkan dengan kadar yang sebenarnya (hasil yang diharapkan). Akurasi dinyatakan sebagai persentase perolehan kembali (recovery) yang ditambahkan dan dapat ditentukan dengan persamaan 2.13. Rentang persentase recovery dapat dilihat pada Tabel 2.3 (Ravichandran, et al., 2010; Chan, et al., 2004; Harmita, 2004; Huber, 1999).

Tabel 2.3 Rentang Persentase Recovery

\begin{tabular}{|c|c|c|}
\hline No & Kadar Seny awa dalam Sampel (\%) & Recovery $(\%)$ \\
\hline 1 & $>10$ & $95-102$ \\
\hline 2 & $>1$ & $92-105$ \\
\hline 3 & $>0,1$ & $90-108$ \\
\hline 4 & $>0,01$ & $85-110$ \\
\hline 5 & $>0,001$ & $80-115$ \\
\hline
\end{tabular}

Sumber: Farrar dan Whaite, 2012.

Persentase Recovery $=\frac{C_{1}-C_{2}}{C_{3}} \times 100 \%$

Di mana:

$\mathrm{C}_{1}=$ Konsentrasi seny awa dalam sampel dan baku

$\mathrm{C}_{2}=$ Konsentrasi seny awa dalam sampel

$\mathrm{C}_{3}=$ Konsentrasi seny awa baku y ang sebenarny a ditambahkan ke dalam sampel 


\subsubsection{Presisi}

Uji presisi atau uji keseksamaan digunakan untuk mengevaluasi tingkat kedekatan antara hasil analisis sehingga diketahui kesalahan acak analisis. Uji presisi dapat berupa uji keterulangan (ripitabilitas) dan uji ketertiruan (reproduksibilitas).

Uji ripitabilitas merupakan uji keseksamaan metode jika dilakukan berulang kali oleh analis pada kondisi yang sama dalam interval waktu yang singkat. Ripitabilitas dilakukan dengan menggunakan sampel yang identik dari batch yang sama, sehingga dapat memberikan ukuran keseksamaan pada kondisi yang normal. Sedangkan reproduksibilitas adalah keseksamaan metode yang dikerjakan pada kondisi, tempat, peralatan, pereaksi, pelarut atau analis yang berbeda dengan sampel diduga identik serta dari batch yang sama. Reproduksibilitas dapat juga dilakukan dalam laboratorium yang sama dengan menggunakan peralatan, pereaksi, pelarut atau analis y ang berbeda.

Uji presisi dilakukan paling sedikit enam kali ulangan yang diambil dari campuran sampel dengan matriks yang homogen. Kriteria seksama diberikan jika metode memberikan persentase relative standard deviation yang diizinkan. Persentase relative standard deviation uji ripitabilitas dan uji reproduksibilitas masing- masing dapat dilihat pada Tabel 2.4 dan Tabel 2.5. Standar deviasi dapat dihitung dengan persamaan 2.14 dan relative standard deviation dihitung dengan persamaan 2.15 (Ravichandran, et al., 2010; Chan, et al., 2004; Harmita, 2004; Burn, et al., 2002; Huber, 1999).

$$
S D=\sqrt{\frac{\sum(X-\bar{X})^{2}}{n-1}}
$$


Persentase RSD $=\frac{S D}{\bar{X}} \times 100 \%$

Di mana: $\mathrm{SD}=$ Standar deviasi

$\mathrm{RSD}=$ Relative standard deviation

$\bar{X}=$ Kadar rata-rata y ang diperoleh dari percobaan

Tabel 2.4 Persentase Relative Standard Deviation Uji Ripitabilitas

\begin{tabular}{|c|c|c|}
\hline No & Kadar Senyawa dalam Sampel (\%) & Relative Standard Deviation (\%) \\
\hline 1 & $>10$ & 1,5 \\
\hline 2 & $>1$ & 2 \\
\hline 3 & $>0,1$ & 3 \\
\hline 4 & $>0,01$ & 4 \\
\hline 5 & $>0,001$ & 6 \\
\hline
\end{tabular}

Sumber: Farrar dan Whaite, 2012.

Tabel 2.5 Persentase Relative Standard Deviation Uji Reproduksibilitas

\begin{tabular}{|c|c|c|}
\hline No & Kadar Senyawa dalam Sampel (\%) & Relative Standard Deviation $(\%)$ \\
\hline 1 & $>10$ & 3 \\
\hline 2 & $>1$ & 4 \\
\hline 3 & $>0,1$ & 6 \\
\hline 4 & $>0,01$ & 8 \\
\hline 5 & $>0,001$ & 11 \\
\hline
\end{tabular}

Sumber: Farrar dan Whaite, 2012.

\subsubsection{Selektivitas}

Selektivitas dilakukan dengan membandingkan waktu retensi larutan baku, larutan sampel dan campuran larutan sampel dengan baku. Hasil penelitian harus menunjukkan pada larutan baku dan sampel dan campuran larutan sampel dengan baku muncul peak area pada waktu retensi $\left(t_{R}\right)$ relatif sama, sehingga metode dapat diny atakan selektif (Ravichandran, et al., 2010; Chan, et al., 2004; Harmita, 2004; Huber, 1999). 


\subsection{Metode Penetapan Kadar Pemanis, Pengawet dan Pewarna}

Penetapan kadar pemanis, pengawet dan pewarna yang terdapat dalam sirup esens dapat ditentukan dengan KCKT. Analisis menggunakan metode KCKT memiliki beberapa kelebihan, seperti: waktu analisis cepat, resolusi dan sensitivitas tinggi serta dapat dihubungkan dengan bermacam-macam detektor y ang sesuai (De Lux, 2004).

Ree dan Stoa (2011), telah melakukan penetapan kadar sakarin, aspartam, asam benzoat dan kaffein dalam minuman ringan menggunakan KCKT, kolom Phenomenex Kinetex C-18, detektor UV dengan panjang gelombang $220 \mathrm{~nm}$ dan fase gerak campuran metanol dengan buffer fosfat pH 3 (20:80), suhu kolom $35^{\circ} \mathrm{C}$, dan laju alir $1 \mathrm{ml} / \mathrm{menit}$. Begitu juga Serdar dan Knezevic (2011), telah berhasil melakukan pemisahan aspartam, natrium sakarin, kalium asesulfam dan siklamat dengan KCKT; detektor diode array pada panjang gelombang masingmasing $193 \mathrm{~nm}, 202 \mathrm{~nm}, 226 \mathrm{~nm}$ dan $314 \mathrm{~nm}$; kolom C-18, fase gerak campuran asetonitril dengan buffer fosfat $\mathrm{pH} 3,5$ (15:75); laju alir 1,5 ml/menit dan volume injeksi $10 \mu$ l. Sementara Hay un, dkk. (2004), sudah melakukan penetapan kadar campuran sakarin, aspartam, asam benzoat, kafein dan asam sorbat dengan menggunakan KCKT-UV pada panjang gelombang $254 \mathrm{~nm}$, fase gerak campuran asetonitril dengan buffer fosfat pH 5 (5:95), dan laju alir $1 \mathrm{ml} / \mathrm{menit}$. Penetapan kadar siklamat sebagai zat tunggal dalam minuman ringan juga telah dilakukan dengan menggunakan KCKT, detekor UV pada panjang gelombang $200 \mathrm{~nm}$, fase gerak campuran kalium dihidrogen fosfat $0,0125 \mathrm{mg} / \mathrm{L}$ den gan metanol (7:3) dan laju alir $1 \mathrm{ml} / \mathrm{menit}$ (Novelina, dkk., 2009). 
Penetapan kadar natrium benzoat dan kalium sorbat dalam jus buah, soda, kecap, saus tomat, selai kacang dan keju telah dilakukan dengan menggunakan KCKT- UV diode array $225 \mathrm{~nm}$, kolom C-18, fase terbalik, fase gerak campuran asetonitril dengan buffer asetat $\mathrm{pH} 4,2(1: 5)$, suhu kolom $20^{\circ} \mathrm{C}$ dan laju alir 0,8 ml/menit (Pylypiw dan Grether, 2000). Khosrokhavar, et al. (2010), juga telah melakukan penetapan kadar zat, laju alir dan suhu kolom yang sama dalam minuman ringan dan ekstrak herbal dengan detektor UV-Vis pada panjang gelombang $254 \mathrm{~nm}$, fase gerak campuran asetonitril dan buffer asetat $\mathrm{pH} 4,4$ (40: $60)$.

Veni, et al. (2011), telah melakukan penetapan kadar campuran tartrazin dan sunset yellow secara simultan menggunakan KCKT pada panjang gelombang $244 \mathrm{~nm}$. Ramakrishnan, et al. (2011), telah melakukan penetapan kadar tartrazin menggunakan KCKT, kolom Phenomenex C-18, fase gerak campuran buffer amonium asetat pH 8 dengan asetonitril dan metanol (2:1:1), detektor diode array $426 \mathrm{~nm}$ dan laju alir 1ml/menit. Diacu dan Ene (2009), telah berhasil melakukan penetapan kadar tartrazin dan sunset yellow dalam minuman ringan dengan menggunakan KCKT, detektor dioda array 470 nm, kolom Hypersil C-8, fase gerak campuran A (buffer fosfat pH 6,5) dengan B (campuran asetonitril-metanol, 1 : 4), elusi gradien, suhu kolom $30^{\circ} \mathrm{C}$, laju al ir $1,0 \mathrm{ml} / \mathrm{menit}$ dan volume injeksi $10 \mu 1$. Demikian juga Jurcovan, et al. (2012), telah menetapkan kadar tartrazin dan sunset yellow dengan menggunakan KCKT pada panjang gelombang tunggal 470 nm. Daftar beberapa penelitian optimasi metode, validasi metode atau penetapan kadar pemanis, pengawet dan pewarna dengan metode Kromatografi Cair Kinerja Tinggi dapat dilihat pada Tabel 2.6. 
Tabel. 2.6 Daftar Beberapa Penelitian Optimasi dan Validasi metode atau Penetapan Kadar Pemanis, Pengawet dan Pewarna dengan Metode Kromatografi Cair Kinerja Tinggi

\begin{tabular}{|c|c|c|c|c|c|c|c|c|}
\hline \multirow{2}{*}{ Sanpel } & \multirow{2}{*}{ Metode } & \multicolumn{6}{|c|}{ Kadar Senyawa dalam Sampel (ppm) } & \multirow{2}{*}{ Peneliti (Tahun) } \\
\hline & & Sakarin & Silkamat & Benzoat & Sorbat & Tartrazin & Sunset Yellow & \\
\hline - Minuman ringan & $\begin{array}{l}\text { - KCKT UV } 200 \mathrm{~nm} \text { (Validasi Metode) } \\
\text { - Kolom Nucleosil C18 (12 cm x 4.6 mm) } \\
\text { - Fase Gera } \mathrm{KH}_{2} \mathrm{PO}_{4} 0,0125 \mathrm{mg} / \mathrm{L}: \text { Metanol }(7: 3) \\
\text { - Laju Alir } 1 \mathrm{ml} / \text { menit }\end{array}$ & - & $\mathrm{v}$ & - & - & - & - & Novelina, dikk (2009) \\
\hline - Minuman ringan & $\begin{array}{l}\text { - KCKT DAD } 202 \mathrm{~nm}, 314 \mathrm{~nm} \\
\text { - Kolom C18 (15 cm x } 4.6 \mathrm{~mm}, 5 \mu \mathrm{m}) \\
\text { - Fase Geralk Buffer Fosfat pH } 3,5: \text { Asetonitril (85: } 15) \\
\text { - Laju Alir } 1,5 \mathrm{ml} / \text { menit. } \\
\end{array}$ & $35-77$ & $80-622$ & - & - & - & - & Serdar dan Knezevic (2011) \\
\hline $\begin{array}{l}\text { - Jus buah } \\
\text { : Soda } \\
\text { - Kecap } \\
\text { - Saus tomat } \\
\text { - Selai kacang }\end{array}$ & $\begin{array}{l}\text { - KCKT DAD } 225 \text { dan } 255 \mathrm{~nm} \\
\text { - Kolom Supeloosil LC-18 }(25 \mathrm{~cm} 34.6 \mathrm{~mm}, 5 \mu \mathrm{m}) \\
\text { - Suhu } 200 \mathrm{C} \\
\text { - Fase Gerak Buffer Asetat pH } 4,2: \text { Asetonitril }(5: 1) \\
\text { - Laju Alir } 0.8 \mathrm{ml} / \text { menit }\end{array}$ & - & - & $12-60$ & $350-450$ & - & - & Pylypiw dan Grether (2000) \\
\hline - Sirup & $\begin{array}{l}\text { - KCKT UV } 228 \text { nm (Optimasi pH) } \\
\text { - Kolom C18 RP } \\
\text { - Fase Gerak Metanol : Air }(1: 3)) \\
\text { - Laju Alir } 1,2 \text { ml/menit } \\
\end{array}$ & - & - & 0 & - & - & - & Hartono (2007). \\
\hline $\begin{array}{l}\text { - Minuman ringan } \\
\text { - Elstrak herbal }\end{array}$ & $\begin{array}{l}\text { - KCKT DAD } 254 \mathrm{~nm} \\
\text { - Kolom C-18 (250×4.6mm) } \\
\text { - Fase Gerak Buffer Asetat pH 4,4: Asetonitril }(60: 40) \\
\text { - Laju Alir 0,8 ml/menit } \\
\end{array}$ & - & - & $4-2313$ & $1-316$ & - & - & Khosrokhavar, et al (2010) \\
\hline - Sirup & $\begin{array}{l}\text { - KCKT UV } 230 \mathrm{~nm} \\
\text { - Kolom Shimpac VP-ODS (4,6 mm x } 250 \mathrm{~mm}) \text { RP } \\
\text { - Fase Gerak Metanol : Buffer Fosfat }(30: 70) \\
\text { - Laju Alir } 0,8 \mathrm{ml} / \mathrm{menit}\end{array}$ & - & - & $237-626$ & $31-545$ & - & - & Sibarani $(2010)^{x}$ \\
\hline
\end{tabular}

Keterangan:

$0=$ Optimasi metode

$\mathrm{x}=$ Kadar sakarin, natrium benzoat dan kalium sorbat dalam $\mathrm{mg} / \mathrm{kg}$ sampel

$\mathrm{v}=$ Validasi metode

- = Tidak dilakukan penelitian 
Tabel. 2.6 Daftar Beberapa Penelitian Optimasi dan Validasi metode atau Penetapan Kadar Pemanis, Pengawet dan Pewarna dengan Metode Kromatografi Cair Kinerja Tinggi (Lanjutan)

\begin{tabular}{|c|c|c|c|c|c|c|c|c|}
\hline \multirow{2}{*}{ Sampel } & \multirow{2}{*}{ Metode } & \multicolumn{6}{|c|}{ Kadar Senyawa dalam Sampel (ppm) } & \multirow{2}{*}{ Peneliti (Tahun) } \\
\hline & & Sakarin & Siklamat & Benzoat & Sorbat & Tartrazin & Sunset Yellow & \\
\hline $\begin{array}{l}\text { - Minuman ringan } \\
\text { berkarbonasi }\end{array}$ & $\begin{array}{l}\text { - KCKT PDA } 254 \mathrm{~nm} \\
\text { Kolom Latek C } 18(15 \mathrm{~cm} \times 4.0 \mathrm{~mm}) \\
\text { - Fase Geral Buffer Fosfat pH } 5: \text { Asetonitril }(95: 5) \\
\text { - Laju Alir } 1 \mathrm{ml} / \text { menit. }\end{array}$ & 1112 & - & $10-206$ & - & - & - & Hayun, dikk (2004) \\
\hline - Sirup & $\begin{array}{l}\text { - KCKT UV } 225 \mathrm{~nm} \\
\text { - Kolom ODS } \\
\text { - Fase Gerak Buffer Fosfat : Metanol }(92: 8) \\
\text { - Laju Alir } 1 \mathrm{ml} / \text { menit }\end{array}$ & 564 & - & 1068 & - & - & - & Subani $(2008)^{x}$ \\
\hline - Minuman ringan & $\begin{array}{l}\text { - KCKT UV-Vis } 220 \mathrm{~nm} \\
\text { - Kolom Phenomenex Kinetex XB-C18 ( } 50 \text { x } 4.6 \mathrm{~mm}, 2.6 \mu \mathrm{m}) \\
\text { - Suhu } 35^{\circ} \mathrm{C} \text {. Fase Gerak Buffer Asetat pH } 3 \text { : Metanol }(80: 20) \\
\text { - Laju Alir } 1 \mathrm{ml} / \text { menit }\end{array}$ & $99-162$ & - & $123-150$ & - & - & - & Ree dan Stoa (2011) \\
\hline - Minuman ringan & $\begin{array}{l}\text { - KCKT DAD } 470 \mathrm{~nm} \\
\text { - Kolom Hypersil C-8 }(250 \mathrm{~cm} \times 4.6 \mathrm{~mm}, 5 \mu \mathrm{m}) \\
\text { Suhu } 30^{\circ} \mathrm{C} \\
\text { - Fase Gerak Buffer Fosfat pH } 6,5 \text { dan Campuran Asetonitril-Metanol }(1: 4) \\
\text { - Laju Alir } 1 \mathrm{~m} 1 / \text { menit } \\
\text { - Elusi Gradien }\end{array}$ & - & - & - & - & $2-17$ & $1-13$ & Diacu dan Ene (2009) \\
\hline - Makanan & $\begin{array}{l}\text { - KCKT } 244 \mathrm{~nm} \\
\text { - Kolom Phenomenex C-18 (250 cm x } 4.6 \mathrm{~mm}, 5 \mu \mathrm{m}) \\
\text { - Fase Gerak Buffer Fosfat pH } 7,5: \text { Asetonitril }(80: 20) \\
\text { - Laju Alir } 0,7 \mathrm{ml} / \text { menit }\end{array}$ & - & - & - & - & 97 & 1057 & Veni, et al (2011) \\
\hline - Minuman ringan & $\begin{array}{l}\text { - KCKT DAD } 470 \mathrm{~nm} \\
\text { - Kolom Hypersil C-8 }(250 \text { x } 4.6 \mathrm{~mm}, 5 \mathrm{~mm}) \\
\text { - Suhu } 30^{\circ} \mathrm{C} \\
\text { Fase Gerak Buffer Fosfat pH } 8 \text { dan Campuran Asetonitril-Metanol }(1: 4) \\
\text { - Laju Alir } 1 \mathrm{ml} \text { /menit } \\
\text { - Elusi Gradien }\end{array}$ & - & - & - & - & 13 & 2 & Jurcovan, et al (2012) \\
\hline
\end{tabular}

Keterangan

$0=$ Optimasi metode

$\mathrm{x}=$ Kadar sakarin, natrium benzoat dan kalium sorbat dalam $\mathrm{mg} / \mathrm{kg}$ sampel

$\mathrm{v}=$ Validasi metode

- = Tidak dilakukan penelitian 


\subsection{Perhitungan Kadar Pemanis, Pengawet dan Pewarna}

Luas area komponen-komponen y ang dianalisis diplot ke dalam persamaan regresi linear untuk uji kuantitatif, sehingga diperoleh kadar masing-masing senyawa (c). Kemudian ditentukan kadar senyawa dalam sampel dengan persamaan 2.16 dan persamaan 2.17 (Wrolstad, et al., 2005).

$$
\begin{aligned}
& M=\frac{c}{W} \times \frac{F p}{1000} \times k \\
& P=\frac{M}{10^{6}} \times 100 \% \\
& \text { Di mana: } \mathrm{M} \text { = Kadar rata-rata BTM }(\mathrm{mg} / \mathrm{kg}) \\
& \mathrm{c}=\text { Kadar rata-rata BTM dari peny untikan }(\mu \mathrm{g} / \mathrm{ml}) \\
& \mathrm{W}=\text { Massa rata-rata penimbangan sampel }(\mathrm{kg}) \\
& \mathrm{Fp}=\text { Faktor Pengenceran } \\
& \mathrm{k}=\text { Angka kemurnian bahan baku (\%) } \\
& \mathrm{P}=\text { Kadar rata-rata BTM }(\%)
\end{aligned}
$$




\section{BAB III}

\section{METODE PENELITIAN}

\subsection{Metode Penelitian}

Metode yang digunakan pada penelitian adalah metode eksperimental dan deskriptif. Metode eksperimental dengan maksud mengetahui pengaruh atau hubungan antara variabel bebas (X) yang disebut faktor perlakuan dengan variabel terikat (Y) yang disebut faktor pengamatan (Arikunto, 2002). Dalam penelitian eksperimental, sebagai variabel bebas adalah volume void, panjang gelombang, $\mathrm{pH}$ fase gerak, komposisi fase gerak, laju alir dan suhu kolom sedangkan variabel terikat adalah faktor kapasitas, waktu retensi, faktor tailing, resolusi dan jumlah plat teoritis.

Metode penelitian deskriptif I dilakukan dengan menganalisis parameter validasi yang meliputi: linearitas, batas deteksi, batas kuantitasi, akurasi, presisi dan selektivitas dengan indikator yang meliputi koefisien korelasi, konsentrasi minimum terdeteksi, konsentrasi minimum terkuantitasi, persen recovery dan persen relative standard deviation dan waktu retensi.

Metode penelitian deskriptif II dilakukan untuk merekam kadar natrium sakarin, natrium siklamat, natrium benzoat, kalium sorbat, tartrazin, sunset yellow dalam beberapa sirup esens y ang beredar di kota Medan.

\subsection{Tempat dan Waktu Penelitian}

Penelitian dilakukan di Laboratorium Penelitian Fakultas Farmasi USU Medan dari bulan Agustus 2012 sampai dengan Juli 2013. 


\subsection{Alat dan Bahan Penelitian}

\subsubsection{Alat Penelitian}

Alat-alat yang digunakan, antara lain: seperangkat alat KCKT (Agilent 1290 Infinity Diode Array Detector), kolom Zorbax Eclipse Plus C-18 100 x 4,6 x 3,5 $\mu \mathrm{m}$ (Agilent), seperangkat alat spektrofotometer UV-Vis (UV Probe 1800 Shimadzu), pH meter digital tipe pen (ATC), sonikator (Bransonic), timbangan analitik (Boeco), pompa vacum (Boeco), pompa vacum (Bust), peny aring sellu losa nitrat $0,45 \mu \mathrm{m}$; penyaring politetrafluoroetilena (PTFE) $0,45 \mu \mathrm{m}$, penyaring syringe politetrafluoroetilena (PTFE) 0,45 $\mu \mathrm{m}$, labu tentukur 10, 25, 50, 100, 500, $1000 \mathrm{ml}$ (Oberoi), pipet volume 1, 2, 3, 5, $10 \mathrm{ml}$ (Oberoi), gelas ukur 10, 50, dan $100 \mathrm{ml}$ (Oberoi), serta alat-alat gelas yang biasa digunakan di Laboratorium Penelitian

\subsubsection{Bahan Penelitian}

Bahan yang digunakan adalah metanol Grade HPLC (E. Merck), kalium dihidrogen fosfat anhidrat (E. Merck), asam orthofosfat (E. Merck), aqua bidestilata steril (Ekapharmindo Putramas), bahan baku natrium sakarin, natrium siklamat, natrium benzoat, kalium sorbat, tartrazin, dan sunset yellow (Sigma Aldrich), sampel sirup esens, sirup uji akurasi dan presisi.

\subsection{ChemStation Software}

Agilent 1290 Infinity Diode Array Detector dilengkapi dengan ChemStation Software 04.03.016, sehingga set up parameter optimasi dapat dilakukan, antara lain: volume void, panjang gelombang, sistem elusi fase gerak, laju alir dan suhu kolom. 
ChemStation Software 04.03.016 memberikan beberapa tipe laporan. Tipe Performance untuk metode y ang belum dikalibrasi berupa deskripsi sinyal, waktu retensi, luas puncak, tinggi puncak, lebar puncak, faktor simetri, faktor kapasitas, jumlah plat teoritis, selektivitas dan resolusi. Untuk metode y ang dikalibrasi, selain laporan metode yang belum dikalibrasi juga disertai dengan nama senyawa untuk masing-masing puncak. Sedangkan faktor tailing harus menggunakan tipe Performance plus Extended.

\subsection{S ampel Sirup Esens}

Sampel sirup esens diperoleh dengan cara melakukan survei komposisi bahan pemanis, pengawet dan pewarna sirup esens y ang terdapat di Kota Medan. Survei dilakukan dengan mendata merek sirup dan komposisi bahan pemanis, pengawet dan pewarna yang digunakan dari supermarket dan grosir terbesar di Kota Medan pada bulan Juli 2012. Dari hasil survei tersebut dilakukan pemilihan sampel berdasarkan kandungan senyawa yang diuji. Pengambilan sampel dilakukan sebanyak tiga botol dengan nomor bets yang sama untuk setiap merek y ang dipilih dan direncanakan enam merek sirup esens y ang akan digunakan untuk pengujian metode analisis dengan diberi kode $\mathrm{H}, \mathrm{I}, \mathrm{J}, \mathrm{K}, \mathrm{L}$ dan $\mathrm{M}$.

\subsection{Sirup Uji Akurasi dan Presisi}

Sirup y ang digunakan untuk uji akurasi dan presisi dari sirup X. Komposisi sirup $\mathrm{X}$ dari label kemasan tidak men gandung bahan tambahan pemanis, pengawet dan pewarna. Sirup X diperkirakan mengandung matriks yang lebih kompleks, selain mengandung bahan penstabil yang biasa digunakan dalam pembuatan sirup juga mengandung matriks dari sari buah asli. Spesifikasi sampel dan sirup X dapat dilihat pada Lampiran 2, halaman 107. 


\subsection{Rancangan Penelitian}

Penelitian tahap optimasi metode dilakukan dengan enam perlakuan dan tiga ulangan. Perlakuan terdiri atas:

$\mathrm{O}_{1}=$ Volume Void

$\mathrm{Q}_{2}=$ Volume Void + Panjang gelombang

$\mathrm{O}_{3}=$ Volume Void + Panjang gelombang $+\mathrm{pH}$ fase gerak

$\mathrm{O}_{4}=$ Volume Void + Panjang gelomban $\mathrm{g}+\mathrm{pH}$ fase gerak + Komposisi fase gerak

$\mathrm{O}_{5}=$ Volume Void + Panjang gelombang $+\mathrm{pH}$ fase gerak + Komposisi fase gerak

+ Laju alir

$\mathrm{O}_{6}=$ Volume Void + Panjang gelombang $+\mathrm{pH}$ fase gerak + Komposisi fase gerak

+ Laju alir + Suhu kolom.

\subsection{Parameter Penelitian}

Parameter yang digunakan pada penelitian meliputi parameter optimasi kondisi KCKT dan parameter validasi. Optimasi kondisi KCKT dilakukan dengan parameter: faktor kapasitas $\left(\mathrm{k}^{\prime}\right)$, waktu retensi $\left(\mathrm{t}_{\mathrm{R}}\right)$, faktor tailing $(\mathrm{Ft})$, resolusi $\left(\mathrm{R}_{\mathrm{s}}\right)$ dan jumlah plat teoritis $(\mathrm{N})$. Validasi meliputi: linearitas, batas deteksi (limit of detection), batas kuantitasi (limit of quantitation), akurasi (accuracy), ketelitian (precision) dan selektivitas (specifity). 


\subsection{Prosedur Penelitian}

\subsubsection{Pembuatan Larutan}

\subsubsection{Pembuatan Larutan Asam Fosfat 10 mM}

Sejumlah $0,34 \mathrm{ml}$ asam orthofosfat $85 \% \quad(\rho=1,685 \mathrm{~g} / \mathrm{ml})$ dimasukkan ke dalam labu $500 \mathrm{ml}$. Larutan diencerkan dengan penambahan aqua bidestilata steril sampai garis tanda (Larutan B) (Snyder, et al., 2010).

\subsubsection{Pembuatan Larutan Buffer Fosfat pH 4,7}

Ditimbang seksama sejumlah 1,3601 gram kalium dihidrogen fosfat anhidrat, dimasukkan ke dalam labu $1000 \mathrm{ml}$ dan ditambah aqua bidestilata steril sampai garis tanda. Larutan dipindahkan ke beaker gelas, diukur dan diperoleh $\mathrm{pH}$ 4,7 \pm 0,1 menggunakan $\mathrm{pH}$ meter (Snyder, et al., 2010). Larutan buffer fosfat kemudian disaring menggunakan peny aring selulosa nitrat $0,45 \mu \mathrm{m}$ dan disonikasi menggunakan alat sonikator selama 30 menit.

\subsubsection{Pembuatan Larutan Buffer Fosfat pH 4,5}

Ditimbang seksama sejumlah 1,3601 gram kalium dihidrogen fosfat anhidrat, dimasukkan ke dalam labu $1000 \mathrm{ml}$ dan ditambah aqua bidestilata steril sampai garis tanda. Larutan dipindahkan ke beaker gelas dan ditambah larutan B sedikit demi sedikit sampai diperoleh $\mathrm{pH} 4,5 \pm 0,1$ menggunakan $\mathrm{pH}$ meter (Snyder, et al., 2010). Larutan buffer fosfat kemudian disaring menggunakan penyaring selulosa nitrat $0,45 \mu \mathrm{m}$ dan disonikasi menggunakan alat sonikator selama 30 menit. 


\subsubsection{Pembuatan Larutan Buffer Fosfat pH 4,3}

Ditimbang seksama sejumlah 1,3601 gram kalium dihidrogen fosfat anhidrat, dimasukkan ke dalam labu $1000 \mathrm{ml}$ dan ditambah aqua bidestilata steril sampai garis tanda. Larutan dipindahkan ke beaker gelas dan ditambah larutan B sedikit demi sedikit sampai diperoleh $\mathrm{pH} 4,3 \pm 0,1$ menggunakan $\mathrm{pH}$ meter (Snyder, et al., 2010). Larutan buffer fosfat kemudian disaring menggunakan penyaring selulosa nitrat $0,45 \mu \mathrm{m}$ dan disonikasi menggunakan alat sonikator selama 30 menit.

\subsubsection{Pembuatan Larutan Buffer Fosfat pH 4,0}

Ditimbang seksama sejumlah 1,3601 gram kalium dihidrogen fosfat anhidrat, dimasukkan ke dalam labu $1000 \mathrm{ml}$ dan ditambah aqua bidestilata steril sampai garis tanda. Larutan dipindahkan ke beaker gelas dan ditambah larutan B sedikit demi sedikit sampai diperoleh $\mathrm{pH} 4,0 \pm 0,1$ menggunakan $\mathrm{pH}$ meter (Snyder, et al., 2010). Larutan buffer fosfat kemudian disaring menggunakan penyaring selulosa nitrat $0,45 \mu \mathrm{m}$ dan disonikasi menggunakan alat sonikator selama 30 menit.

\subsubsection{Pembuatan Larutan Baku Induk Satu}

Larutan baku induk satu dibuat dengan cara menimbang sejumlah 0,0655 g natrium sakarin; 0,0503 $\mathrm{g}$ natrium siklamat; 0,0700 g natrium benzoat; 0,0575 g kalium sorbat; 0,0528 $\mathrm{g}$ tartrazin dan 0,0502 $\mathrm{g}$ sunset yellow. Masing-masing larutan baku dimasukkan ke dalam labu ukur $50 \mathrm{ml}$, kecuali tartrazin dan natrium siklamat dalam labu ukur $10 \mathrm{ml}$ dan ditambah aqua bidestilata steril sampai garis tanda (LBI1). 


\subsubsection{Pembuatan Larutan Baku Induk Dua}

Larutan baku induk dua dibuat dengan cara menimbang sejumlah 0,0503 g natrium sakarin; 0,0501 $\mathrm{g}$ natrium siklamat; 0,0504 $\mathrm{g}$ natrium benzoat; 0,0501 $\mathrm{g}$ kalium sorbat; 0,0501 g tartrazin dan 0,0502 $\mathrm{g}$ sunset yellow. Masing-masing larutan baku dimasukkan ke dalam labu tentukur $50 \mathrm{ml}$ dan ditambah aqua bidestilata steril sampai garis tanda (LBI2).

\subsubsection{Pembuatan Larutan Baku Tunggal}

Ke dalam enam labu ukur $10 \mathrm{~mL}$ dimasukkan $0,1 \mathrm{ml}$ LBI2 masing-masing natrium sakarin, natrium benzoat, kalium sorbat, tartrazin dan sunset yellow serta 1,0 ml LB2 natrium siklamat, diencerkan dengan campuran buffer fosfat $\mathrm{pH} 4,5$ dan metanol (75:25) sampai batas tanda (LBT).

\subsubsection{Pembuatan Larutan Baku Tunggal Seri}

Ke dalam labu ukur $50 \mathrm{~mL}$ dimasukkan $0,5 \mathrm{ml}$ LBI1 natrium sakarin dan diencerkan dengan aqua bidestilata steril sampai garis tanda sehingga diperoleh konsentrasi 13,1 ppm (LBTS1). Kemudian dipipet secara seri dari larutan LBTS1 natrium sakarin sebanyak $8 \mathrm{ml}, 6 \mathrm{ml}, 4 \mathrm{ml}$ dan $2 \mathrm{ml}$, diencerkan dengan aqua bidestilata steril sampai $10 \mathrm{ml}$ sehingga diperoleh LBTS2, LBTS3, LBTS4 dan LBTS5 natrium sakarin. Dilakukan hal y ang sama untuk natrium benzoat, kalium sorbat dan sunset yellow.

Ke dalam labu ukur $50 \mathrm{~mL}$ dimasukkan $1 \mathrm{ml}$ LBI1 natrium siklamat dan diencerkan dengan aqua bidestilata steril sampai garis tanda sehingga diperoleh konsentrasi 100,6 ppm (LBTS1). Kemudian dipipet secara seri dari LBTS1 
natrium siklamat sebanyak $9 \mathrm{ml}, 8 \mathrm{ml}, 7 \mathrm{ml}$ dan $6 \mathrm{ml}$, diencerkan dengan aqua bidestilata steril sampai $10 \mathrm{ml}$ sehingga diperoleh LBTS2, LBTS3, LBTS4 dan LBTS5 natrium siklamat.

Ke dalam labu ukur 50 mL dimasukkan 1 ml LBI1 tartrazin dan diencerkan dengan aqua bidestilata steril sampai garis tanda sehingga diperoleh konsentrasi 105,6 ppm (LBTS1). Kemudian dipipet secara seri dari LBTS1 tartrazin sebanyak $8 \mathrm{ml}, 6 \mathrm{ml}, 4 \mathrm{ml}$ dan $2 \mathrm{ml}$, diencerkan dengan aqua bidestilata steril sampai $10 \mathrm{ml}$ sehingga diperoleh LBTS2, LBTS3, LBTS4 dan LBTS5 tartrazin.

\subsubsection{Pembuatan Larutan Baku Campuran}

Ke dalam labu ukur $10 \mathrm{~mL}$ dimasukkan larutan LBI2, masing-masing 0,32 $\mathrm{ml}$ natrium sakarin; 3,5 $\mathrm{ml}$ natrium siklamat; $0,6 \mathrm{ml}$ natrium benzoat; 0,6 ml kalium sorbat; $0,5 \mathrm{ml}$ tartrazin dan $0,2 \mathrm{ml}$ sunset yellow. Kemudian diencerkan dengan campuran buffer fosfat $\mathrm{pH} 4,5$ dan metanol (75:25) sampai batas tanda (LBC).

\subsubsection{Pembuatan Larutan Baku Campuran Seri}

Ke dalam labu ukur $10 \mathrm{~mL}$ dimasukkan $0,1 \mathrm{ml}, 0,2 \mathrm{ml}, 0,4 \mathrm{ml}, 0,6 \mathrm{ml}, 0,8$ $\mathrm{ml}, 1,0 \mathrm{ml}, 1,4 \mathrm{ml}, 2,0 \mathrm{ml}$ dan 2,8 $\mathrm{ml} \mathrm{LBC}$, kemudian masing-masing diencerkan dengan campuran buffer fosfat $\mathrm{pH} 4,5$ dan metanol (75:25) sampai batas tanda sehingga diperoleh larutan baku seri LBS1, LBS2, LBS3, LBS4, LBS5, LBS6, LBS7, LBS8 dan LBS9.

Ke dalam labu ukur 10 mL dimasukkan larutan LBI2, masing-masing 0,1 $\mathrm{ml}$ natrium sakarin; 7,5 ml natrium siklamat; $0,3 \mathrm{ml}$ natrium benzoat; $0,6 \mathrm{ml}$ 
kalium sorbat; $1 \mathrm{ml}$ tartrazin dan $0,5 \mathrm{ml}$ sunset yellow (LBCO). Kemudian $1 \mathrm{ml}$ LBCO dimasukkan ke dalam labu ukur 10 dan diencerkan dengan campuran buffer fosfat $\mathrm{pH} 4,5$ dan metanol (75:25) sampai batas tanda sehingga diperoleh larutan baku seri 10 (LBS10).

\subsubsection{Penentuan Panjang Gelombang Maksimum}

Tahap ini untuk menentukan panjang gelombang yang akan digunakan pada detektor KCKT. Pengukuran absorbansi dilakukan LBTS1 - LBTS5 dari masingmasing senyawa. Masing-masing larutan diukur pada 190 - $600 \mathrm{~nm}$ menggunakan spektrofotometer UV-Vis. Spektrum yang diperoleh dianalisis untuk menentukan panjang gelombang maksimum yang digunakan untuk analisis selanjutnya dari keenam seny awa tersebut.

\subsubsection{Optimasi Metode KCKT}

\subsubsection{Optimasi Volume Void}

Tahap ini dilakukan untuk mengetahui volume void. Percobaan dilakukan dengan menyaring larutan LBS10 dengan penyaring syringe PTFE 0,45 $\mu \mathrm{m}$, disonikasi selama 15 menit. Kemudian diinjeksikan $5 \mu$ LBS 10 ke dalam kolom dengan menggunakan panjang gelombang $200 \mathrm{~nm}$, laju alir 0,8 ml/menit, suhu kolom $30^{\circ} \mathrm{C}$, komposisi campuran buffer fosfat dan metanol (75:25), pH fase gerak 4,5 dan volume void y ang diuji adalah $20 \%, 30 \%$ dan $40 \%$. Selanjutnya dipilih kondisi yang memberikan hasil optimum. Parameter yang dipakai untuk menetapkan kondisi percobaan adalah faktor kapasitas (k'). 


\subsubsection{Optimasi Panjang Gelombang}

Tahap ini dilakukan untuk mengetahui panjang gelombang optimum. Percobaan dilakukan dengan menyaring larutan LBS10 dengan penyaring syringe PTFE 0,45 $\mu \mathrm{m}$, disonikasi selama 15 menit. Kemudian diinjeksikan $5 \mu 1$ LBS10 ke dalam kolom dengan menggunakan volume void hasil optimasi, laju alir 0,8 $\mathrm{ml} / \mathrm{menit}$, suhu kolom $30^{\circ} \mathrm{C}$, komposisi campuran buffer fosfat dan metanol (75 : 25), $\mathrm{pH}$ fase gerak 4,5 dan panjang gelombang y ang diuji adalah $200 \mathrm{~nm}, 220 \mathrm{~nm}$ $240 \mathrm{~nm}$ dan $440 \mathrm{~nm}-470 \mathrm{~nm}$ dengan range $10 \mathrm{~nm}$. Selanjutnya dipilih kondisi yang memberikan hasil optimum. Parameter yang dipakai untuk menetapkan kondisi percobaan adalah faktor tailing (tR') dan tinggi serapan.

\subsubsection{Optimasi pH Fase Gerak}

Tahap ini untuk memperoleh $\mathrm{pH}$ larutan buffer fosfat yang memberikan pemisahan senyawa dengan baik. Percobaan dilakukan dengan menyaring larutan LBS10 dengan penyaring syringe PTFE $0,45 \mu \mathrm{m}$, disonikasi selama 15 menit. Kemudian diinjeksikan $5 \mu 1$ LBS10 ke dalam kolom dengan menggunakan volume void, panjang gelombang hasil optimasi, laju alir $0,8 \mathrm{ml} / \mathrm{menit}$, suhu kolom $30^{\circ} \mathrm{C}$, fase gerak campuran buffer fosfat dan metanol $(75: 25)$ dan $\mathrm{pH}$ fase gerak yang diuji adalah 4,0;4,3; 4,5 dan 4,7. Selanjutnya dipilih kondisi yang memberikan hasil optimum. Parameter yang dipakai untuk menetapkan kondisi percobaan adalah waktu retensi, faktor kapasitas, faktor tailing, resolusi dan jumlah plat teoritis. 


\subsubsection{Optimasi Komposisi Fase Gerak}

Tahap ini untuk menentukan komposisi fase gerak optimum yang memberikan pemisahan senyawa dengan baik. Percobaan dilakukan dengan menyaring larutan LBS10 dengan penyaring syringe PTFE 0,45 $\mu \mathrm{m}$, disonikasi selama 15 menit. Kemudian diinjeksikan $5 \mu$ LBS10 ke dalam kolom dengan menggunakan volume void, panjang gelombang dan $\mathrm{pH}$ fase gerak hasil optimasi, laju alir $0,8 \mathrm{ml} / \mathrm{menit}$ dan suhu kolom $30^{\circ} \mathrm{C}$. Komposisi campuran buffer fosfat dan metanol y ang diuji adalah $73: 27 ; 75: 25$ dan $77: 23$. Selanjutny a dipilih kond isi yang memberikan hasil optimum. Parameter yang dipakai untuk menetapkan kondisi percobaan adalah waktu retensi, faktor kapasitas, faktor tailing, resolusi dan jumlah plat teoritis.

\subsubsection{Optimasi Laju Alir}

Tahap ini bertujuan untuk menentukan laju alir optimum yang memberikan pemisahan senyawa dengan baik. Percobaan dilakukan dengan menyaring larutan LBS10 dengan penyaring syringe PTFE $0,45 \mu \mathrm{m}$, disonikasi selama 15 menit. Kemudian diinjeksikan $5 \mu$ LBS10 ke dalam kolom den gan men ggunakan volume void, panjang gelombang, komposisi dan $\mathrm{pH}$ fase gerak hasil optimasi den gan suhu kolom $30^{\circ} \mathrm{C}$. Laju alir yang diuji adalah 0,$8 ; 1,0$ dan $1,2 \mathrm{ml} / \mathrm{menit}$. Selanjutnya dipilih kondisi yang memberikan hasil optimum. Parameter yang dipakai untuk menetapkan kondisi percobaan adalah waktu retensi, faktor kapasitas, faktor tailing, resolusi dan jumlah plat teoritis. 


\subsubsection{Optimasi Suhu Kolom}

Tahap ini bertujuan untuk menentukan suhu kolom optimum yang memberikan pemisahan senyawa dengan baik. Percobaan dilakukan dengan menyaring larutan LBS10 dengan penyaring syringe PTFE $0,45 \mu \mathrm{m}$, disonikasi

selama 15 menit. Kemudian diinjeksikan $5 \mu$ LBS10 ke dalam kolom menggunakan volume void, panjang gelombang, komposisi dan $\mathrm{pH}$ fase gerak dan laju alir hasil optimasi. Suhu kolom yang diuji adalah $25^{\circ} \mathrm{C}, 30^{\circ} \mathrm{C}$ dan $35^{\circ} \mathrm{C}$. Selanjutnya dipilih kondisi yang memberikan hasil optimum. Parameter yang dipakai untuk menetapkan kondisi percobaan adalah waktu retensi, faktor kapasitas, faktor tailing, resolusi dan jumlah plat teoritis.

\subsubsection{Penentuan Waktu Retensi Senyawa}

Tahap ini dilakukan untuk mengetahui waktu retensi setiap senyawa. Larutan LBT disaring dengan penyaring syringe PTFE $0,45 \mu \mathrm{m}$, disonikasi selama 15 menit. Penentuan waktu retensi dilakukan dengan menginjeksikan $5 \mu \mathrm{L}$ LBT. Kondisi pengujian adalah volume void $30 \%$, suhu oven $30^{\circ} \mathrm{C}$, fase gerak buffer fosfat $\mathrm{pH} 4,5$ dan metanol $(75: 25)$, laju alir $1,0 \mathrm{ml} /$ menit dengan tiga panjang gelombang deteksi hasil optimasi. Waktu retensi setiap senyawa yang diperoleh merupakan karakteristik untuk identifikasi senyawa. 


\subsubsection{Validasi Metode KCKT}

Hasil optimasi metode kemudian divalidasi dengan parameter yang meliputi: linearitas, batas deteksi, batas kuantitasi, akurasi, presisi dan selektivitas.

\subsubsection{Linearitas}

Masing-masing larutan baku seri (LBS) disaring dengan penyaring syringe PTFE 0,2 $\mu \mathrm{m}$ dan disonikasi selama 15 menit. Larutan LBS1 diinjeksikan sebanyak $5 \mu \mathrm{L}$, kemudian dibiarkan sampai semua komponen keluar dan terpisah dari kolom. Langkah tersebut diulangi dengan menginjeksikan $5 \mu 1$ LBS1, LBS2, LBS3, LBS4, LBS5, LBS6, LBS7, LBS8 dan LBS9. Kemudian diplot hubungan antara konsentrasi larutan baku (X) dengan luas area $(\mathrm{Y})$ dari masing-masing komponen, ditentukan persamaan linear $Y=a+b X$, dihitung koefisien korelasi (r), batas deteksi (LOD) dan batas kuantitasi (LOQ). Batas deteksi dan batas kuantitasi masing-masing dihitung dengan persamaan $\mathrm{LOD}=3 \mathrm{SD} / \mathrm{b}$ dan $\mathrm{LOQ}=$ 10SD/b (Ravichandran, et al., 2010; Chan, et al., 2004; Harmita, 2004; Huber, 1999).

\subsubsection{Akurasi}

Uji kecermatan dilakukan dengan menggunakan metode penambahan bahan baku (standard addition method). Pen gujian akurasi dilakukan pada rentang $80 \%, 100 \%$ dan $120 \%$. Larutan sirup X (LS) dibuat dengan cara menimbang sejumlah 5,0128 g sirup X, dimasukkan ke dalam labu ukur $50 \mathrm{ml}$ dan ditambah aqua bidestilata steril sampai garis tanda, sehingga dalam $1 \mathrm{ml}$ larutan LS men gandung 0,1003 gram sirup $X$. 
Untuk pengujian sirup dilakukan dengan memipet $1 \mathrm{ml} \mathrm{LS}$, dimasukkan ke dalam sebuah labu ukur $10 \mathrm{ml}$, diencerkan dengan campuran buffer fosfat $\mathrm{pH}$ 4,5 dan metanol (75 : 25) sampai batas tanda, disaring den gan peny aring syring e PTFE 0,45 $\mu \mathrm{m}$, disonikasi selama 15 menit dan diinjeksikan $5 \mu \mathrm{l} \mathrm{ke} \mathrm{dalam} \mathrm{alat} \mathrm{KCKT}$ dengan kondisi sesuai hasil optimasi.

Akurasi $80 \%$ dilakukan dengan penambahan $0,8 \mathrm{ml}$ LBC ke dalam $1 \mathrm{ml}$ LS, dimasukkan ke dalam sebuah labu ukur $10 \mathrm{ml}$, diencerkan den gan campuran buffer fosfat $\mathrm{pH} 4,5$ dan metanol (75:25) sampai batas tanda. Larutan tersebut disaring dengan peny aring syring e PTFE $0,45 \mu \mathrm{m}$, disonikasi selama 15 menit dan diinjeksikan $5 \mu \mathrm{l}$ ke dalam alat KCKT dengan kondisi sesuai hasil optimasi.

Akurasi 100\% dilakukan dengan penambahan $1 \mathrm{ml} \mathrm{LBC}$ ke dalam $1 \mathrm{ml} \mathrm{LS}$, dimasukkan ke dalam sebuah labu ukur $10 \mathrm{ml}$, diencerkan den gan campuran buffer fosfat $\mathrm{pH} 4,5$ dan metanol $(75: 25)$ sampai batas tanda. Larutan tersebut disaring dengan penyaring syringe PTFE $0,45 \mu \mathrm{m}$, disonikasi selama 15 menit dan diinjeksikan $5 \mu \mathrm{l}$ ke dalam alat KCKT dengan kondisi sesuai hasil optimasi.

Akurasi 120\% dilakukan dengan penambahan 1,2 ml LBC ke dalam $1 \mathrm{ml}$ LS, dimasukkan ke dalam sebuah labu ukur $10 \mathrm{ml}$, diencerkan dengan campuran buffer fosfat $\mathrm{pH} 4,5$ dan metanol (75:25) sampai batas tanda. Larutan tersebut disaring dengan peny aring syring e PTFE $0,45 \mu \mathrm{m}$, disonik asi selama 15 men it dan diinjeksikan $5 \mu 1$ ke dalam alat KCKT dengan kondisi sesuai hasil optimasi.

Perhitungan konsentrasi senyawa dalam larutan sirup X, akurasi $80 \%$, akurasi 100\% dan akurasi 120\% menggunakan persamaan regresi masing-masing senyawa. Kemudian dihitung konsentrasi senyawa dalam sirup dengan menggunakan rumus $\mathrm{M}=\mathrm{c} / \mathrm{W} \times \mathrm{Fp} / 1000 \mathrm{x}$ k. Selisih konsentrasi senyawa dalam 
akurasi $80 \%, 100 \%$ dan $120 \%$ dengan sirup $\mathrm{X}\left(\mathrm{C}_{1}-\mathrm{C}_{2}\right)$ dibandingkan dengan konsentrasi senyawa baku yang sebenarny a ditambahkan $\left(\mathrm{C}_{3}\right)$. Hasil perhitungan akurasi dinyatakan sebagai persen perolehan kembali, dihitung dengan persamaan persentase recovery sebesar $\left[\left(\mathrm{C}_{1}-\mathrm{C}_{2}\right) / \mathrm{C}_{3}\right] \mathrm{x} 100 \%$ (Ravichandran, et al., 2010; Chan, et al., 2004; Harmita, 2004; Huber, 1999).

\subsubsection{Presisi}

Uji keseksamaan dilakukan sebagai uji ripitabilitas (URI) dan uji reprodusibilitas (URE). Uji uji ripitabilitas dilakukan dengan cara meny untikkan 8 $\mu$ L LBS 10 sebanyak 6 kali ulangan pada kondisi sistem KCKT yang diperoleh sesuai den gan hasil optimasi.

Pengujian reprodusibilitas dilakukan dengan cara menyuntikkan $5 \mu \mathrm{L}$ campuran larutan sirup $X$ dengan LBC. Larutan sirup $X$ (LS) dipipet $1 \mathrm{ml}$ dan dicampur dengan 1,2 $\mathrm{ml}$ LBC dalam labu ukur $10 \mathrm{ml}$ dan diencerkan dengan campuran buffer fosfat $\mathrm{pH} 4,5$ dan metanol (75:25) sampai batas tanda, disaring dengan penyaring syringe PTFE $0,45 \mu \mathrm{m}$, disonikasi selama 15 menit dan diinjeksikan $5 \mu \mathrm{l}$ ke dalam alat KCKT dengan ulangan sebanyak 6 kali pada kondisi sistem KCKT y ang diperoleh sesuai den gan hasil optimasi.

Data yang diperoleh setiap injeksi digunakan untuk menentukan keterulan gan metode dan ketertiruan metode y ang diny atakan sebagai persen RSD dari luas area. Dihitung standar deviasi (SD), kadar rata-rata $(\bar{X})$ dan persentase RSD sebesar (SD/ $\bar{X}) \times 100 \%$ (Ravichandran, et al., 2010; Chan, et al., 2004; Harmita, 2004; Burn, et al., 2002; Huber, 1999). 


\subsubsection{Selektivitas}

Uji selektivitas dilakukan dengan membandingkan kromatogram larutan baku, larutan sirup $\mathrm{X}$ dan larutan sirup $\mathrm{X}$ ditambah baku. Kromatogram larutan baku, larutan sirup $\mathrm{X}$ dan larutan sirup $\mathrm{X}$ ditambah baku harus menunjukkan waktu retensi relatif sama dengan waktu retensi masing-masing senyawa. Kondisi pengujian menggunakan metode KCKT sesuai hasil optimasi.

Larutan sirup X ditambah baku dibuat sesuai prosedur pengujian 100\% pada uji akurasi. Larutan sirup X ditambah baku dibuat dengan cara menambahan $1 \mathrm{ml} \mathrm{LBC} \mathrm{ke} \mathrm{dalam} 1 \mathrm{ml}$ LS, dimasukkan ke dalam sebuah labu tentukur $10 \mathrm{ml}$, diencerkan dengan campuran buffer fosfat $\mathrm{pH} 4,5$ dan metanol (75:25) sampai batas tanda. Larutan tersebut disaring dengan penyaring syringe PTFE $0,45 \mu \mathrm{m}$, disonikasi selama 15 menit dan diinjeksikan $5 \mu$ l ke dalam alat KCKT dengan kondisi sesuai hasil optimasi.

Larutan sirup X dibuat sesuai prosedur pengujian sirup X pada uji akurasi. Larutan sirup $\mathrm{X}$ dibuat dengan memipet $1 \mathrm{ml} \mathrm{LS}$, dimasukkan ke dalam sebuah labu ukur $10 \mathrm{ml}$, diencerkan dengan campuran buffer fosfat $\mathrm{pH}$ 4,5 dan metanol (75 : 25) sampai batas tanda, disaring dengan penyaring syringe PTFE $0,45 \mu \mathrm{m}$, disonikasi selama 15 menit dan diinjeksikan $5 \mu 1$ ke dalam alat KCKT dengan kondisi sesuai hasil optimasi.

Larutan baku dibuat dilakukan dengan memipet $1 \mathrm{ml}$ LBC, dimasukkan ke dalam sebuah labu tentukur $10 \mathrm{ml}$, diencerkan dengan campuran buffer fosfat $\mathrm{pH}$ 4,5 dan metanol (75:25) sampai batas tanda, disaring dengan penyaring syringe PTFE 0,45 $\mu \mathrm{m}$, disonikasi selama 15 menit dan diinjeksikan $5 \mu$ l ke dalam alat KCKT dengan kondisi sesuai hasil optimasi. 


\subsubsection{Penetapan Kadar Pemanis, Pengawet dan Pewarna dalam Sampel}

Ditimbang seksama 1,0 gram sampel, diencerkan sampai volumenya tepat $10 \mathrm{~mL}$, disonikasi selama 30 menit. Larutan dipipet sebanyak $1 \mathrm{ml}$ kemudian dimasukkan ke dalam labu ukur $10 \mathrm{ml}$. Larutan disaring dengan peny aring syringe PTFE $0,45 \mu \mathrm{m}$ ke dalam vial autosampler dan diinjeksikan sebanyak $5 \mu 1$ ke alat KCKT dengan metode sesuai hasil optimasi. Perlakuan tersebut dilakukan sebanyak tiga kali ulangan. Kadar senyawa dihitung berdasarkan persamaan regresi masing-masing senyawa yang sudah diperoleh. Kadar dinyatakan dalam milligram per kilogram setiap senyawa dalam sampel dihitung dengan persamaan berikut (Wrolstad, et al., 2005):

$$
M=\frac{c}{W} \times \frac{F p}{1000} \times k
$$

Kadar dinyatakan dalam persen massa per massa setiap senyawa dalam sampel dihitung den gan persamaan berikut (Wrolstad, et al., 2005):

$$
P=\frac{M}{10^{6}} \times 100 \%
$$

Di mana: $\mathrm{M}$ = Kadar rata-rata BTM $(\mathrm{mg} / \mathrm{kg})$

$\mathrm{c}=$ Kadar rata-rata BTM dari peny untikan $(\mu \mathrm{g} / \mathrm{ml})$

$\mathrm{W}=$ Massa rata-rata penimbangan sampel $(\mathrm{kg})$

Fp $=$ Faktor Pengenceran

$\mathrm{k}=$ Angka kemurnian bah an baku (\%)

$\mathrm{P}=$ Kadar rata-rata BTM $(\%)$ 


\section{BAB IV}

\section{HASIL DAN PEMBAHASAN}

\subsection{Panjang Gelombang Maksimum}

Penentuan panjang gelombang maksimum yang telah dilakukan menunjukkan bahwa setiap senyawa memiliki panjang gelombang maksimum y ang berbeda-beda. Panjang gelombang maksimum hasil penelitian untuk natrium siklamat, natrium sakarin, natrium benzoat, kalium sorbat, tartrazin dan sunset yellow masing-masing sebesar: 197, 201, 224, 254, 427 dan 482 nm. Spektrum masing-masing senyawa baku dapat dilihat pada Lampiran 3, halaman 108 - 110. Spektrum overlay enam seny awa baku dapat dilihat pada Gambar 4.1.

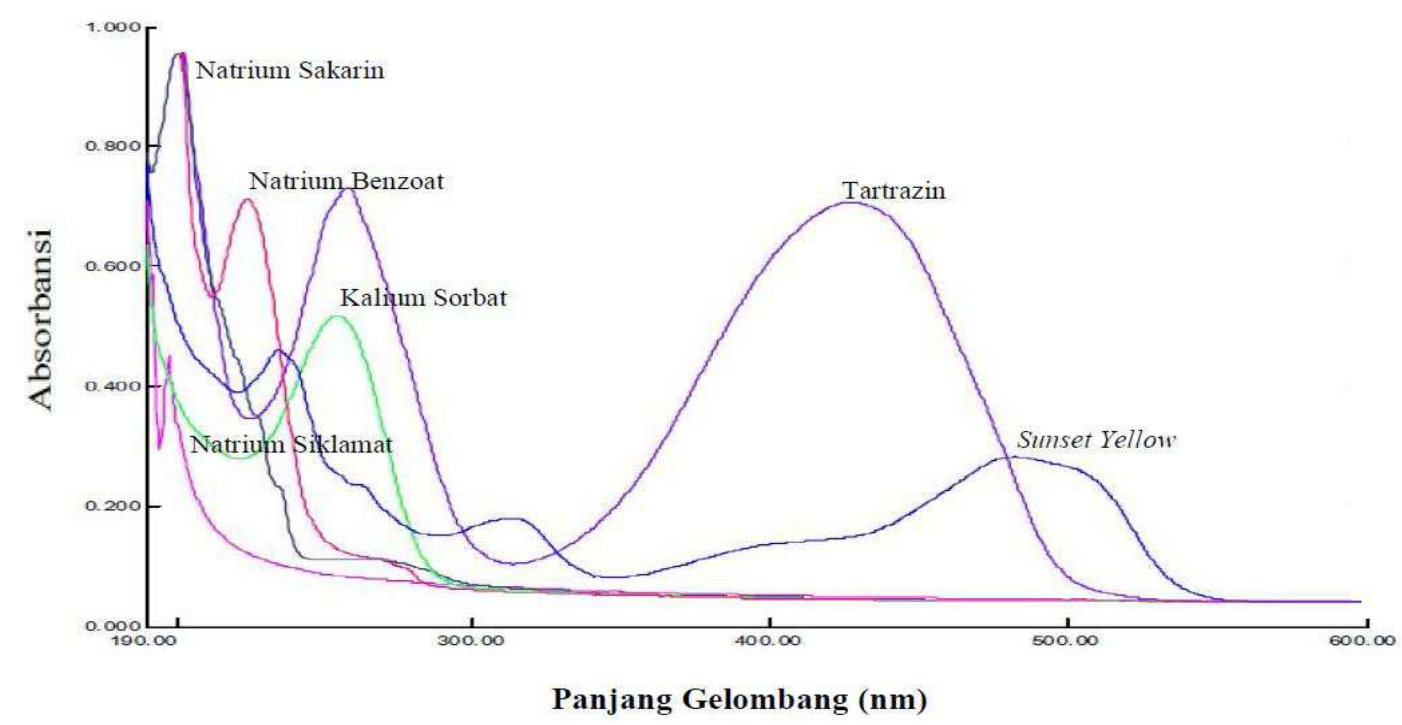

Gambar 4.1 Spektrum Overlay Enam Seny awa Baku

Panjang gelombang maksimum natrium sakarin yang diperoleh dari hasil penelitian yang dilakukan oleh peneliti sebelumnya adalah $200 \mathrm{~nm}, 202 \mathrm{~nm}$ dan 204 nm (Serdar dan Knezevic, 2011; Xiao, et al., 2011; Lin, et al., 2000). Hal ini memberikan informasi bahwa panjang gelombang maksimum natrium sakarin 
berada pada rentang $200 \mathrm{~nm}$ - $204 \mathrm{~nm}$. Dengan demikian, hasil penelitian penentuan panjang gelombang maksimum natrium sakarin $201 \mathrm{~nm}$ dinyatakan berada pada rentang hasil penelitian yang dilakukan oleh peneliti sebelumnya.

Panjang gelombang maksimum natrium siklamat yang diperoleh dari hasil penelitian yang dilakukan oleh peneliti sebelumnya adalah $194 \mathrm{~nm}$ dan $205 \mathrm{~nm}$ (Xiao , et al., 2011; Zhihong dan Yanchun, 1999). Berdasarkan hasil penelitian tersebut, maka panjang gelombang maksimum natrium siklamat berada pada rentang $194 \mathrm{~nm}-205 \mathrm{~nm}$. Dengan demikian, hasil penelitian penentuan panjang gelombang maksimum natrium siklamat $197 \mathrm{~nm}$ diny atakan berada pada rentang hasil penelitian y ang dilakukan oleh peneliti sebelumnya.

Panjang gelombang maksimum natrium benzoat yang diperoleh dari hasil penelitian yang dilakukan oleh peneliti sebelumnya adalah $224 \mathrm{~nm}, 225 \mathrm{~nm}, 227$ nm, 228 nm dan 230 nm (Esfandiari, et al., 2013; Ene dan Diacu, 2009; Nour, et al., 2009; Alghamdi, et al., 2005; Pylypiw dan Grether, 2000). Hasil penelitian ini memberikan informasi bahwa panjang gelombang maksimum natrium benzoat berada pada rentang $224 \mathrm{~nm}-230 \mathrm{~nm}$. Dengan demikian, hasil penelitian penentuan panjang gelombang maksimum natrium benzoat $224 \mathrm{~nm}$ dinyatakan berada pada rentang hasil penelitian yang dilakukan oleh peneliti sebelumny a dan sama dengan yang dilakukan oleh peneliti Alghamdi, et al. (2005).

Panjang gelombang maksimum kalium sorbat yang diperoleh dari hasil penelitian yang dilakukan oleh peneliti sebelumnya adalah $254 \mathrm{~nm}, 255 \mathrm{~nm}, 260$ nm dan $261 \mathrm{~nm}$ (Esfandiari, et al., 2013; Nour, et al., 2009; Tfouni dan Toledo, 2002; Pylypiw dan Grether, 2000). Hasil penelitian ini memberikan informasi bahwa panjang gelombang maksimum kalium sorbat berada pada rentang $254 \mathrm{~nm}$ 
- 261 nm. Dengan demikian, hasil penelitian penentuan panjang gelombang maksimum kalium sorbat $254 \mathrm{~nm}$ dinyatakan berada pada rentang hasil penelitian yang dilakukan oleh peneliti sebelumnya dan sama dengan yang dilakukan oleh peneliti Nour, et al. (2009).

Panjang gelombang maksimum tartrazin yang diperoleh dari hasil penelitian y ang dilakukan oleh peneliti sebelumnya adalah $426 \mathrm{~nm}, 427 \mathrm{~nm}, 429$ nm dan 431 nm (Ramakrishnan, et al., 2011; Vachirapatama, et al., 2008; Zatar, 2007; Lopez, et al., 1997). Hasil penelitian ini memberikan informasi bahwa panjang gelombang maksimum tartrazin berada pada rentang $426 \mathrm{~nm}-431 \mathrm{~nm}$. Dengan demikian, hasil penelitian penentuan panjang gelombang maksimum kalium sorbat $427 \mathrm{~nm}$ dinyatakan berada pada rentang hasil penelitian yang dilakukan oleh peneliti sebelumny a dan sama dengan yang dilakukan oleh peneliti Zatar (2007).

Panjang gelombang maksimum sunset yellow yang diperoleh dari hasil penelitian y ang dilakukan oleh peneliti sebelumnya adalah $480 \mathrm{~nm}, 481 \mathrm{~nm}, 484$ nm dan 487 nm (Pavanelli, et al., 2011; Vachirapatama, et al., 2008; Zatar, 2007; Lopez, et al., 1997). Hasil penelitian ini memberikan informasi bahwa panjang gelombang maksimum sunset yellow berada pada rentang $480 \mathrm{~nm}-487 \mathrm{~nm}$. Dengan demikian, hasil penelitian penentuan panjang gelombang maksimum sunset yellow $482 \mathrm{~nm}$ dinyatakan berada pada rentang hasil penelitian yang dilakukan oleh peneliti sebelumnya. 


\subsection{Tahap Optimasi}

\subsubsection{Optimasi Volume Void}

Pengaruh volume void terhadap parameter optimasi dapat dilihat pada Tabel 4.1. Hubungan volume void den gan faktor kapasitas dan selektifitas natrium sakarin, natrium siklamat, natrium benzoat, tartrazin dan sunset yellow dapat dilihat pada Gambar 4.2. Kromatogram optimasi volume void dapat dilihat pada Lampiran 5, halaman 112.

Tabel 4.1 Pengaruh Volume Void terhadap Parameter Optimasi

\begin{tabular}{|c|c|c|c|c|c|c|c|c|c|c|c|c|c|c|c|c|c|c|c|c|}
\hline \multirow{3}{*}{ No } & \multirow{3}{*}{ Senzara } & \multirow{3}{*}{$\begin{array}{c}\begin{array}{c}\text { Pagimg } \\
\text { Gelowbing } \\
\text { (mil) }\end{array} \\
\end{array}$} & \multicolumn{18}{|c|}{ 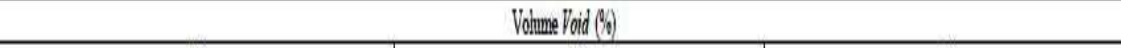 } \\
\hline & & & \multicolumn{6}{|c|}{20} & \multicolumn{6}{|c|}{30} & \multicolumn{6}{|c|}{$T_{T}$} \\
\hline & & & $\mathrm{Rt}$ & 1 & N & $R$ & a & fit & Rt & R & $\mathrm{N}$ & $R$ & a & $\mathrm{Ft}$ & Rit & k & $N$ & $\mathrm{R}$ & a & Ift \\
\hline ? & Tatazin & 200 & 1.236 & 1,980 & 158. & - & . & 1,193 & 1.237 & 0,990 & 1598 & 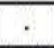 &. & 1,152 & 1,338 & 0,49 & 1707 & . & . & 1,229 \\
\hline ? & Nabium Satane & 200 & 1,95 & 3,630 & 6220 & 6,210 & 1.840 & 1.209 & 19,6 & 2,090 & 6040 & 6.80 & 21120 & 1.230 & 1,95 & 1,320 & 6404 & 6.340 & 2,690 & 1.200 \\
\hline 3 & Nabium Sildamet & 200 & 3,232 & 6,780 & 4765 & 9,150 & 1.870 & 2390 & 3,333 & 4,190 & 4966 & 9,230 & 2,000 & 1,714 & $3,23 !$ & 2890 & 5220 & 9,470 & 21.90 & 1,596 \\
\hline 4 & Sumbet Fellow & 200 & 4,659 & 10.210 & 2699 & 5,220 & 1510 & 1.767 & 4.664 & 6,490 & 3084 & 5500 & 1.550 & 1,293 & 4,662 & 4,610 & 2878 & 5,40 & 1,600 & 1,637 \\
\hline 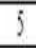 & Natrim Berzost & 200 & 7,209 & 16,350 & 11443 & 8,100 & 1,600 & 1,065 & 7,216 & 10,580 & 11298 & 8390 & 1,630 & 1,058 & 7212 & 7,680 & 12261 & 8,370 & 1,60 & 1077 \\
\hline 6 & Kalinm Sobati & 200 & 10,834 & 25,080 & 12410 & 10,990 & 1,530 & 1,115 & 10,846 & 16,400 & $124 !$ & 10,970 & 1,550 & $1,1,12$ & 10,837 & 12,040 & 12188 & 11,080 & 1,570 & 1051 \\
\hline
\end{tabular}

Keterangan: - = Tak terdeteksi
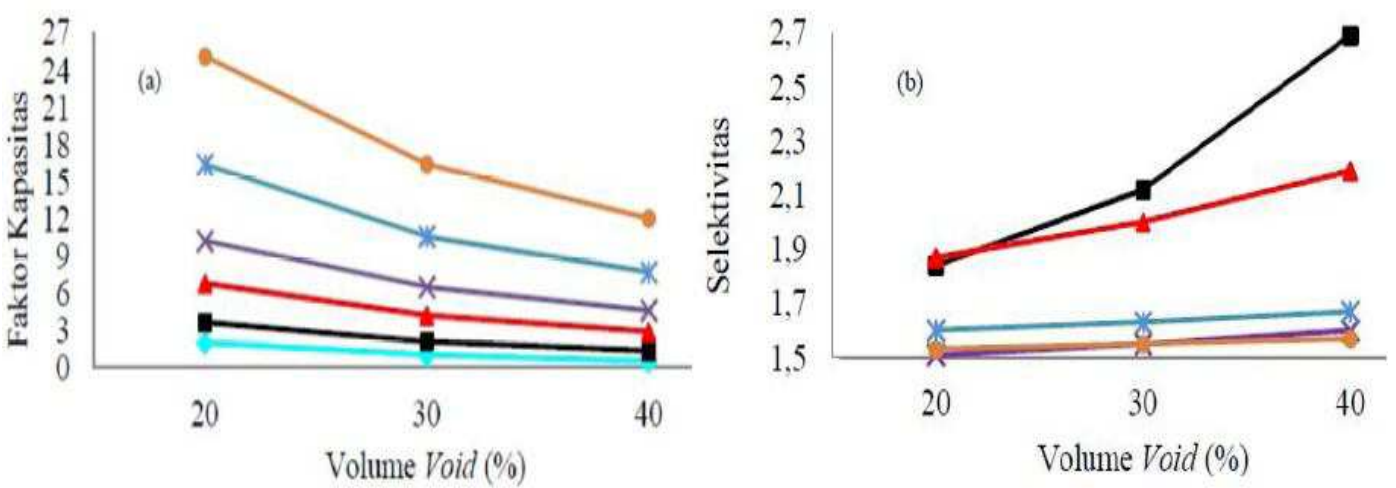

Gambar 4.2 Hubungan Volume Void den gan Faktor Kapasitas (a) dan Selektifitas (b) Natrium Sakarin (匹), Natrium Siklamat (^), Natrium Benzoat (*), Tartrazin $(\diamond)$ dan Sunset Yellow ( $\times$ )

Tabel 4.1 dan Gambar 4.2 memberikan informasi bahwa volume void san gat signifikan mempen garuhi faktor kapasitas dan selektifitas. Volume void semakin besar menyebabkan faktor kapasitas semakin kecil dan selektivitas semakin meningkat. Faktor kapasitas semakin menurun menunjukkan bahwa kelarutan 
natrium sakarin, natrium siklamat, natrium benzoat, kalium sorbat, tartrazin dan sunset yelllow dengan fase gerak semakin baik. Selektivitas semakin meningkat memberikan informasi bahwa pemisahan natrium sakarin, natrium siklamat, natrium benzoat, kalium sorbat, tartrazin dan sunset yellow semakin sempurna.

Hubungan volume void dengan faktor kapasitas dan tailing natrium siklamat dapat dilihat pada Gambar 4.3. Gambar 4.3 menunjukkan bahwa peningkatan volume void menyebabkan natrium siklamat mengalami penurunan faktor kapasitas dan faktor tailing. Hal ini menunjukkan bahwa partisi natrium siklamat dengan fase gerak semakin baik. Nilai faktor tailing natrium siklamat sebesar 2,390 (Tabel 4.1) pada volume void $20 \%$, lebih besar dari y ang diizinkan $(0,9 \leq \mathrm{Ft}$ $\leq 2,0)$. Hal ini menunjukkan bahwa partisi natrium siklamat dengan fase gerak kurang baik.

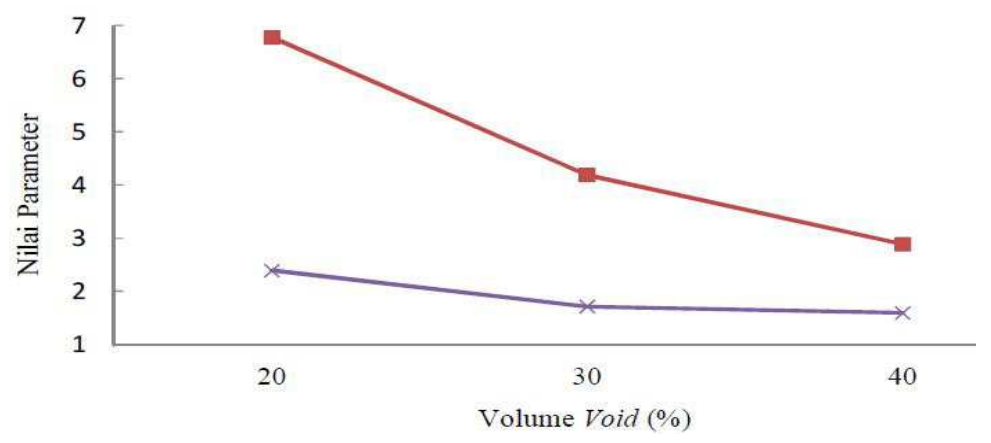

Gambar 4.3 Hubungan Volume Void dengan Faktor Kapasitas ( $\bullet$ ) dan Tailing $(\times)$ Natrium Siklamat

Dari Tabel 4.1 pada volume void $20 \%$ memberikan nilai $\mathrm{k}=25,08$ untuk kalium sorbat, melampaui batas maksimal yang diizinkan, namun kromatogram kalium sorbat tidak mengalami tailing. Hal ini menunjukkan bahwa kalium sorbat masih mampu berpartisi dengan fase gerak yang digunakan. Volume void $40 \%$ memberikan nilai $\mathrm{k}=0,490$ untuk tartrazin, di bawah batas minimal yang diizinkan. Data faktor kapasitas tersebut menunjukkan ada kemungkinan terjadi overlaping den gan pelarut y ang biasa menumpuk dekat $\mathrm{t}_{0}$. Sedan gk an volume void 
$30 \%$ memberikan nilai $\mathrm{k}$ antara 0,990 - 16,400; berada pada rentang yang diizinkan, sehingga penelitian dilanjutkan den gan men ggunak an volume void $30 \%$.

\subsubsection{Optimasi Panjang Gelombang}

Faktor tailing senyawa pada masing-masing panjang gelombang dapat dilihat pada Tabel 4.2. Kromatogram optimasi panjang gelombang dapat dilihat pada Lampiran 6, halaman 113 - 115.

Tabel 4.2 Faktor Tailing Seny awa pada Masing-Masing Panjang Gelombang

\begin{tabular}{|l|c|c|c|c|c|c|c|c|}
\hline \multirow{2}{*}{ Senyawa } & \multicolumn{7}{|c|}{ Faktor Tailing } \\
\cline { 2 - 10 } & $200 \mathrm{~nm}$ & $220 \mathrm{~nm}$ & $230 \mathrm{~nm}$ & $240 \mathrm{~nm}$ & $440 \mathrm{~nm}$ & $450 \mathrm{~nm}$ & $460 \mathrm{~nm}$ & $470 \mathrm{~nm}$ \\
\hline Tartrazin & 1.152 & 1,344 & 1.390 & 1,412 & 1.416 & 1,415 & 1.412 & 1.418 \\
\hline Natrium Sakarin & 1,230 & 1,224 & 1.237 & 1,232 & $\mathrm{tt}$ & $\mathrm{tt}$ & $\mathrm{tt}$ & $\mathrm{tt}$ \\
\hline Natrium Siklamat & 1,714 & $\mathrm{tt}$ & $\mathrm{tt}$ & $\mathrm{tt}$ & $\mathrm{tt}$ & $\mathrm{tt}$ & $\mathrm{tt}$ & $\mathrm{tt}$ \\
\hline Sunset Yellow & 1.293 & 1,586 & 1.636 & 1.645 & 1.604 & 1.629 & 1.649 & 1.610 \\
\hline Natrium Benzoat & 1,058 & 1.069 & 1.070 & 1.069 & $\mathrm{tt}$ & $\mathrm{tt}$ & $\mathrm{tt}$ & $\mathrm{tt}$ \\
\hline Kalium Sorbat & 1.122 & 1,046 & 1.042 & 1.042 & $\mathrm{tt}$ & $\mathrm{tt}$ & $\mathrm{tt}$ & $\mathrm{tt}$ \\
\hline
\end{tabular}

$\mathrm{tt}=$ tidak terdeteksi

Hasil penelitian optimasi panjang gelombang natrium sakarin, natrium siklamat, natrium benzoat, kalium sorbat, tartrazin dan sunset yellow diperoleh data faktor tailing memenuhi persyaratan yang diizinkan $(0,9<\mathrm{Ft}<2,0)$ dari panjang gelombang $200 \mathrm{~nm}-470 \mathrm{~nm}$ (Tabel 4.2).

Detektor DAD pada sistem KCKT yang digunakan hanya dapat mendeteksi natrium siklamat pada panjang gelombang $200 \mathrm{~nm}$ dengan faktor tailing 1,714 (Tabel 4.2) dan berada pada rentang y ang diizinkan, walaupun bukan pada panjang gelombang maksimum natrium siklamat $197 \mathrm{~nm}$ yang diperoleh dari spektrofotometer UV. Hal ini memberikan informasi bahwa natrium siklamat dapat dideteksi pada panjang gelombang $200 \mathrm{~nm}$ dengan menggunakan detektor DAD pada sistem KCKT. Pengembangan metode penetapan kadar siklamat dan implementasi paparan natrium siklamat pada manusia (Wibowotomo, 2008), 
validasi metode analisis penetapan kadar senyawa siklamat dalam minuman ringan (Novelina, dkk., 2009), juga menggunakan KCKT dengan panjang gelombang 200 nm. Dengan demikian, hasil penelitian sama dengan panjang gelombang yang digunakan oleh peneliti sebelumnya. Oleh karena itu, untuk penetapan kadar natrium siklamat dilakukan pada panjang gelombang $200 \mathrm{~nm}$.

Kromatogram serapan pelarut pada panjang gelombang $200 \mathrm{~nm}-220 \mathrm{~nm}$ dapat dilihat pada Gambar 4.4.
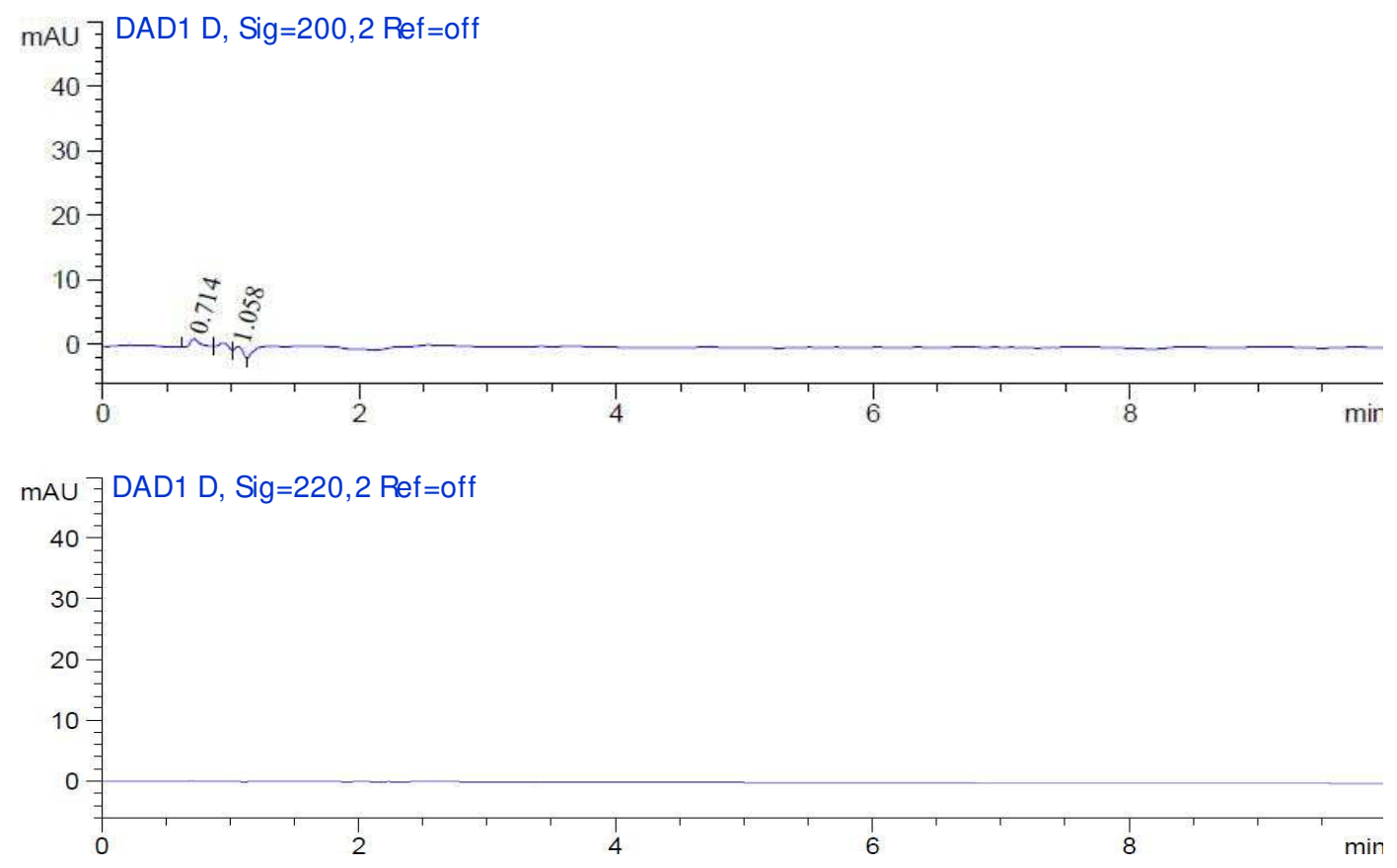

Gambar 4.4 Kromatogram Serapan Pelarut pada Panjang Gelombang 200 nm $220 \mathrm{~nm}$

Gambar 4.4 menunjukkan bahwa serapan pelarut buffer fosfat $\mathrm{pH}$ 4,5 dan metanol pada perbandingan $75: 25$ terjadi pada waktu retensi 0,714 menit $-1,058$ menit pada panjang gelombang $200 \mathrm{~nm}$, sehingga tartrazin dan natrium sakarin yang mempunyai waktu retensi masing-masing 0,941 menit dan 1,589 menit (Lampiran 13) tidak dapat dianalisis pada panjang gelombang $200 \mathrm{~nm}$, karena serapan pelarut akan mengganggu analisis tartrazin dan natrium sakarin. Gambar 
4.4 menunjukkan bahwa pada panjang gelombang $220 \mathrm{~nm}$ tidak terdapat serapan pelarut, maka analisis sakarin dapat dilakukan pada panjang gelombang $220 \mathrm{~nm}$.

Ree dan Stoa (2011), telah melakukan penetapan kadar sakarin, asam benzoat, aspartam dan kafein dalam minuman ringan dengan menggunakan KCKT detektor UV pada panjang gelombang tunngal $220 \mathrm{~nm}$. Sibarani (2010), telah menetapkan kadar natrium benzoat dan kalium sorbat dalam sirup dengan menggunakan KCKT detektor UV pada panjang gelombang $230 \mathrm{~nm}$. Matsunaga, et al. (1985), telah melakukan penetapan kadar sakarin, asam benzoat, asam sorbat dan lima ester asam- $p$-hidroksibenzoat dalam makanan dengan menggunakan KCKT detektor UV pada panjang gelombang $240 \mathrm{~nm}$. Hasil penelitian ini memberikan informasi bahwa penetapan kadar natrium sakarin, natrium benzoat dan kalium sorbat dapat dilakukan pada panjang gelombang $220-240 \mathrm{~nm}$. Faktor tailing dan tinggi serapan natrium sakarin, natrium benzoat dan kalium sorbat pada panjang gelombang $220 \mathrm{~nm}-240 \mathrm{~nm}$ dapat dilihat pada Gambar 4.5.
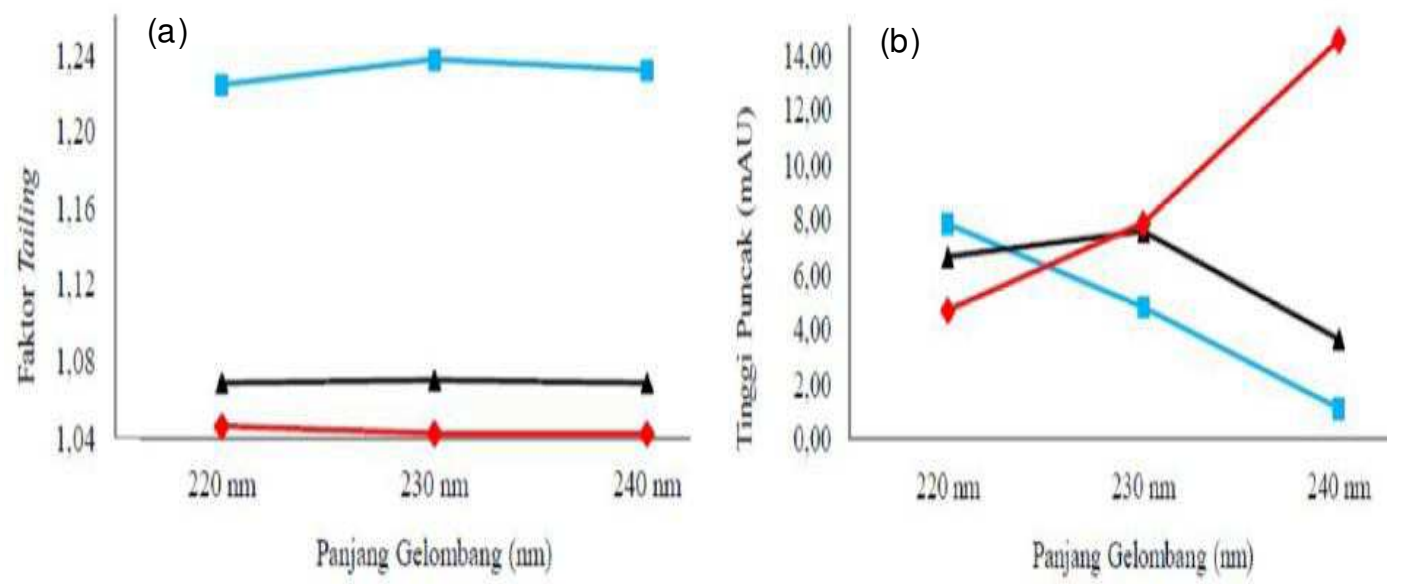

Gambar 4.5 Faktor Tailing (a) dan Tinggi Serapan (b) Natrium Sakarin (匹), Natrium Benzoat (A) dan Kalium Sorbat $(\diamond)$ pada Panjang Gelombang 220 nm - 240 nm 
Gambar 4.5 menunjukkan bahwa natrium sakarin lebih baik dianalisis pada panjang gelombang $220 \mathrm{~nm}$, karen a faktor tailing lebih kecil dan serapan natrium sakarin lebih tinggi. Oleh karena itu, penetapan kadar natrium sakarin, natrium benzoat dan kalium sorbat dilakukan pada panjang gelombang $220 \mathrm{~nm}$.

Kromatogram larutan baku ditambah sirup X pada panjang gelombang 220 nm - 240 nm dapat dilihat pada Gambar 4.6. Kromatogram larutan baku ditambah sirup X pada panjang gelombang $440 \mathrm{~nm}$ - $470 \mathrm{~nm}$ dapat dilihat pada Gambar 4.7.
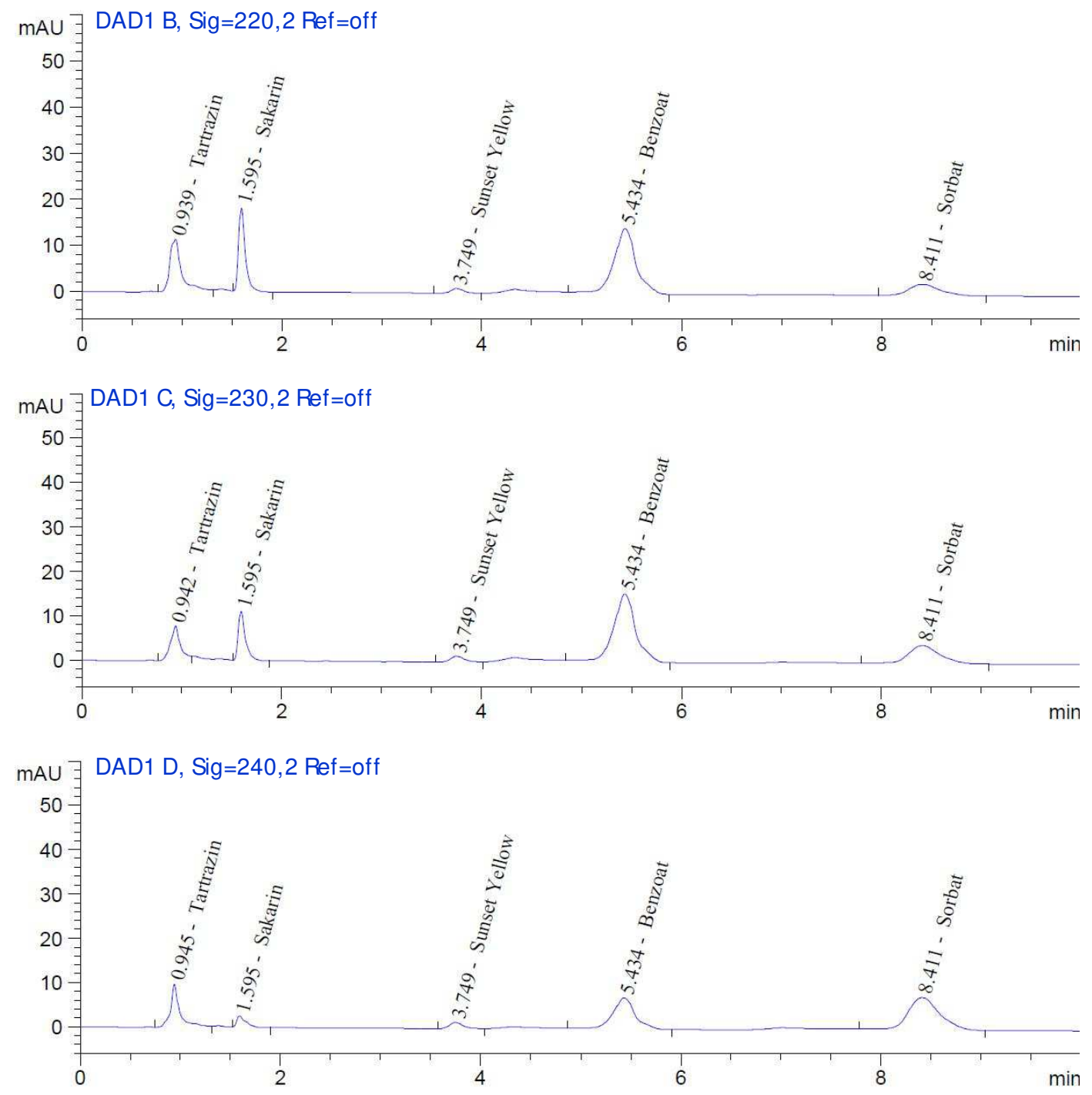

Gambar 4.6 Kromatogram Larutan Baku Ditambah Sirup X pada Panjang Gelombang $220 \mathrm{~nm}-240 \mathrm{~nm}$ 

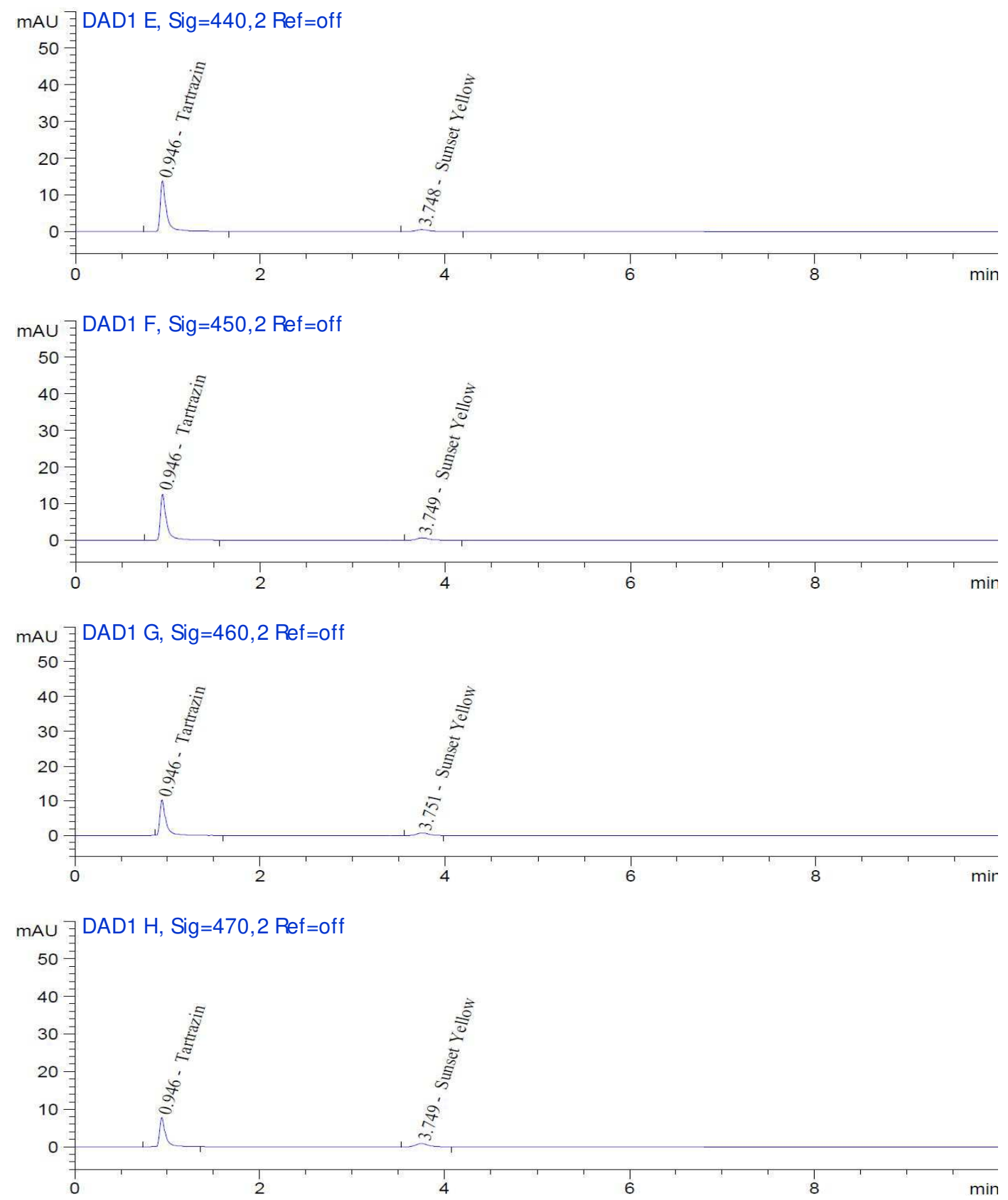

Gambar 4.7 Kromatogram Larutan Baku Ditambah Sirup X pada Panjang Gelombang $440 \mathrm{~nm}-470 \mathrm{~nm}$

Gambar 4.6 memberikan informasi bahwa serapan tartrazin kurang simetris, sedangkan Gambar 4.7 bentuk kromatogram tartrazin lebih simetris. Hal ini menunjukkan bahwa pada rentang panjang gelombang $220 \mathrm{~nm}-240 \mathrm{~nm}$ serapan tartrazin dipengaruhi oleh matriks sirup atau ada senyawa lain dalam komponen sirup yang tidak terelusi sempurna, sedangkan pada rentang panjang 
gelombang $440 \mathrm{~nm}$ - $470 \mathrm{~nm}$ serapan tartrazin tidak dipengaruhi oleh matriks sirup atau tidak ada senyawa lain dalam komponen sirup yang tidak terelusi sempurna, sehingga penetapan kadar tartrazin tidak dapat dilakukan pada panjang gelombang $220 \mathrm{~nm}-240 \mathrm{~nm}$.

Penetapan kadar tartrazin dan sunset yellow telah dilakukan dalam makanan ternak dengan menggunakan KCKT pada panjang gelombang $420 \mathrm{~nm}$ (Lee, at al., 2007). Penetapan kadar tartrazin dan sunset yellow dalam minuman beralkohol juga telah dilakukan dengan menggunakan KCKT pada panjang gelombang $450 \mathrm{~nm}$ (Prado, et al., 2006). Sedangkan Jurcovan, et al. (2012) menetapkan kadar tartrazin dan sunset yellow dalam minuman ringan dengan menggunakan KCKT pada panjang gelombang $470 \mathrm{~nm}$. Penelitian ini memberikan informasi bahwa penetapan kadar tartrazin dan sunset yellow dapat dilakukan pada panjang gelombang $420 \mathrm{~nm}-470 \mathrm{~nm}$. Faktor tailing dan tinggi serapan tartrazin maupun sunset yellow pada panjang gelombang $440 \mathrm{~nm}-470 \mathrm{~nm}$ dapat dilihat pada Gambar 4.8.
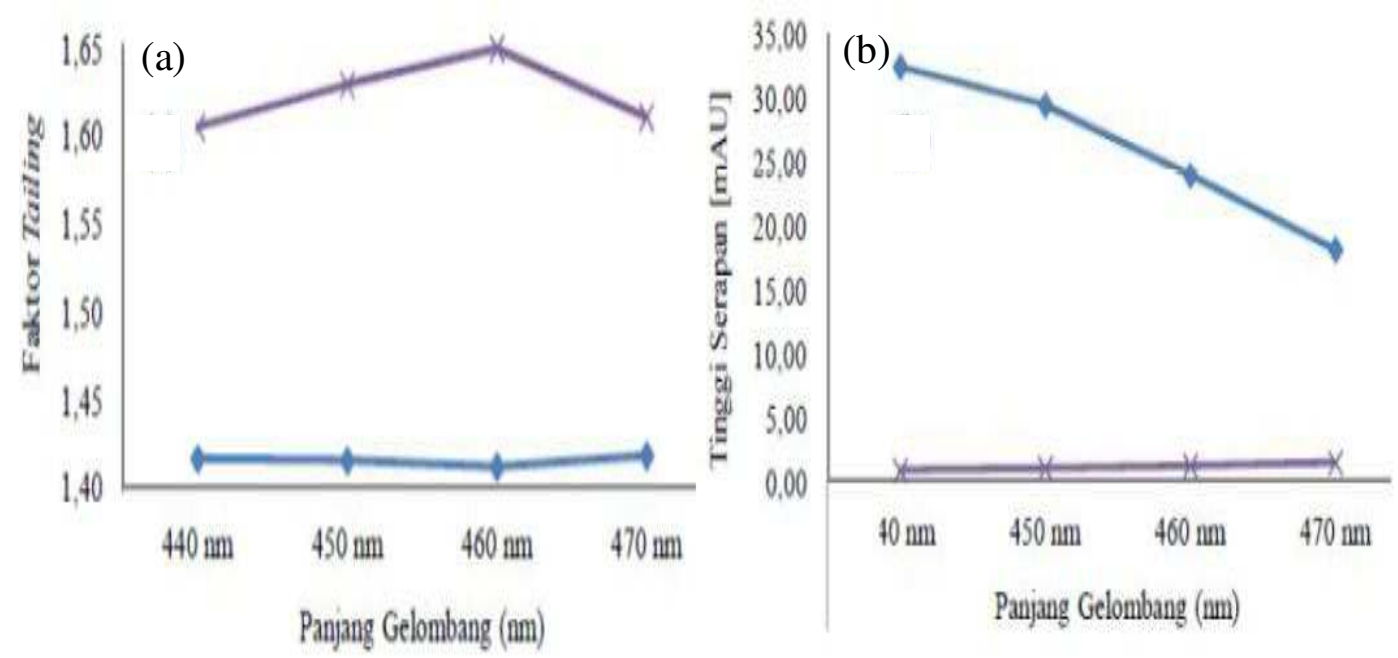

Gambar 4.8 Faktor Tailing (a) dan Tinggi Serapan (b) Tartrazin ( ) dan Sunset Yellow ( $\times$ ) pada Panjang Gelomb ang $440 \mathrm{~nm}-470 \mathrm{~nm}$ 
Gambar 4.8 menunnjukkan bahwa penetapan kadar tartrazin dan sunset yellow lebih baik dilakukan pada panjang gelombang $450 \mathrm{~nm}$. Walaupun faktor tailing sunset yellow sebesar 1,629 (Tabel 4.2) lebih tinggi dari panjang gelombang $440 \mathrm{~nm}(\mathrm{Ft}=1,604)$ dan $470 \mathrm{~nm}(\mathrm{Ft}=1,610)$. Hal ini dilakukan karena serapan sunset yellow dan tartrazin masing-masing pada panjang gelombang 440 $\mathrm{nm}$ dan $470 \mathrm{~nm}$ paling rend ah.

\subsubsection{Optimasi pH Fase Gerak}

Hasil optimasi $\mathrm{pH}$ fase gerak diperoleh data berupa waktu retensi, faktor kapasitas, jumlah plat teoritis, resolusi, selektifitas dan faktor tailing. Kromatogram optimasi $\mathrm{pH}$ larutan buffer fosfat dapat dilihat pada Lampiran 8, halaman 117 - 120. Pengaruh pH buffer terhadap parameter optimasi dapat dilihat pada Tabel 4.3.

Tabel 4.3 Pengaruh pH Buffer terhadap Parameter Optimasi

\begin{tabular}{|c|c|c|c|c|c|c|c|c|c|c|c|c|c|}
\hline \multirow{3}{*}{ Senyawa } & \multirow{3}{*}{\begin{tabular}{|c|}
$\begin{array}{c}\text { Panjang } \\
\text { Gelombang } \\
(\mathrm{nm})\end{array}$ \\
\end{tabular}} & \multicolumn{12}{|c|}{ pH Larutan Buffer Fosfat } \\
\hline & & \multicolumn{6}{|c|}{4,0} & \multicolumn{6}{|c|}{4,3} \\
\hline & & Rt & $\mathrm{k}^{\prime}$ & $\mathrm{N}$ & Rs & $\alpha$ & If & Rt & $\mathrm{k}^{\prime}$ & $\mathrm{N}$ & Rs & $a$ & If \\
\hline Tartra & 150 & 1,255 & 1,010 & 1701 & - & & 1,911 & 1,238 & 0,990 & 1132 & - & - & 1,127 \\
\hline Natril & & 2,010 & 2,230 & 4771 & 6,220 & 2,200 & 1,886 & 2,000 & 2,210 & 5014 & 5,570 & 2,240 & 01,89 \\
\hline Natriun & & 3,473 & 4,570 & 3107 & 8,020 & 2,050 & 2,357 & 3,454 & 4,540 & 2581 & 7,540 & 2,060 & 1,0 \\
\hline Sunset & 450 & 4,824 & 6,740 & 2606 & 14,280 & 6,650 & 1,784 & 4,738 & 6,600 & 3585 & 15,060 & 6,690 & 2,1 \\
\hline Natriu & & 1,367 & 17,240 & 4627 & 12,590 & 2,560 & 1,420 & 8,728 & 13,000 & 4585 & 9,610 & 1,970 & 01,0 \\
\hline Kalinn & 22( & 683 & 22,560 & 6364 & 4,710 & 1,310 & 1,839 & 12,653 & 19,300 & 5109 & 6,400 & 1,480 & 1,3 \\
\hline & & \multicolumn{6}{|c|}{4,5} & \multicolumn{6}{|c|}{4} \\
\hline Tarts & & 1 & 0,950 & 941 & - & - & 1,381 & 1,184 & 0,900 & 1196 & - & - & 1,0 \\
\hline Natriu & & 2,002 & 2,210 & 4986 & 5,750 & 2,330 & 1,976 & 1,980 & 2,180 & 5230 & 6,540 & 2,420 & 2,0 \\
\hline Natriun & & 3,470 & 4,570 & 3003 & 8,000 & 2,060 & 1,740 & 3,437 & 4,510 & 3332 & 8,370 & 2,070 & 0,8 \\
\hline Sunset Yellow & 450 & 4,747 & 6,620 & 3852 & 15,160 & 6,950 & 2,212 & 4,614 & 6,400 & 4736 & 16,900 & 7,110 & 2,1 \\
\hline Natrium Benzoat & & 7,366 & 10,820 & 3835 & 6,750 & 1,640 & 0,946 & 5,204 & 7,350 & 4160 & 1,980 & 1,150 & 01,0 \\
\hline Kalium Sorbat & 220 & 11,341 & 17,200 & 4848 & 7,040 & 1,590 & 1,072 & 8,612 & 12,820 & 4670 & 8,230 & 1,740 & 01,1 \\
\hline
\end{tabular}

Keterangan: - = Tak terdeteksi 
Fase gerak buffer asam menyebabkan senyawa basa terionisasi sehingga lebih cepat terelusi dan senyawa asam tidak terionisasi jika $\mathrm{pH}$ larutan buffer lebih kecil dari pKa senyawa asam tersebut sehingga lebih lambat terelusi atau sebaliknya. Larutan buffer yang dipilih harus memberikan pemisahan terbaik berdasarkan nilai resolusi dan faktor kapasitas, selain itu juga memberikan waktu analisis yang lebih singkat.

Hubungan $\mathrm{pH}$ dengan faktor tailing, resolusi dan faktor kapasitas natrium sakarin, natrium silkamat, natrium benzoat, kalium sorbat, tartrazin dan sunset yellow dapat dilihat pada Gambar 4.9.
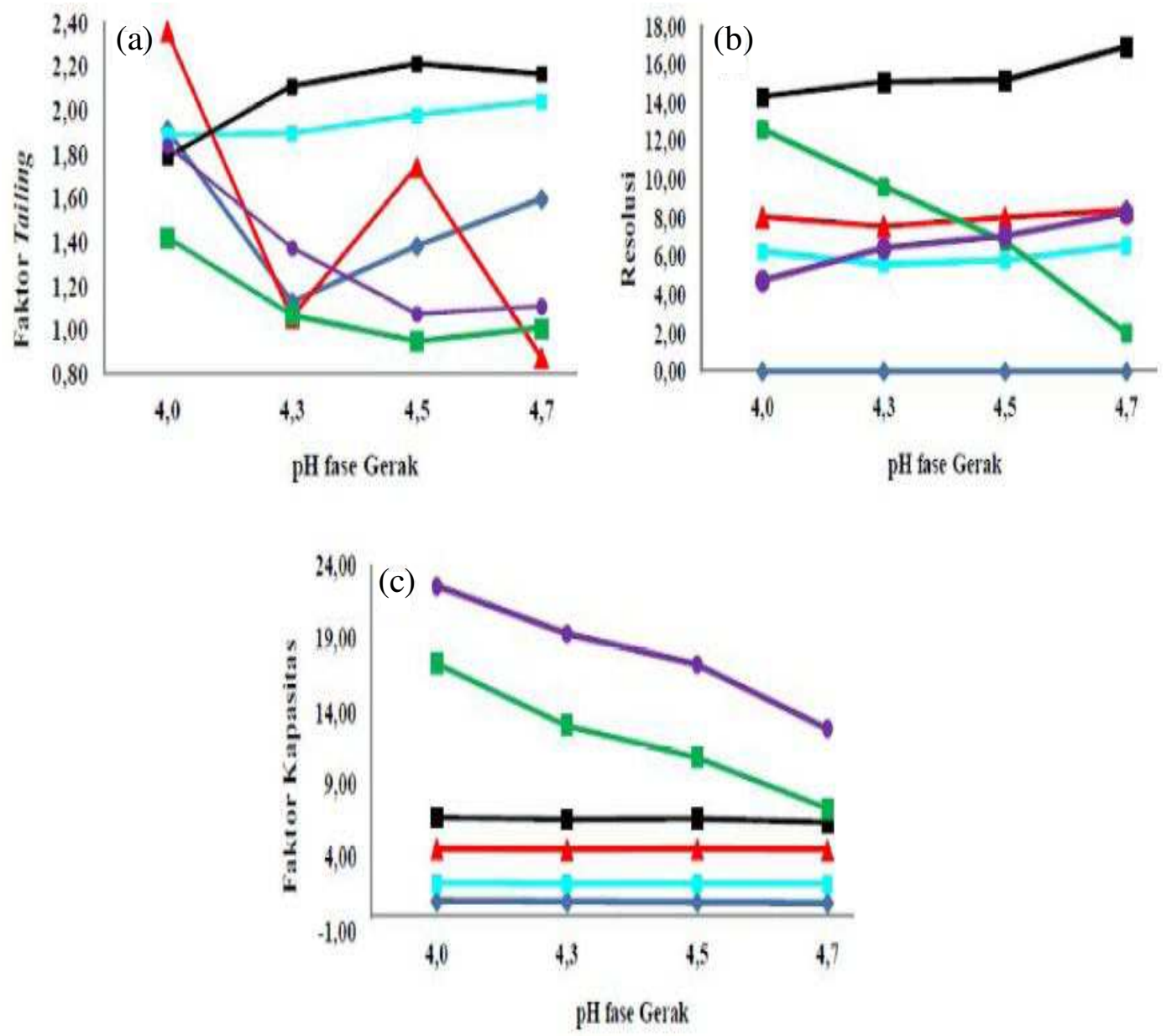

Gambar 4.9 Hubungan pH dengan Faktor Tailing (a), Resolusi (b) dan Faktor Kapasitas (c) Natrium Sakarin ( $\square$ ), Natrium Silkamat ( $\Delta$ ), Natrium Benzoat ( $\bullet$ ), Kalium Sorbat $(\bullet)$, Tartrazin $(\diamond)$ dan Sunset Yellow $(\bullet)$ 
Senyawa terpisah kurang baik pada fase gerak buffer fosfat $\mathrm{pH}$ 4,7 yang ditandai resolusi natrium benzoat sebesar 1,980 (Tabel 4.3) lebih kecil dari yang diizinkan untuk pengemban gan metode, y aitu Rs $\geq 2$ (Snyder, et al., 2010). Hal ini memberikan informasi bahwa ionisasi natrium benzoat $(\mathrm{pKa}=4,2)$ pada fase gerak buffer $\mathrm{pH}$ 4,7 menyebabkan waktu retensi menjadi lebih cepat dan resolusi menjadi buruk (Gamabr 4.9 dan Lampiran 10). Natrium sakarin dan sunset yellow men galami tailing dan natrium siklamat men galami fronting pada buffer fosfat $\mathrm{pH}$ 4,7 (Tabel 4.3, Gambar 4.9 dan Lampiran 10). Hal ini memberikan informasi bahwa ionisasi natrium sakarin $(\mathrm{pKa}=1,8)$, natrium siklamat $(\mathrm{pKa}=1,9)$ dan sunset yellow $(\mathrm{pKa}=9,2)$ meny ebabkan bentuk kromatogram natrium sakarin dan sunset yellow men galami tailing, sedan gk an natrium siklamat mengalami fronting.

Semua senyawa pada buffer fosfat $\mathrm{pH}$ 4,0 terpisah dengan baik, ditandai dengan resolusi $>2$, tetapi nilai faktor kapasitas kalium sorbat 22,560 (Tabel 4.3), berada di atas batas maksimal y ang diizinkan (Gambar 4.9). Nilai faktor kapasitas terlalu besar mengindikasikan bahwa waktu analisis menjadi lebih lama. Hal ini terjadi karena kalium sorbat $(\mathrm{pKa}=4,8)$ tidak mengalami ionisasi sehingga partisi dengan fase gerak kurang baik. Faktor tailing natrium siklamat $(\mathrm{pKa}=1,9)$ sebesar 2,357 (Tabel 4.3 dan Gambar 4.9). Hal ini memberikan informasi bahwa ionisasi natrium siklamat pada fase gerak buffer fosfat $\mathrm{pH}$ 4,0 meny ebabkan partisi dengan fase gerak kurang baik sehingga bentuk kromatogram menjadi tailing.

Seny awa terpisah dengan baik pada fase gerak buffer fosfat $\mathrm{pH} 4,3$ dan $\mathrm{pH}$ 4,5 karena memenuhi persyaratan parameter optimasi yang ditandai dengan resolusi $>2$, faktor kapasitas berada pada rentang persy aratan $(0,5 \leq \mathrm{k} \leq 20)$ dan selektivitas $>1$. Namun, sunset yellow $(\mathrm{pKa}=9,2)$ mengalami tailing baik pada fase gerak buffer fosfat $\mathrm{pH}$ 4,3 maupun $\mathrm{pH}$ 4,5 (Tabel 4.3 dan Gambar 4.9). Hal 
ini menunjukkan bahwa ionisasi sunset yellow pada fase gerak buffer fosfat $\mathrm{pH} 4,3$ dan $\mathrm{pH}$ 4,5 menyebabkan partisi sunset yellow pada fase gerak kurang baik sehingga bentuk kromatogram menjadi tailing. Tabel 4.3 menunjukkan bahwa faktor kapasitas kalium sorbat pada $\mathrm{pH} 4,3(\mathrm{k}=19,30)$ lebih besar dibandingkan pH 4,5 $(\mathrm{k}=17,20)$, sehingga analisis pada $\mathrm{pH} 4,3$ lebih lama dibandingkan pada pH 4,5. Oleh karena itu, larutan buffer fosfat yang dipilih untuk penelitian selanjutny a adalah buffer fosfat $\mathrm{pH} 4,5$.

Pylypiw dan Grether (2000), menggunakan fase gerak campuran asetonitril dan buffer amonium asetat $\mathrm{pH}$ 4,2 untuk penetapan kadar natrium benzoat dan kalium sorbat. Khosrokhavar, et al. (2010), menggunakan fase gerak campuran asetonitril dan buffer amonium asetat $\mathrm{pH}$ 4,4 untuk menetapan kadar natrium benzoat dan kalium sorbat. Xiao, et al. (2011), menggunakan fase gerak campuran asetonitril dan amonium sulfat $\mathrm{pH}$ 4,4 untuk menetapan kadar aspartam, natrium sakarin, natrium siklamat, kalium asesulfam, neotam dan steviosida. Shimadzu (2007), telah berhasil menetapkan kadar tartrazin dan sunset yellow dalam minunan dengan menggunakan fase gerak campuran asetonitril dan buffer amonium asetat $\mathrm{pH}$ 4,7. Hasil penelitian masing-masing peneliti tersebut diperoleh informasi bahwa pemisahan senyawa dalam campuran memenuhi syarat yang diizinkan.

Penelitian yang dilakukan dengan menggunakan fase gerak campuran metanol dan buffer fosfat $\mathrm{pH}$ 4,0 sampai $\mathrm{pH}$ 4,7 terny ata memberikan hasil yang terbaik pada fase gerak campuran metanol dan buffer fosfat $\mathrm{pH} 4,5$; berada pada rentang $\mathrm{pH}$ y ang dilakukan oleh peneliti sebelumnya. Perbedaan $\mathrm{pH}$ terjadi karena perbedaan fase gerak organik dan jenis buffer yang digunakan serta komponen seny awa y ang dip isahkan. 


\subsubsection{Optimasi Komposisi Fase Gerak}

Pengaruh komposisi fase gerak terhadap parameter optimasi dapat dilihat pada Tabel 4.4. Fase gerak yang dioptimasi adalah buffer fosfat $\mathrm{pH} 4,5$ dan metanol dengan perbandingan komposisi seperti pada Tabel 4.4. Kromatogram optimasi dapat dilihat pada Lampiran 9, halaman 121 - 123.

Tabel 4.4 Pengaruh Komposisi Fase Gerak terhadap Parameter Optimasi

\begin{tabular}{|c|c|c|c|c|c|c|c|c|c|c|c|c|c|c|c|c|c|c|c|}
\hline \multirow{3}{*}{ Senjawa } & \multirow{3}{*}{\begin{tabular}{|c} 
Pamiang \\
Gelombang \\
$(\mathrm{m})$
\end{tabular}} & \multicolumn{18}{|c|}{ Komposisis Fase Gerax Buffer - Metanol } \\
\hline & & \multicolumn{6}{|c|}{$77: 23$} & \multicolumn{6}{|c|}{$75: 25$} & \multicolumn{6}{|c|}{$73: 27$} \\
\hline & & Rt & 1 & $\mathrm{~N}$ & Rs & a & If & Rt & $k^{\prime}$ & $\mathrm{N}$ & Rs & a & If & Rt & k & $N$ & Rs & a & If \\
\hline Itraz & & 1.273 & 1,040 & 2826 & . & . & 2,493 & 1,239 & 0,990 & 1483 & & . & 1,430 & 1,169 & 0,880 & 1092 & 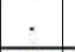 & & 1,559 \\
\hline & & 2,099 & 2,370 & 6725 & 8,340 & 2,270 & 1,192 & 1,948 & 2,130 & 6193 & 6,040 & 2,150 & 1,269 & 1,829 & 1,940 & 5757 & 5,650 & 2,210 & 1,311 \\
\hline Natriun & & 3,573 & 4,730 & 5486 & 9,980 & 2,000 & 1,740 & 3,292 & 4,280 & 4906 & 9,310 & 2,010 & 1,941 & 3,054 & 3,900 & 4900 & 9,010 & 2,020 & 2,10 \\
\hline tusset Yell & & 6,111 & 8,810 & 4193 & 20,400 & 8,440 & 1,611 & 4,724 & 6,580 & 3727 & 15,870 & 6,660 & 1,565 & 3,755 & 5,030 & 3547 & $13,130:$ & 5,740 & 1,649 \\
\hline & & 8,355 & 12,410 & 11931 & 6,510 & 1,410 & 1,045 & 7,431 & 10,920 & 11632 & 9,240 & 1,660 & 1,024 & 6,631 & 9,640 & 11072 & 11,280 & 1,920 & 1,020 \\
\hline limm Sorba & 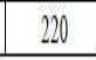 & 12,789 & 19,520 & 12238 & 11,660 & 1,570 & 1,048 & 11,188 & 16,950 & 12734 & 11,160 & 1,550 & 1,041 & 9,807 & 14,740 & 12474 & & 1,530 & 1,040 \\
\hline
\end{tabular}

Keterangan: - = Tak terdeteksi

Tabel 4.4 menunjukkan bahwa waktu retensi pada komposisi fase gerak buffer fosfat $\mathrm{pH} 4,5$ dan metanol $77: 23$ lebih lambat dibandingkan pada komposisi 75 : 25 dan 73 : 27. Komposisi metanol semakin meningkat menyebabkan faktor kapasitas, jumlah plat teoritis, resolusi dan selektivitas men galami penurunan, kecuali resolusi dan selektivitas natrium benzoat.

Faktor kapasitas natrium benzoat mengalami penurunan karena natrium benzoat $(\mathrm{pKa}=4,2)$ dalam fase gerak buffer fosfat $\mathrm{pH} 4,5$ belum terionisasi sempurna, sehingga peningkatan fraksi metanol menyebabkan kelarutan natrium benzoat bertambah. Resolusi dan selektivitas natrium benzoat meningkat menunjukkan bahwa pemisahan menjadi lebih sempurna. Sementara natrium sakarin, natrium siklamat, kalium sorbat, tartrazin dan sunset yellow mengalami penurunan resolusi dan selektivitas seiring peningkatan kelarutan natrium benzoat 
pada fase gerak dengan peningkatan fraksi metanol. Dengan demikian, faktor kapasitas mengalami penurunan disebabkan penurunan viskositas fase gerak, tidak disebabkan peningkatan kelarutan seny awa tersebut.

Pengaruh komposisi fase gerak terhadap faktor tailing natrium sakarin, natrium silkamat, natrium benzoat, kalium sorbat, tartrazin dan sunset yellow dapat dilihat pada Gambar 4.10.

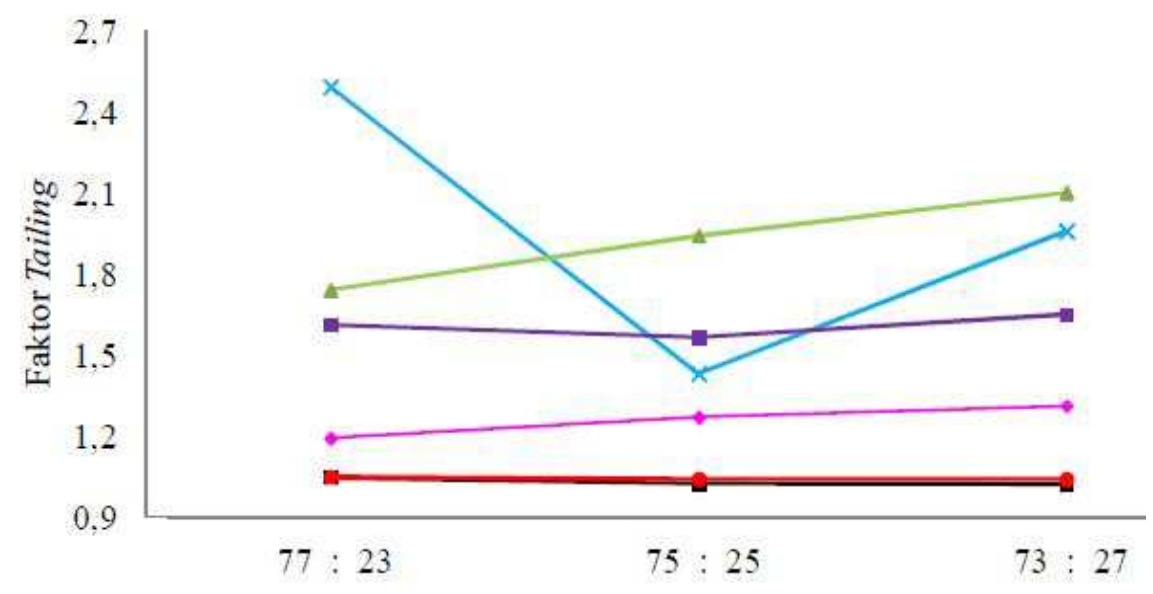

Komposisi Fase Gerak Buffer- Metanol

Gambar 4.10 Pengaruh Komposisi Fase Gerak terhadap Faktor Tailing Natrium Sakarin $(\diamond)$, Natrium Silkamat $(\triangle)$, Natrium Benzoat (₫), Kalium Sorbat $(\bullet)$, Tartrazin $(\times)$ dan Sunset Yellow $(\square)$

Hasil optimasi komposisi fase gerak memenuhi persyaratan parameter optimasi, kecuali natrium siklamat dan tartrazin mengalami tailing masing-masing pada fase gerak buffer fosfat $\mathrm{pH} 4,5$ dan metanol dengan perbandingan $73: 27$ dan 77 : 23 (Tabel 4.4 dan Gambar 4.10). Ionisasi dari natrium siklamat (pK = 1,9) dan tartrazin $(\mathrm{pKa}=10,9)$ menyebabkan natrium siklamat dan tartrazin tidak mampu berpartisi pada campuran fase gerak buffer fosfat dan metanol dengan perbandingan masing-masing $73: 27$ dan $77: 23$. Oleh karena itu, penelitian dilanjutkan dengan menggunakan komposisi buffer fosfat dan metanol dengan perbandingan $75: 25$. 


\subsubsection{Optimasi Laju Alir}

Laju alir yang dioptimasi adalah 0,$8 ; 1,0$ dan $1,2 \mathrm{ml} / \mathrm{menit}$. Pengaruh laju alir terhadap parameter optimasi dapat lihat pada Tabel 4.5 dan kromatogram optimasi laju alir dapat dilihat pada Lampiran 10, halaman 124 - 126.

Tabel 4.5 Pengaruh Laju Alir terhadap Parameter Optimasi

\begin{tabular}{|c|c|c|c|c|c|c|c|c|c|c|c|c|c|c|c|c|c|c|c|}
\hline \multirow{3}{*}{ Senzama } & \multirow{3}{*}{$\begin{array}{c}\text { Panjang } \\
\text { Gelombang } \\
(\mathrm{mm})\end{array}$} & \multicolumn{18}{|c|}{ LajuAlir (mlmentit) } \\
\hline & & \multicolumn{6}{|c|}{$0,8(120$ bar $)$} & \multicolumn{6}{|c|}{$1,0(133 \mathrm{bar})$} & \multicolumn{6}{|c|}{$1.2(156$ bar $)$} \\
\hline & & $R t$ & $k$ & N & Rs & $a$ & If & Rt & $\mathrm{K}^{\prime}$ & $N$ & Rs & $a$ & If & Rt & $k$ & N & Rs & $a$ & If \\
\hline atrazin & 450 & 1,242 & 0,990 & 1710 & $\cdot$ & . & 1,406 & 0.991 & 0,990 & 1309 & . &. & 1,336 & 0,822 & 0,980 & 1061 & . & . & 1,337 \\
\hline Natrum Salarin & 220 & 1,950 & 2,130 & 6276 & 6,340 & 140 & 1,316 & 1,559 & 2,130 & 4943 & 5.570 & 2,150 & 1,181 & 1,297 & 2,120 & 3688 & 4,960 & 2,170 & 1,067 \\
\hline Natrum Sitchamat & 200 & 3,294 & 4,280 & 4906 & 9,340 & 010 & 2,235 & 2,632 & 4,280 & 4628 & 8,780 & 2,010 & 1,926 & 2,191 & 4,270 & 4164 & 8,060 & 2,010 & 1,450 \\
\hline Sinset Yellow & 450 & 4,723 & 6,580 & 3835 & 16,360 & 6,630 & 1.581 & 3,776 & 6,570 & 3429 & 15,130 & 6,650 & 1,600 & 3,144 & 6,570 & 3246 & 14,420 & 6,710 & 1,471 \\
\hline Natraum Benzoat & 12 & 7,430 & 10,920 & 11936 & 9,470 & 660 & 1,052 & 5,918 & 10,870 & 10921 & 8,830 & 1,650 & 1,011 & 4,910 & 10,820 & 9912 & 8,380 & 1,650 & 1,043 \\
\hline Kalum Sorlat & 220 & 11,182 & 16,940 & 13455 & 11,400 & 1.550 & 1,042 & 8,897 & 16,850 & 12299 & 10,870 & 1,550 & 1,016 & 7,383 & 16,770 & 11786 & 10,530 & 1,550 & 1,040 \\
\hline
\end{tabular}

Keterangan: - = Tak terdeteksi

Pengaruh laju alir terhadap parameter optimasi (Tabel 4.5) menunjukkan bahwa peningkatan laju alir menyebabkan waktu retensi, jumlah plat teoritis, resolusi dan faktor tailing semakin menurun, kecuali faktor tailing natrium benzoat dan kalium sorbat. Hal ini memberikan infornasi bahwa peningkatan laju alir mempercepat waktu analisis, memperburuk efektivitas kolom sehingga pemisahan menjadi tidak sempuran, namun memperbaiki faktor tailing untuk senyawa basa lemah dan asam lemah yang larut dan terionisasi sempurna. Natrium benzoat $(\mathrm{pKa}=4,2)$ y ang men galami ionisasi tidak sempurna dan kalium sorbat $(\mathrm{pKa}=4,8)$ y ang tidak terionisasi pada fase gerak campuran buffer fosfat pH 4,5 dan metanol dengan perbandingan 75 : 25 maka faktor tailing tidak dip engaruhi oleh laju alir. 
Pengaruh laju alir terhadap tekanan pompa sistem KCKT dan faktor tailing natrium sakarin, natrium silkamat, natrium benzoat, kalium sorbat, tartrazin dan sunset yellow dapat dilihat pada Gambar 4.11.
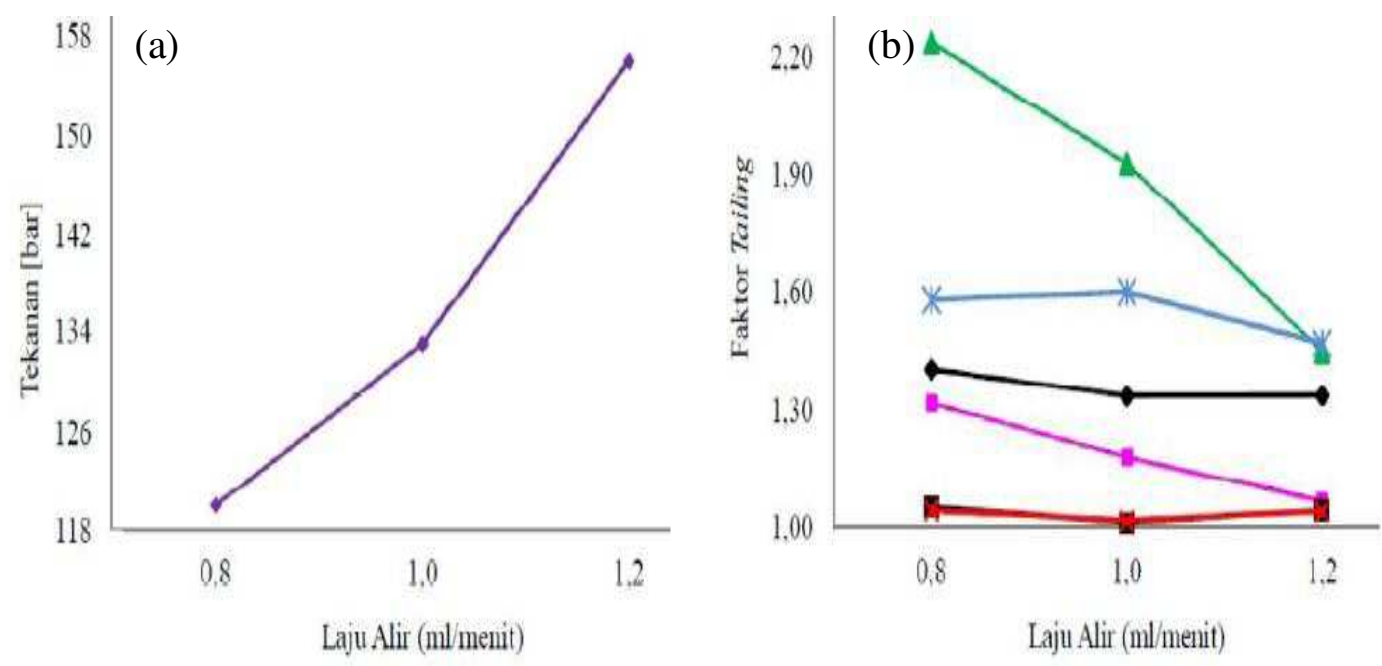

Gambar 4.11 Pengaruh Laju Alir terhadap Tekanan Pompa Sistem KCKT (a) dan Faktor Tailing (b) Natrium Sakarin ( $\square)$, Natrium Silkamat ( $\Delta$ ), Natrium Benzoat (•), Kalium Sorbat $(\times)$, Tartrazin $(\bullet)$ dan Sunset Yellow $(*)$

Nilai faktor tailing natrium siklamat sebesar 2,235 pada laju alir 0,8 $\mathrm{ml} / \mathrm{menit}$ dan mengalami penurunan yang sangat signifikan dengan peningkatan laju alir, sehingga pada laju alir 1,2 ml/menit menjadi 1,450 (Tabel 4.5 dan Gambar 4.11). Hal ini memberikan indikasi bahwa laju alir dapat memperbaiki bentuk kromatogram senyawa yang mengalami tailing. Penurunan faktor tailing tersebut bukan disebabkan peningkatan kelarutan natrium siklamat pada fase gerak, tetapi disebabkan peningkatan tekanan pompa sistem KCKT (Gambar 4.11). Jumlah plat teoritis tartrazin pada laju alir 1,0 ml/menit sebesar 1309 (Tabel 4.5) lebih besar dari laju alir $1,2 \mathrm{ml} /$ menit $(\mathrm{N}=1061)$, sehingga penelitian dilanjutkan dengan menggunakan laju alir 1,0 ml/menit. 


\subsubsection{Optimasi Suhu Kolom}

Suhu kolom yang dioptimasi adalah $25^{\circ} \mathrm{C}, 30^{\circ} \mathrm{C}$ dan $35^{\circ} \mathrm{C}$. Hasil optimasi suhu kolom diperoleh data berupa waktu retensi, faktor kapasitas, jumlah plat teoritis, resolusi, selektifitas dan faktor tailing. Pengaruh suhu kolom terhadap parameter optimasi dapat lihat pada Tabel 4.6 dan kromatogram optimasi suhu kolom dapat dilihat pada Lampiran 11, halaman 127 - 129.

Tabel 4.6 Pengaruh Suhu Kolom terhadap Parameter Optimasi

\begin{tabular}{|c|c|c|c|c|c|c|c|c|c|c|c|c|c|c|c|c|c|c|c|}
\hline \multirow{3}{*}{ Sermaxa } & \multirow{3}{*}{$\begin{array}{c}\text { Paring } \\
\text { Cetombang } \\
(\mathrm{min})\end{array}$} & \multicolumn{18}{|c|}{ Suluu Kolom( (C) } \\
\hline & & \multicolumn{6}{|c|}{25} & \multicolumn{6}{|c|}{30} & \multicolumn{6}{|c|}{35} \\
\hline & & $R t$ & $k$ & $N$ & Rs & $a$ & If & Rt & k' & $\mathrm{N}$ & Rs & $a$ & If & Rt & $k^{\prime}$ & N & Rs & $a$ & Tf \\
\hline Tatrazin & 450 & 1,021 & 1,050 & 2163 & . & . & 2282 & 0,093 & 0,990 & 1330 & . & $\cdot$ & 1,306 & 0,928 & 0,860 & 1151 & . & . & 1,723 \\
\hline Natrium Salarin & 220 & 1,045 & 2300 & 2300 & 6090 & 2,190 & 1.167 & 1,561 & 2,130 & 5023 & 5,630 & 2,150 & 1.233 & 1,489 & 1990 & 4745 & 5,800 & 2310 & 1.277 \\
\hline Natrinum Siklamat & 200 & 2,736 & 4,490 & 490 & 8,750 & 1,950 & 1,721 & 2,635 & 4,280 & 4207 & 8,510 & 2010 & 1,615 & 2,535 & 4,080 & 4082 & 8,430 & 2,060 & 0.881 \\
\hline Simset Yellow & 450 & 4,644 & 8,310 & 3343 & 17,700 & 7,440 & 1,009 & 3,790 & 6,600 & 3713 & 15,520 & 6,660 & 1,555 & 3,150 & 5320 & 3942 & 14,320 & 6,170 & 1,487 \\
\hline Aatrium Berizoat & 220 & 6,600 & 12,360 & 11031 & 7,010 & 1,490 & 1,021 & 50955 & 10,900 & 11150 & 9,060 & 1.650 & 1,029 & 5318 & 9,70 & 111188 & 10.770 & 1,820 & 1,006 \\
\hline Kaliom Sorbat & 220 & 9,912 & 18,880 & 12366 & 10,640 & 1,530 & 1,030 & 8,918 & 16,890 & 12957 & 11,090 & 1.550 & 1,017 & 8,050 & 15,150 & 12914 & 10,770 & 1,570 & 1,044 \\
\hline
\end{tabular}

Hasil optimasi suhu kolom memberikan informasi bahwa suhu kolom sangat signifikan mempengaruhi waktu retensi dan faktor kapasitas (Tabel 4.6). Hal ini memberikan gambaran bahwa suhu kolom dinaikkan maka viskositas fase gerak mengalami penurunan, sehingga faktor kapasitas semakin kecil dan waktu retensi semakin cepat. Kenaikan suhu masih memberikan pemisahan senyawa dengan baik karena proses elusi pemisahan senyawa pada sistem KCKT yang dipilih berlangsung dengan baik dan masih memenuhi persyaratan, kecuali nilai faktor tailing tartrazin 2,282 pada suhu kolom $25^{\circ} \mathrm{C}$ dan natrium siklamat 0,881 pada suhu kolom $35^{\circ} \mathrm{C}$. Oleh karena itu, penelitian selanjutnya dilakukan pada suhu kolom $30^{\circ} \mathrm{C}$. 


\subsection{Hasil Optimasi}

Hasil optimasi kondisi sistem KCKT adalah fase gerak buffer fosfat $\mathrm{pH}$ 4,5 : metanol (75:25), suhu kolom $30{ }^{\circ} \mathrm{C}$ dan laju alir $1,0 \mathrm{ml} / \mathrm{menit}$ dengan panjang gelombang deteksi $200 \mathrm{~nm}$ untuk siklamat, $220 \mathrm{~nm}$ untuk sakarin, benzoat dan sorbat serta $450 \mathrm{~nm}$ untuk tartrazin dan sunset yellow yang masingmasing dapat dilihat pada Gambar 4.12, Gambar 4.13 dan Gambar 4.14.

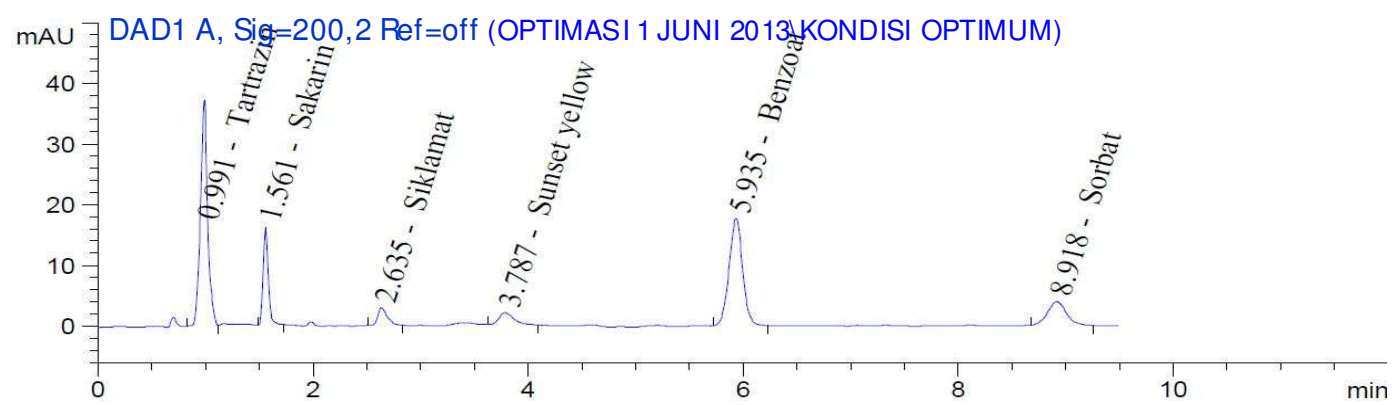

Gambar 4.12 Kromatogram Senyawa Hasil Optimasi Metode pada Panjang Gelombang $200 \mathrm{~nm}$

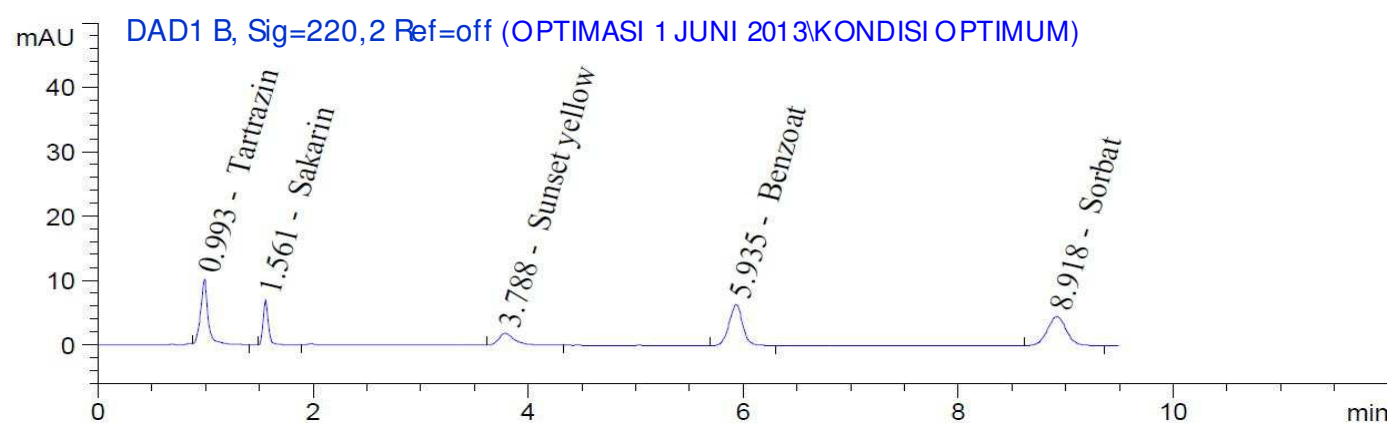

Gambar 4.13 Kromatogram Senyawa Hasil Optimasi Metode pada Panjang Gelombang $220 \mathrm{~nm}$

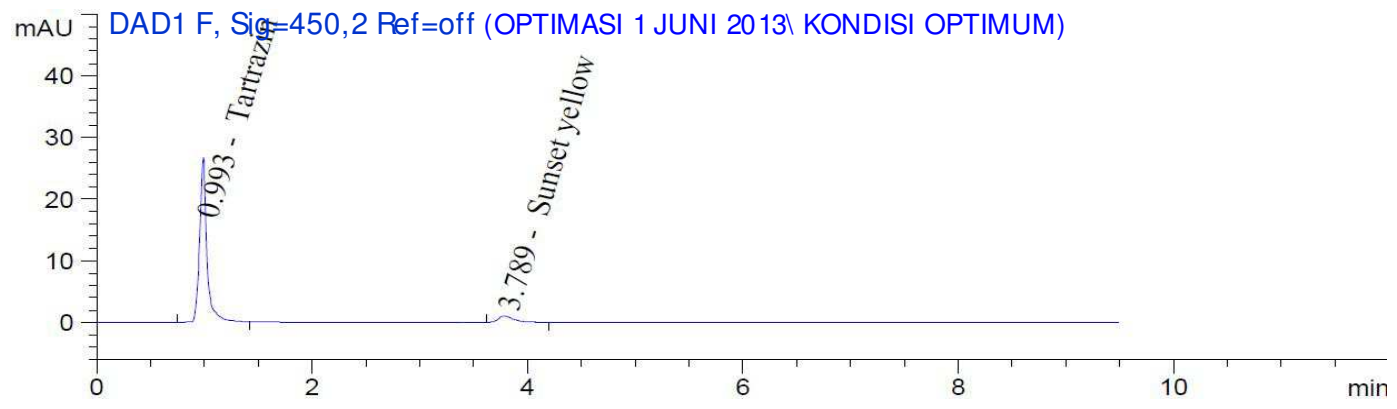

Gambar 4.14 Kromatogram Senyawa Hasil Optimasi Metode pada Panjang Gelombang $450 \mathrm{~nm}$ 


\subsection{Waktu Retensi}

Hasil penentuan waktu retensi menunjukkan bahwa natrium sakarin, natrium siklamat, natrium benzoat, kalium sorbat, tartrazin dan sunset yellow memiliki waktu retensi berbeda-beda yang dapat digunakan sebagai identifikasi masing-masing seny awa untuk analisis selanjutnya. Waktu retensi masing-masing senyawa adalah tartrazin 0,941 menit; natrium sakarin 1,589 menit; natrium siklamat 2,748 menit; sunset yellow 3,703 menit; natrium benzoat 5,516 dan kalium sorbat 8,583 menit. Kromatogram waktu retensi masing-masing senyawa baku dapat dilihat pada Lampiran 12, halaman 130 - 131, sedangkan waktu retensi masing-masing seny awa baku dapat dilihat pada Lampiran 13, halaman 132.

Pada sistem KCKT fase terbalik, fase diam bersifat non polar dan fase gerak bersifat polar. Waktu retensi memberikan gambaran kepolaran masing-masing senyawa, kepolaran tertinggi dimiliki oleh tartrazin karena terelusi terlebih dahulu, berikutnya adalah natrium sakarin, dilanjutkan oleh natrium siklamat, sunset yellow, natrium benzoat dan diakhiri oleh kalium sorbat berdasarkan waktu retensi masing-masing, yaitu: 1,589 menit; 2,748 menit; 3,703 menit; 5,516 dan 8,583 menit. 


\subsection{Validasi Metode}

\subsubsection{Linienitas Baku}

Kurva linearitas natrium sakarin, natrium siklamat, natrium benzoat, kalium sorbat, tartrazin dan sunset yellow dapat dilihat pada Gambar 4.15. Kromatogram overlay larutan baku seri dapat dilihat pada Lampiran 14 halaman 133 - 135, sedangkan massa, konsentrasi larutan baku dan hubungan konsentrasi dengan luas area larutan baku seri dapat dilihat pada Lampiran 15, halaman 136.

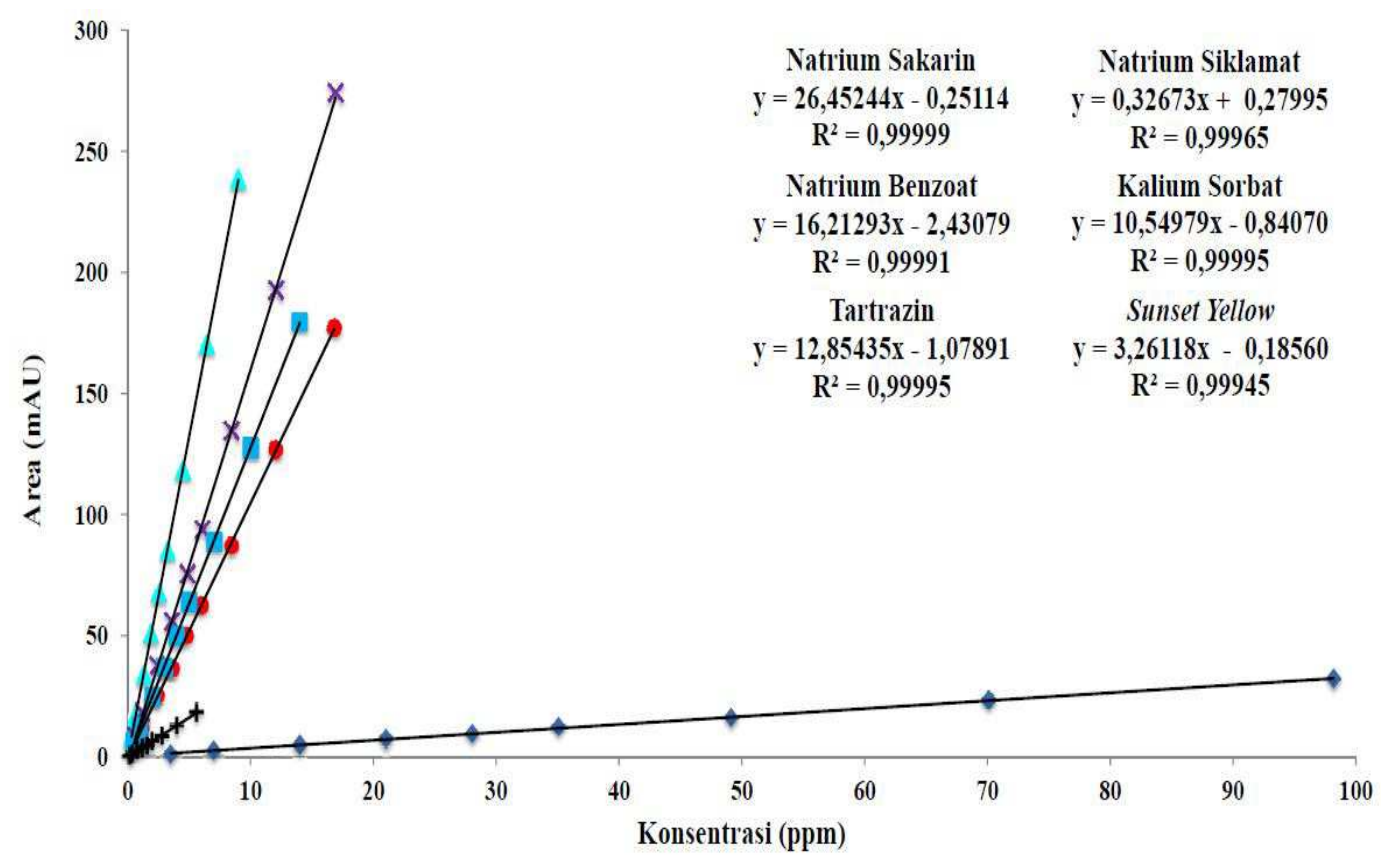

Gambar 4.15 Kurva Linearitas Natrium Sakarin ( $\triangle$ ), Natrium Silkamat $(\diamond)$, Natrium Benzoat $(\times)$, Kalium Sorbat $(\bullet)$, Tartrazin $(\square)$ dan Sunset Yellow (+)

Linearitas baku dilakukan terhadap sembilan larutan baku seri menunjukkan gar is regresi y ang baik, karena koefisien korelasi dari keenam senyawa mendekati nilai satu, berada pada kisaran 0,99945 - 0,99999. Hasil menunjukkan adanya korelasi yang baik antara konsentrasi senyawa dengan luas area y ang dihasilkan dari sistem KCKT hasil optimasi. Nilai koefisien korelasi (r) merupakan indikator kualitas dari parameter linearitas yang menggambarkan proporsionalitas respon seny awa (luas area) terhadap konsentrasi y ang diukur (Novelina, dkk., 2009). 


\subsubsection{Batas Deteksi dan Batas Kuantitasi}

Batas deteksi dan kuantitasi dihitung secara statistik melalui garis regresi linear dari kurva kalibrasi. Nilai kepekaan pengukuran akan sama dengan nilai b (slope) pada persamaan garis linear, sedangkan simpangan baku residual ( $\mathrm{Sy} / \mathrm{x})$ menunjukkan simpangan baku blanko (Harmita, 2004). Batas deteksi dan batas kuantitasi masing-masing seny awa dapat dilihat pada Tabel 4.7. Perhitungan batas deteksi dan batas kuantitasi dapat dilihat pada Lampiran 16, halaman 137 - 140.

Tabel 4.7 Batas Deteksi dan Batas Kuantitasi Masing-Masing Senyawa

\begin{tabular}{|c|l|c|c|}
\hline No & \multicolumn{1}{|c|}{ Senyawa } & Batas Deteksi $(\mathrm{ppm})$ & Batas Kuantitasi $(\mathrm{ppm})$ \\
\hline 1 & Natrium Sakarin & 0,03634 & 0,12113 \\
\hline 2 & Kalium Sorbat & 0,16542 & 0,55141 \\
\hline 3 & Tartrazin & 0,14939 & 0,49795 \\
\hline 4 & Sunset Yellow & 0,19097 & 0,63655 \\
\hline 5 & Natrium Benzoat & 0,23882 & 0,79608 \\
\hline 6 & Natrium Siklamat & 2,66306 & 8,87687 \\
\hline
\end{tabular}

Joseph (2012), menggunakan KCKT 1290 Infinity dengan diode array detector (Agilent), diperoleh batas deteksi dalam kisaran konsentrasi 0,05 ppm sampai 0,25 ppm pada penetapan dari sepuluh pewarna dalam manisan, termasuk kadar tartrazin dan sunset yellow. Alat y ang digunakan untuk penelitian sama dan hasil yang diperoleh untuk tartrazin dan sunset yellow berada pada rentang yang dilakukan oleh Joseph (2012). Dengan demikian, dapat diny atakan bahwa metode KCKT yang digunakan memberikan hasil yang cukup sensitif karena mampu mendeteksi senyawa dalam kisaran konsentrasi 0,03634 ppm (natrium sakarin) 2,66306 ppm (natrium siklamat). 


\subsubsection{Akurasi}

Persentase perolehan kembali masing-masing senyawa dapat dilihat pada Tabel 4.8. Kromatogram akurasi dapat dilihat pada Lampiran 17, halaman 141 152. Luas area masing-masing senyawa dalam larutan sirup $X$ dan sirup $X$ ditambah baku dapat dilihat pada Lampiran 18, halaman 153. Contoh perhitungan konsentrasi senyawa dalam sirup $\mathrm{X}$ ditambah baku pada Lampiran 19, halaman 154. Contoh perhitungan konsentrasi senyawa dalam sirup $X$ dapat dilihat pada Lampiran 20, halaman 155. Contoh perhitungan konsentrasi sebenarnya yang ditambahkan dalam sirup $\mathrm{X}$ dan persen perolehan dapat dilihat pada Lampiran 21, halaman 156. Konsentrasi sebenarnya yang ditambahkan dalam sirup X, konsentrasi senyawa dalam sirup $\mathrm{X}$ ditambah baku dan sirup $\mathrm{X}$ serta persen perolehan kembali dapat dilihat Lampiran 22, halaman 157.

Tabel 4.8 Persen Perolehan Kembali Masing-Masing Senyawa

\begin{tabular}{|c|c|c|c|c|c|c|c|}
\hline \multirow{2}{*}{ No. } & \multirow{2}{*}{$\begin{array}{c}\text { Perlakuan } \\
\text { Akurasi }\end{array}$} & Tartrazin & $\begin{array}{c}\text { Kalium } \\
\text { Sorbat }\end{array}$ & $\begin{array}{c}\text { Sunset } \\
\text { Yellow }\end{array}$ & $\begin{array}{c}\text { Natrium } \\
\text { Benzoat }\end{array}$ & $\begin{array}{c}\text { Natrium } \\
\text { Siklamat }\end{array}$ & $\begin{array}{c}\text { Natrium } \\
\text { Sakarin }\end{array}$ \\
\cline { 3 - 8 } & Akurasi $80 \%$ & $91,20 \%$ & $94,71 \%$ & $101,67 \%$ & $99,98 \%$ & $108,98 \%$ & $103,99 \%$ \\
\hline 2 & Akurasi $100 \%$ & $92,46 \%$ & $101,05 \%$ & $97,69 \%$ & $99,49 \%$ & $101,70 \%$ & $105,78 \%$ \\
\hline 3 & Akurasi $120 \%$ & $95,08 \%$ & $102,53 \%$ & $105,40 \%$ & $106,00 \%$ & $100,09 \%$ & $107,38 \%$ \\
\hline & Rata-rata & $92,92 \%$ & $99,43 \%$ & $101,59 \%$ & $101,82 \%$ & $103,59 \%$ & $105,72 \%$ \\
\hline
\end{tabular}

Tabel 4.8 memberikan informasi bahwa kisaran nilai rata-rata persen perolehan kembali adalah 92,92\% - 105,72\%. Nilai ini masih memenuhi persyaratan untuk kategori kadar senyawa 0,1\%; yaitu dengan rentang 90\% 108\% (Farrar dan White, 2012). Mayoritas persen perolehan kembali dari penelitian di atas 98\%, seperti yang dilakukan oleh peneliti Joseph (2012). Dengan demikian, metode pengujian yang digunakan dapat dinyatakan memiliki tingkat akurasi yang baik, karena berada pada rentang yang diizinkan dan relatif sama den gan peneliti sebelumnya. 


\subsubsection{Presisi}

Uji presisi atau keseksamaan merupakan ukuran yang menunjukkan derajat kesesuaian antara hasil uji individual jika prosedur diterapkan secara berulang pada sampel yang diambil dari campuran yang homogen (uji ripitabilitas) atau dikerjakan pada kondisi, tempat, peralatan, pereaksi, pelarut atau analis y ang berbeda dengan sampel diduga identik (uji reproduksibilitas). Dalam penelitian dilakukan uji presisi meliputi uji ripitabilitas (URI) dan uji reproduksibilitas (URE). Presisi ripitabilitas dan reproduksibilitas metode dapat dilihat pada Tabel 4.9. Kromatogram presisi dapat dilihat pada Lampiran 23, halaman 158 - 169. Contoh perhitungan standar deviasi dan persentase relative standard deviation dapat dilihat pada Lampiran 24, halaman 170. Luas area dan hasil perhitungan presisi dapat dilihat pada Lampiran 25, halaman 171.

Tabel 4.9 Presisi Ripitabilitas dan Reproduksibilitas Metode

\begin{tabular}{|c|c|c|c|c|c|c|c|}
\hline \multirow{2}{*}{ No } & \multirow{2}{*}{$\begin{array}{c}\text { Jenis } \\
\text { Presisi }\end{array}$} & \multicolumn{6}{|c|}{ Relative Standard Deviation (\%) } \\
\cline { 3 - 8 } & $\begin{array}{c}\text { Natrium } \\
\text { Sakarin }\end{array}$ & $\begin{array}{c}\text { Natrium } \\
\text { Siklamat }\end{array}$ & $\begin{array}{c}\text { Natrium } \\
\text { Benzoat }\end{array}$ & $\begin{array}{c}\text { Kalium } \\
\text { Sorbat }\end{array}$ & Tartrazin & $\begin{array}{c}\text { Sunset } \\
\text { Yellow }\end{array}$ \\
\hline 1 & URI & 0,50 & 1,53 & 0,30 & 0,38 & 0,11 & 0,96 \\
\hline 2 & URE & 0,07 & 1,94 & 0,04 & 0,20 & 0,68 & 1,30 \\
\hline
\end{tabular}

Uji presisi menunjukkan bahwa sistem KCKT yang digunakan memberikan hasil uji keterulangan metode atau uji ripitabilitas (URI) dan uji ketertiruan metode atau uji reproduksibilitas (URE) memenuhi persyaratan dengan persentase relative standard deviation masing-masing lebih kecil dari $3 \%$ dan $6 \%$, untuk kategori kadar senyawa dalam sampel 0,1\% (Farrar dan White, 2012). Kailasam (2010), memperoleh presisi metode dengan persentase relative standard deviation dari luas area sakarin, asam benzoat dan asam sorbat masingmasing sebesar 0,16; 0,30 dan 0,40 pada analisis ultrafast dan sensitif dari pemanis, pengawet dan flavor dalam minuman non alkohol dengan menggunakan Agilent 1290 Infinity LC system. Sistem operasi alat, metode dan analis memiliki 
nilai presisi yang baik karena respon relatif konstan sehingga hasil pengukuran memiliki nilai presisi memenuhi syarat dan relatif sama dengan peneliti sebelumnya.

\subsubsection{Selektifitas}

Uji selektivitas dilakukan dengan membandingkan kromatogram larutan baku, larutan sirup X dan larutan sirup X ditambah baku. Kromatogram overlay larutan baku, larutan sirup $\mathrm{X}$ dan larutan sirup $\mathrm{X}$ ditambah baku pada panjang gelombang $200 \mathrm{~nm}$ dapat dilih at pada Gambar 4.16. Kromatogram overlay larutan baku, larutan sirup $\mathrm{X}$ dan larutan sirup $\mathrm{X}$ ditambah baku pada panjang gelombang $220 \mathrm{~nm}$ dapat dilihat pada Gambar 4.17. Kromatogram overlay larutan baku, larutan sirup $X$ dan larutan sirup $X$ ditambah baku pada panjang gelombang 450 nm dapat dilihat pada Gambar 4.18.

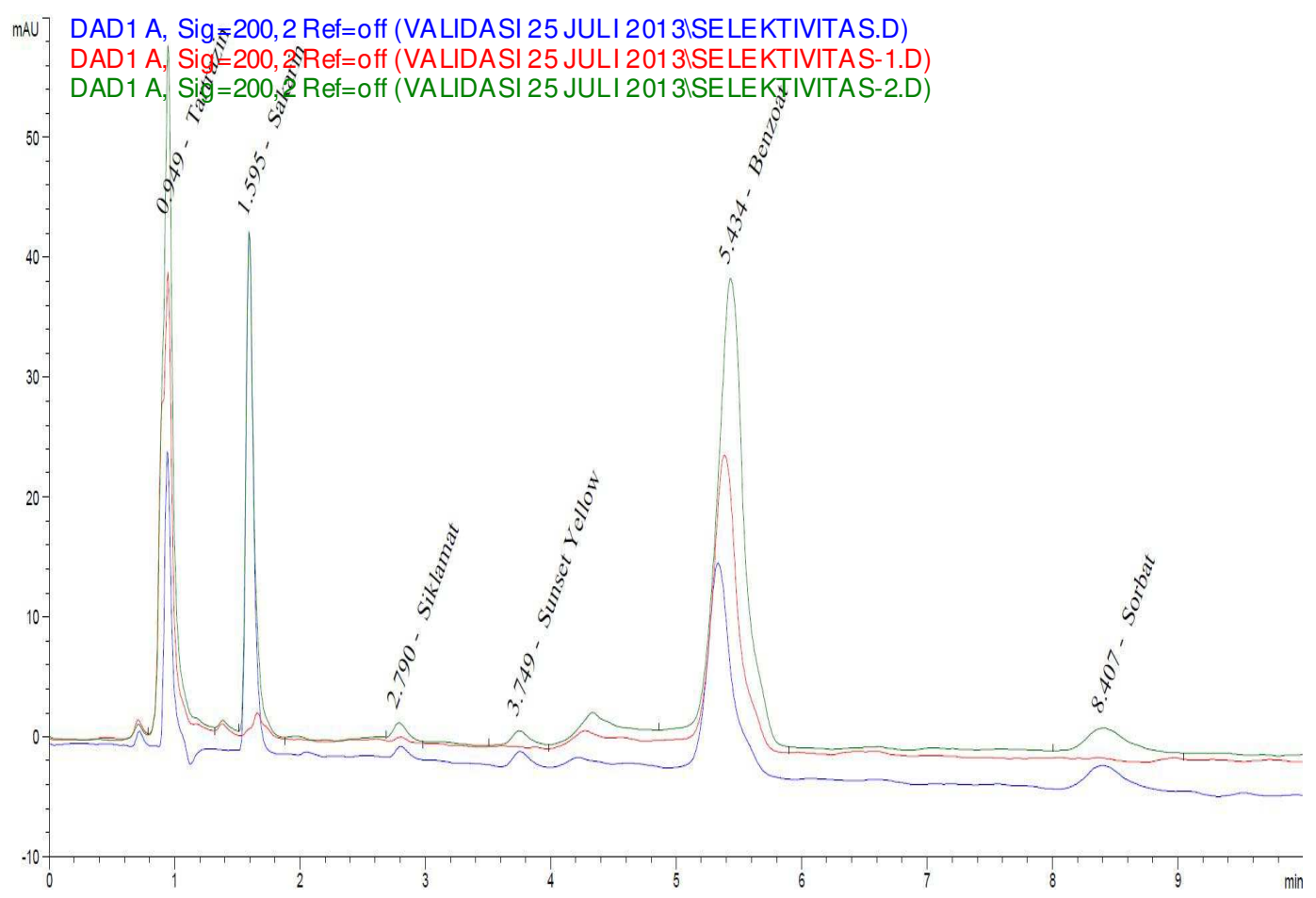

Gambar 4.16 Kromatogram Overlay Selektivitas Larutan Baku (-), Sirup X (-) dan Sirup X Ditambah Baku (-) pada Panjang Gelombang $200 \mathrm{~nm}$ Menggunakan Metode Hasil Optimasi 


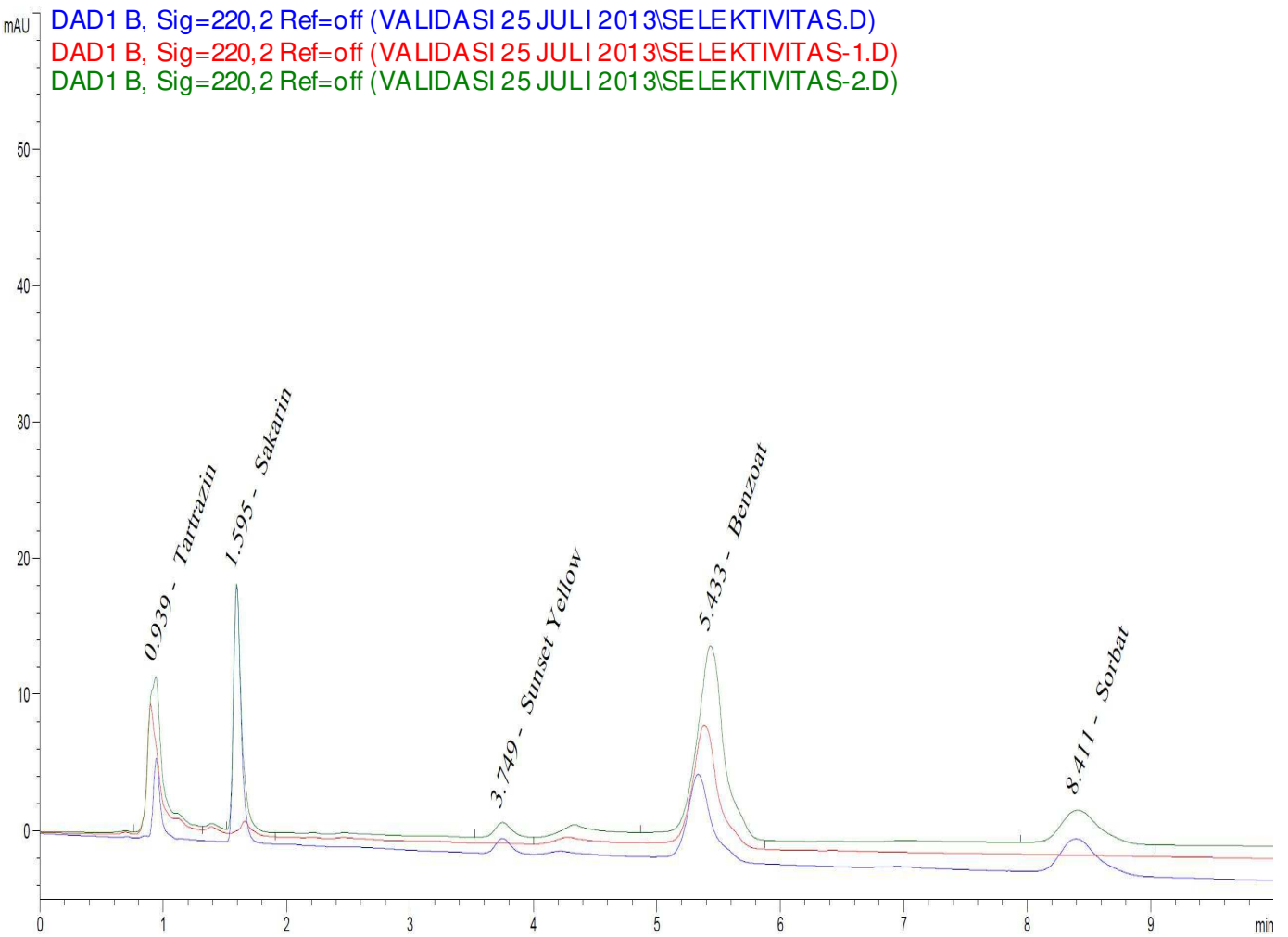

Gambar 4.17 Kromatogram Overlay Selektivitas Larutan Baku (-), Sirup X (-) dan Sirup X Ditambah Baku (-) pada Panjang Gelombang 200 nm Menggunak an Metode Hasil Optimasi

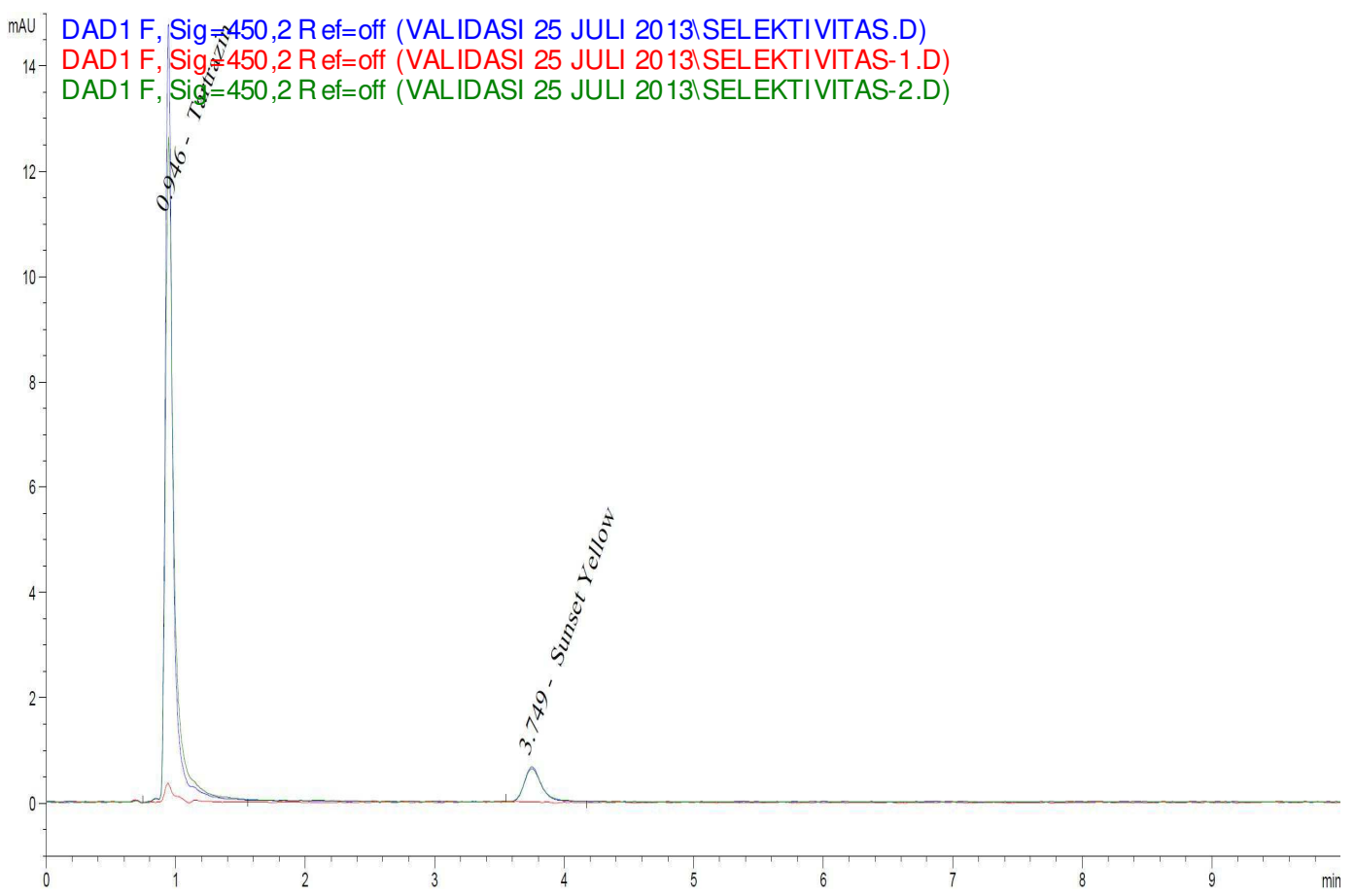

Gambar 4.18 Kromatogram Overlay Selektivitas Larutan Baku (-), Sirup X (-) dan Sirup X Ditambah Baku (-) pada Panjang Gelombang 200 nm Menggunak an Metode Hasil Optimasi 
Menurut Harmita (2004), selektivitas dapat diny atakan dengan kromatogram larutan baku, larutan sampel dan larutan sampel plus baku harus menunjukkan waktu retensi masing-masing seny awa relatif sama.

Uji selektivitas dilakukan dengan cara membandingkan kromatogram larutan baku, sirup $\mathrm{X}$ dan sirup $\mathrm{X}$ ditambah baku menunjukkan bahwa metode KCKT hasil optimasi yang diperoleh cukup selektif. Hal ini ditandai dengan waktu retensi senyawa yang diperoleh dari larutan baku, sirup $\mathrm{X}$ dan sirup $\mathrm{X}$ ditambah baku dari setiap senyawa relatif sama.

\subsection{Kadar Pemanis, Pengawet dan Pewarna dalam Sampel}

Sirup esens yang diuji berjumlah enam sampel yang diberi kode H, I, J, K, L, dan M. Penetapan kadar senyawa dilakukan sesuai dengan metode KCKT hasil optimasi. Setiap sampel dilakukan analisis pengujian sebanyak tiga kali ulangan. Kadar masing-masing senyawa dalam sampel dapat dilihat pada Tabel 4.10. Kromatogram senyawa dalam sampel dapat dilihat pada Lampiran 26, halaman 172 - 189. Luas area masing-masing senyawa dalam sampel dapat dilihat pada Lampiran 27, halaman 190 Contoh perhitungan kadar sampel dapat dilihat pada Lampiran 28, halaman 191.

Kromatogram sampel menunjukkan bahwa puncak serapan senyawa yang diuji (tartrazin, sakarin, siklamat, sunset yellow, benzoat, dan sorbat) memberikan pemisahan yang baik (Lampiran 26). Tidak terlihat adanya gangguan (overlapping) pada kromatogram masing-masing senyawa dengan zat lain. Walaupun pada setiap sampel yang diuji mengandung matriks dan komponen zat lain. Hal ini menunjukkan bahwa metode pengujian yang digunakan cukup selektif untuk mendeteksi keenam senyawa y ang dianalisis. 
Tabel 4.10 Kadar Masing-Masing Seny awa dalam Sampel

\begin{tabular}{|c|c|c|c|c|c|c|c|c|c|c|c|c|c|}
\hline \multirow{3}{*}{ No } & \multirow{3}{*}{ Kode Sampel } & \multicolumn{12}{|c|}{ Kadar Senyawa dalam Sampel } \\
\hline & & \multicolumn{2}{|c|}{ Natrium Sakarin } & \multicolumn{2}{|c|}{ Natrium Siklamat } & \multicolumn{2}{|c|}{ Natrium Benzoat } & \multicolumn{2}{|c|}{ Kalium Sorbat } & \multicolumn{2}{|c|}{ Tratrazin } & \multicolumn{2}{|c|}{ Sunset Yellow } \\
\hline & & $(\mathrm{mg} / \mathrm{kg})$ & $(\%)$ & $(\mathrm{mg} / \mathrm{kg})$ & $(\%)$ & $(\mathrm{mg} / \mathrm{kg})$ & $(\%)$ & $(\mathrm{mg} / \mathrm{kg})$ & $(\%)$ & $(\mathrm{mg} / \mathrm{kg})$ & $(\%)$ & $(\mathrm{mg} / \mathrm{kg})$ & $(\%)$ \\
\hline 1 & $\mathrm{H}$ & 494,455 & 0,049 & 4144.856 & 0,415 & 1615,360 & 0,162 & - & - & 41.957 & 0.004 & - & - \\
\hline 2 & I & 533.990 & 0.053 & 5329,890 & 0.534 & 702.569 & 0,070 & - & - & 60,468 & 0.006 & 76,478 & 0,008 \\
\hline 3 & $\mathrm{~J}$ & 302.712 & 0,030 & 4169.511 & 0.418 & 969,975 & 0,097 & - & - & 47.218 & 0 . & 41 & 0,009 \\
\hline 4 & $\mathrm{~K}$ & 217.560 & 0.022 & 3786.085 & 0,379 & 1379.582 & 0,138 & - & - & 62.459 & 0.006 & 52,588 & 0,006 \\
\hline 5 & L & 37,952 & 0.004 & 4641.830 & 0,465 & 464,456 & 0,046 & - & - & 99.894 & 0.010 & 31,084 & 0,003 \\
\hline 6 & M & 56,172 & 0,006 & 2753.140 & 0.276 & 785,238 & 0,079 & - & - & 108,048 & 0.011 & 145,399 & 0,015 \\
\hline \multicolumn{2}{|c|}{ Batas Maksimum } & 500 & 0,05 & 1000 & 0,10 & 900 & 0,09 & 1000 & 0,10 & 300 & 0,03 & 300 & 0,03 \\
\hline \multicolumn{2}{|c|}{ No. Kategori Pangan } & \multicolumn{2}{|c|}{$14.1 .4 .2^{\mathrm{a}}$} & \multicolumn{2}{|c|}{$14.1 .4 .2^{\mathrm{a}}$} & \multicolumn{2}{|c|}{$14.1 .4 .2^{b}$} & \multicolumn{2}{|c|}{$14.1 .4^{b}$} & \multicolumn{2}{|c|}{$14.1 .4 .2^{c}$} & \multicolumn{2}{|c|}{$14.1 .4 .2^{\mathrm{c}}$} \\
\hline
\end{tabular}

Keterangan :
a : BSN, 2004
b : : Badan POM RI, 2013a
c : Badan POM RI, 2013b
- $\quad$ : Tidak ditemukan dalam Sampel

14.1.4 : Minuman berbasis air berperisa, termasuk minuman olahraga atau elektrolit dan minuman berpartikel

14.1.4.2 : Minuman berbasis air berperisa tidak berkarbonat, termasuk Punches dan Ades 
Kromatogram natrium siklamat, sunset yellow dan tartrazin dalam sampel yang dianalisis memiliki puncak serapan yang rendah (Lampiran 22). Hal ini karena absorp sivitas siklamat rendah, tartrazin disebabkan kadarny a dalam sampel sangat kecil. Sedangkan sunset yellow disebabkan absorpsitivitas rendah dan kadar dalam sampel sangan kecil. Akan tetapi, kadar ketiga senyawa tersebut masih berada dalam rentang garis regresi.

Kadar natrium sakarin pada Tabel 4.10 menunjukkan bahwa sampel I melanggar aturan batas penggunaan maksimum sebesar $500 \mathrm{mg} / \mathrm{kg}$ (BSN, 2004), karena kadar natrium sakarin dari kode sampel I sebesar 533,990 mg/kg. Subani (2008), juga telah menetapkan kadar natrium sakarin dalam campuran dengan natrium benzoat dan kalium sorbat dalam sirup menggunakan KCKT dengan sampel sirup Marquisa Pohon Pisang dan diperoleh kadar sebesar $564 \mathrm{mg} / \mathrm{kg}$, di atas batas penggunaan maksimum sebesar $500 \mathrm{mg} / \mathrm{kg}$ (B SN, 2004). Kadar natrium sakarin dari sampel $\mathrm{H}, \mathrm{J}, \mathrm{K}, \mathrm{L}$ dan $\mathrm{M}$ masing-masing sebesar 494,456 mg/kg; $302,711 \mathrm{mg} / \mathrm{kg} ; 217,560 \mathrm{mg} / \mathrm{kg} ; 37,592 \mathrm{mg} / \mathrm{kg}$ dan $56,172 \mathrm{mg} / \mathrm{kg}$ masih memenuhi persyaratan karena natrium sakarin yang digunakan tidak lebih dari batas penggunaan maksimum sebesar $500 \mathrm{mg} / \mathrm{kg}$ (B SN, 2004).

Wibowotomo (2010), telah mengaplikasikan hasil dari pengembangan metode penetapan kadar siklamat berbasis Kromatografi Cair Kinerja Tinggi guna diimplementasikan dalam kajian paparan pada sediaan sirup dan diperoleh kadar siklamat sebesar $6.483,17 \mathrm{mg} / \mathrm{kg}$ untuk kota Surabay a. Hasil penelitian penetapan kadar natrium siklamat dari semua sampel berada pada rentang 2753,140 mg/kg $5329,890 \mathrm{mg} / \mathrm{kg}$ masih di bawah hasil penelitian dari peneliti Wibowotomo (2010) dan tetap berada di atas batas penggunaan maksimum sebesar $1000 \mathrm{mg} / \mathrm{kg}$ (BSN, 2004). 
Pengawet yang digunakan pada sirup esens dari semua sampel yang dianalisis adalah natrium benzoat, tanpa kalium sorbat. Kode Sampel H, J dan K diperoleh kadar natrium benzoat masing-masing sebesar 1615,360 mg/kg; $969,975 \mathrm{mg} / \mathrm{kg}$ dan $1379,582 \mathrm{mg} / \mathrm{kg}$; berada di atas batas penggunaan maksimum sebesar $900 \mathrm{mg} / \mathrm{kg}$ (Badan POM RI, 2013a). Hasil penelitian Subani (2008), menunjukkan hasil relatif sama, diperoleh natrium benzoat tanpa kalium sorbat di atas batas maksimum yang diizinkan, yaitu sebesar $1068 \mathrm{mg} / \mathrm{kg}$. Sementara Sibarani (2010), telah menetapkan kadar natrium benzoat dan kalium sorbat dalam sirup menggunakan KCKT dengan sampel dari sirup $\mathrm{ABC}$ diperoleh kadar natrium benzoat dan kalium sorbat masing-masing $373,1051 \mathrm{mg} / \mathrm{kg}$ dan 544,5627 $\mathrm{mg} / \mathrm{kg}$. Untuk sampel sirup Marjan diperoleh kadar natrium benzoat dan kalium sorbat masing-masing 377,7965 mg/kg dan 504,8255 mg/kg. Akan tetapi, hasil penelitian penetapan kadar natrium benzoat dari produsen dan produk yang sama dengan kode sampel L dan M masing-masing sebesar 464,456 mg/kg dan 785,240 $\mathrm{mg} / \mathrm{kg}$; berada di bawah batas penggunaan maksimum sebesar $900 \mathrm{mg} / \mathrm{kg}$ (Badan POM RI, 2013a), tanpa kalium sorbat. Hal ini menunjukkan ada perubahan komposisi dan kadar y ang digunakan dalam sirup.

Pewarna y ang digunak an pada sirup esens dari semua sampel y ang dianalisis adalah tartrazin dan sunset yellow, hany a pada sampel $\mathrm{H}$ yang tidak men gandung sunset yellow. Semua sampel sirup esens memenuhi persyaratan karena tidak melebihi batas penggunaan maksimum sebesar $300 \mathrm{mg} / \mathrm{kg}$ (Badan POM RI, 2013b).

Pemanis sintetis natrium sakarin tidak dicantumkan pada label kemasan dari semua sampel, sedangkan natrium siklamat hany a pada sampel H dan I. Pengawet natrium benzoat dan pewarna dicantumkan pada label kemasan untuk semua sampel sirup. Namun tetap melanggar peraturan perundang-undangan Nomor 18 
tahun 2012 tentang Pangan dan Peraturan Pemerintah Nomor 69 tahun 1999 tentang Label dan Iklan Pangan karena tidak mencantumkan jenis atau massa ataupun kedua-duany a.

Spektrum overlay natrium sakarin baku (Sigma Aldrich) dapat dilihat pada Gambar 4.19, spektrum overlay natrium siklamat dari salah satu produk yang beredar di pasar kota Medan dapat dilihat pada Gambar 4.20 dan spektrum overlay natrium siklamat baku (Sigma Aldrich) dapat dilihat pada Gambar 4.21.

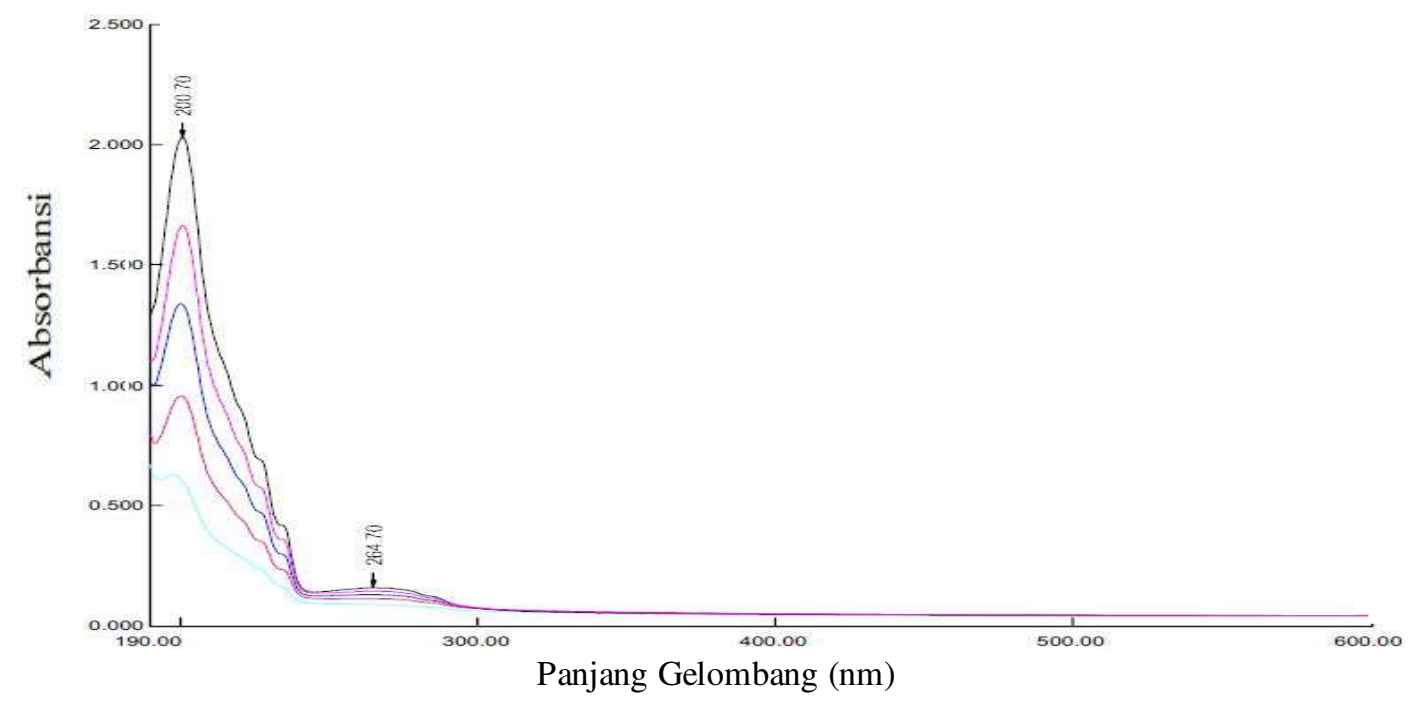

Gambar 4.19 Spektrum Overlay Natrium Sakar in Baku (Sigma Aldrich)

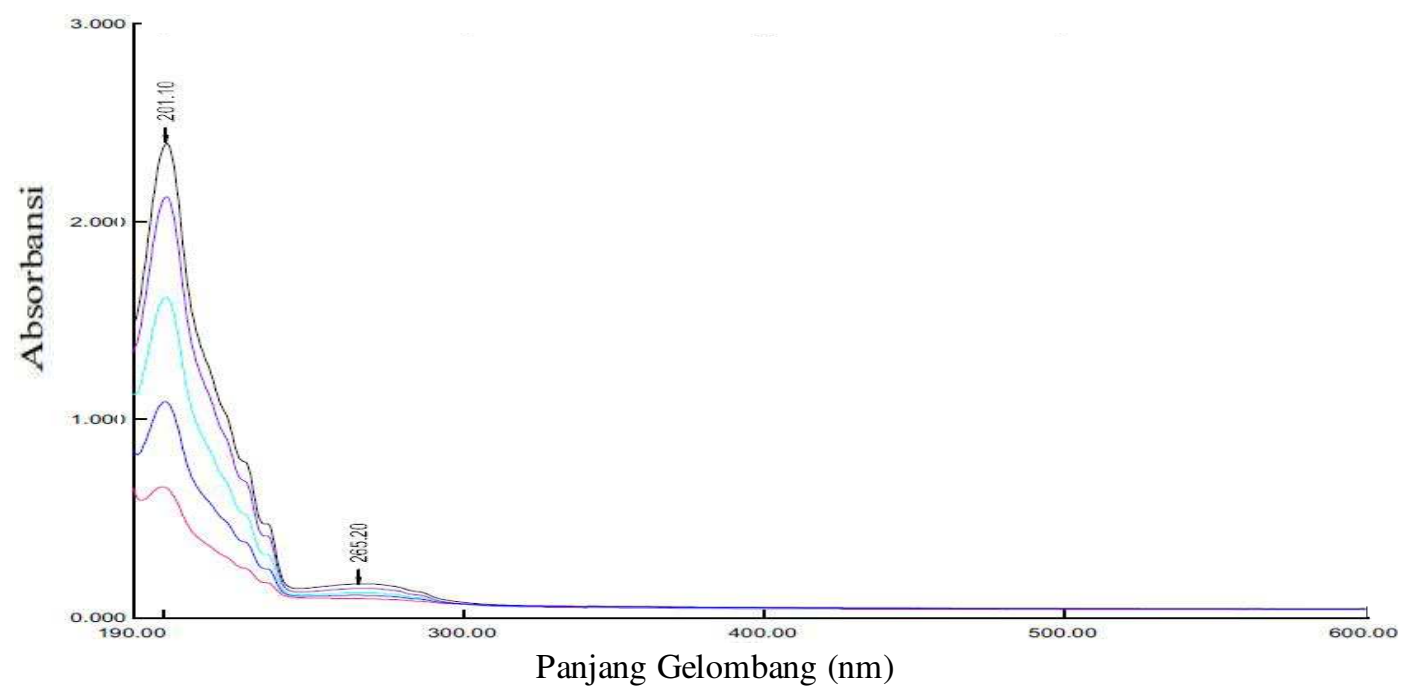

Gambar 4.20 Spektrum Overlay Natrium Siklamat dari Salah Satu Produk yang Beredar di Pasar Kota Medan. 


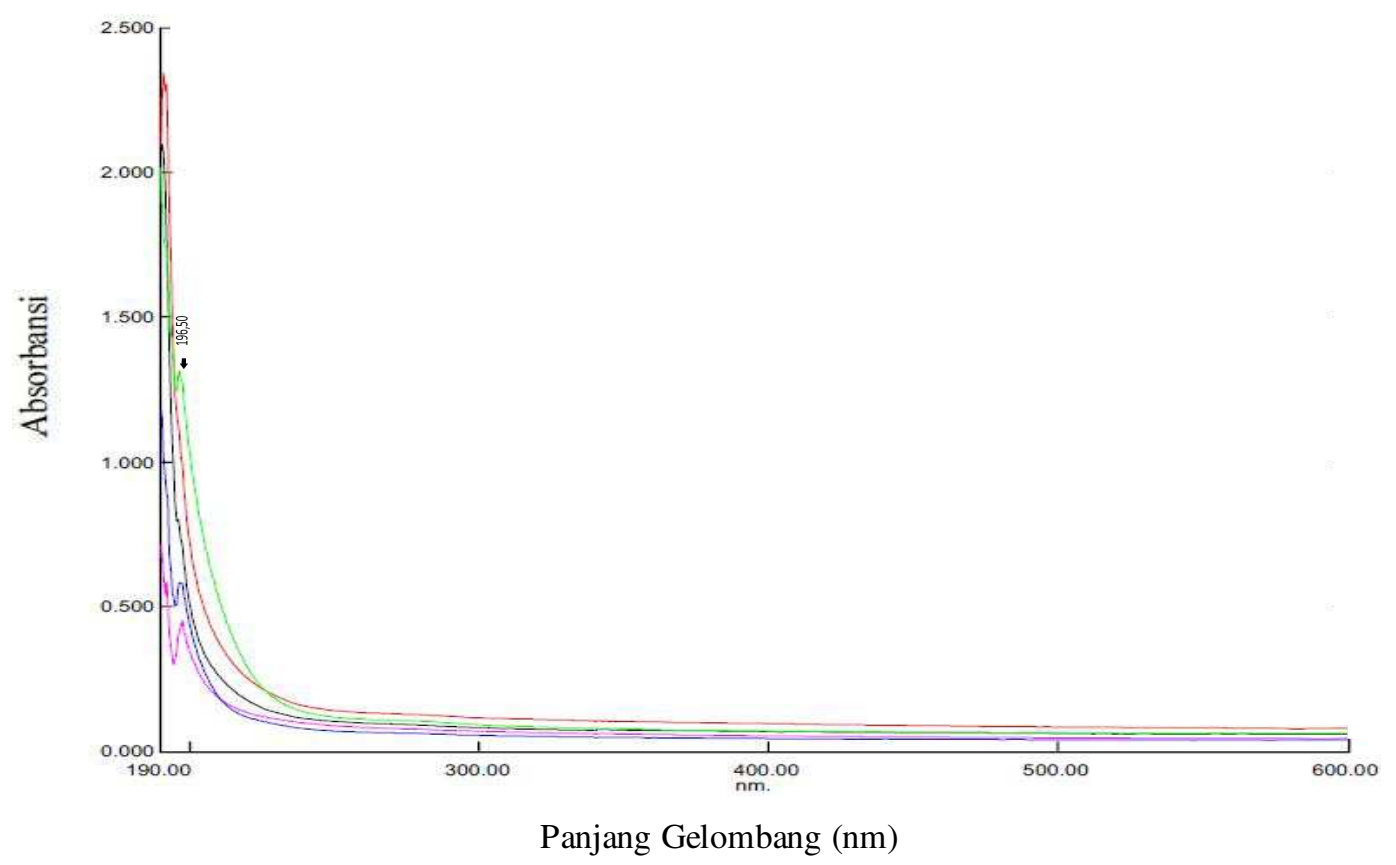

Gambar 4.21 Spektrum Overlay Natrium Siklamat Baku (Sigma Aldrich)

Gambar 4.19 sama dengan Gambar 4.20, tidak sama dengan Gambar 4.21, hal ini menunjukkan bahwa bahan baku natrium siklamat yang beredar di pasar ada y ang men gandung natrium sakarin, sehingga jika dalam produksi sirup kurang pengawasan atau tidak dilakukan quality control yang baik dapat menyebabkan natrium sakarin lebih dari batas maksimum atau ditemukan keberadaan natrium sakarin di dalam sirup esens walaupun tidak ditambahkan natrium sakarin secara sengaja.

Hasil penelitian dari beberapa peneliti sebelumnya, menunjukkan bahwa aplikasi pengembangan metode penetapan kadar pemanis, pengawet dan pewarna dalam sirup esens secara simultan dengan menggunakan KCKT relatif sama, sehingga metode yang dikembangkan layak digunakan untuk penetapan kadar pemanis, pengawet dan pewarna secara simultan pada sediaan sirup esens. 


\section{BAB V \\ KESI MPULAN DAN SARAN}

\subsection{Kesimpulan}

1. Kondisi optimum hasil optimasi pengembangan metode penetapan kadar natrium sakarin, natrium siklamat, natrium benzoat, tartrazin dan sunset yellow secara simultan menggunakan KCKT adalah volume void 30\%; panjang gelombang $200 \mathrm{~nm}$ untuk analisis natrium siklamat, $220 \mathrm{~nm}$ untuk analisis natrium sakarin, natrium benzoat dan kalium sorbat serta panjang gelombang $450 \mathrm{~nm}$ untuk analisis tartrazin dan sunset yellow; komposisi fase gerak buffer fosfat $\mathrm{pH} 4,5$ dan metanol dengan perbandingan $75: 25(\mathrm{v} / \mathrm{v})$; suhu kolom $30^{\circ} \mathrm{C}$; laju alir $1,0 \mathrm{ml} /$ menit. Hasil optimasi memenuhi persy aratan validasi dan dapat diaplikasikan pada sampel sirup esens.

2. Kadar natrium sakarin dan natrium siklamat dari enam sampel masing-masing berkisar 37,952 mg/kg - 533,990 mg/kg dan 2753,140 mg/kg - 5329,890 mg/kg. Kadar natrium sakarin di dalam sampel I sebesar 533,990 mg/kg, di atas batas penggunaan maksimum sebesar $500 \mathrm{mg} / \mathrm{kg}$ (BSN, 2004). Semua sampel mengandung natrium siklamat di atas batas penggunaan maksimum sebesar $1000 \mathrm{mg} / \mathrm{kg}(\mathrm{BSN}, 2004)$.

3. Keenam sampel sirup esens tidak men gandung kalium sorbat. Rentang kadar natrium benzoat di dalam sampel adalah 464,456 mg/kg - 1615,360 mg/kg, sampel H, J dan K masing-masing sebesar 1379,582 mg/kg; 969,975 mg/kg dan 1615,360 mg/kg; di atas batas penggunaan maksimum sebesar $900 \mathrm{mg} / \mathrm{kg}$ (Badan POM RI, 2013a). 
4. Keenam sampel sirup esens mengandung tartrazin dan sunset yellow masingmasing berkisar 41,957 mg/kg - 108,048 mg/kg dan 31,084 mg/kg - 145,399 $\mathrm{mg} / \mathrm{kg}$, di bawah batas penggunaan maksimum sebesar $300 \mathrm{mg} / \mathrm{kg}$ (Badan POM RI, 2013b).

\subsection{Saran}

Metode hasil optimasi dan validasi dapat diaplikasikan untuk penetapan kadar natrium sakarin, natrium siklamat, natrium benzoat, tartrazin dan sunset yellow pada sampel sirup esens, namun masih perlu dilakukan optimasi jenis buffer sebagai fase gerak atau fase gerak organik oleh peneliti y ang berbeda untuk matriks sampel y ang sama atau berbeda.

Produksi sirup esens perlu dilakukan pengawasan dari pihak terkait dan quality control yang lebih baik serta sosialisasi syarat mutu sirup menurut BSN perlu ditingkatkan agar kadar bahan tambahan makanan yang terdapat dalam produk tidak lebih dari batas penggunaan maksimum menurut BSN serta memenuhi syarat mutu sirup menurut BSN. 


\section{DAFTAR PUSTAKA}

Alghamdi, A.H., Alghamdi, A.F., dan Alwarthan, A.A. (2005). Determination of Content Levels of Some Food Additives in Beverages Consumed in Riy adh City. Journal King Saud Uninersity. 18(2): 99 - 109.

Allam, K.V., dan Kumari, G.P. (2011). Colorants the Cosmetics for the Pharmaceutical Dosege Form. International Journal of Pharmacy and Pharmaceutical Sciences. 3(3): 13-21.

Ambarsari, I., Qanytah dan Sarjana (2009). Penerapan Standar Penggunaan Pemanis Buatan pada Produk Pangan. Jurnal Standarisasi. 11(1): 1-12.

Angelika, Hüsgen, G., dan Schuster, R. (2001). HPLC for Food Analy sis. [diakses 12 Mei 2011]. Dikutip dari: http://www.metlab.co.uk/img/literature/ 59883294.pdf

Arikunto, S. (2002). Prosedur Penelitian. Edisi Revisi V. Jakarta: PT. Rineka Cipta. Hal. 93-101.

Badan POM RI (2006). Surat Keputusan Kepala Badan POM RI Nomor: HK.00.05.52.4040 Tentang Kategori Pangan. Jakarta: Badan POM RI. Hal. 200-203, 267-268.

Badan POM RI (2013a). Peraturan Kepala Badan POM RI No. 36 Tahun 2013 Tentang Batas Maksimum Penggunaan Bahan Tambahan Pangan Pengawet. Jakarta: Badan POM RI. Hal. 9 - 17.

Badan POM RI (2013b). Peraturan Kepala Badan POM RI No. 37 Tahun 2013 Tentang Batas Maksimum Penggunaan Bahan Tambahan Pangan Pewarna. Jakarta: Badan POM RI. Hal. 57 - 62.

BSN (Badan Standarisasi Nasional) (2004). SNI 01-6993-2004 Tentang Bahan Tambahan Pangan Pemanis Buatan - Persyaratan Penggunaan dalam Produk Pangan. Jakarta: Badan Standarisasi Nasional. Hal. 1-42.

BSN (Badan Standarisasi Nasional) (1998). SNI 01-2984-1998 Tentang Minuman Squash. Jakarta: Badan Standarisasi Nasional. Hal. 1-5.

BSN (Badan Standarisasi Nasional) (1995a). SNI 01-0222-1995 Tentang Bahan Tambahan Makanan. Jakarta: Badan Standarisasi Nasional. Hal. 1-138.

BSN (Badan Standarisasi Nasional) (1995b). SNI 01-3698-1995 Tentang Sirup Diet Diabetes. Jakarta: Badan Standarisasi Nasional. Hal. 1-3.

BSN (Badan Standarisasi Nasional) (1994). SNI 01-3544-1994 Tentang Sirup. Jakarta: Badan Standarisasi Nasional. Hal. 1-4. 
BSN (Badan Standarisasi Nasional) (1992a). SNI 01-2977-1992 Tentang Sirup Maltosa. Jakarta: Badan Standarisasi Nasional. Hal. 1-3.

BSN (Badan Standarisasi Nasional) (1992b). SNI 01-2978-1992 Tentang Sirup Glukosa. [diakses 10 Mei 2011]. Dikutip dari: http://sisni.bsn.go.id/index.php?/sni main/sni/detail sni/3370

BSN (Badan Standarisasi Nasional) (1992c). SNI 01-2985-1992 Tentang Sirup Fruktosa. Jakarta: Badan Standarisasi Nasional. Hal. 1-4.

Chan, C.C., Lam, H., Lee, Y.C., dan Zhang, X.M. (2004). Analytical Method Validation and Instrument Performance Verification. Canada: A John Wiley \& Sons Inc. Hal. 11-49.

De Lux, P.E. (2004). Kromatografi Cair Kinerja Tinggi dalam Bidang Farmasi. Medan: USU digital library. [diakses 20 Oktober 2010]. Dikutip dari: http://library.usu.ac.id/download/fmipa/farmasi-effendy 2.pdf

Diacu, E., dan Ene, C.P. (2009). Simultaneous Determination of Tartrazine and Sunset Yellow in Soft Drinks by Liquid Chromatography. Rev. Chim. 60(8): 745-749.

Dong, M.W. (2006). Modern HPLC for Practicing Scientists. Canada: A John Willey \& Sons Inc. Hal. 1-13.

EFSA (European Food Safety Authority) (2009a). Scientific Opinion on the Reevaluation of Sunset Yellow FCF (E 110) as a Food Additive. EFSA Journal. 7(11): 1330.

EFSA (European Food Safety Authority) (2009b). Scientific Opinion on the Reevaluation Tartrazine (E 102). EFSA Journal. 7(11): 1331.

Ene, C.P., dan Diacu, E. (2009). High Performance Liquid Chromatography Method for the Determination of Benzoic Acid in Beverages. U.P.B. Sci. Bull. 71(B): 81-88.

Esfandiari, Z., Badiey, M., Mahmoodian, P., Sarhangpour, R., Yazdani, E., dan Mirlohi, M. (2013). Simultaneous Determination of Sodium Benzoate, Potassium Sorbate and Natamycin Content in Iranian Yoghurt Drink (Doogh) and the Associated Risk of Their Intake Through Doogh Consumption. Iranian J. Publ. Health. 42(8): 915 - 920.

Farrar, J., dan White, D.G. (2012). Guidelines for the Validation of Chemical Methods for the FDA Food Program. [diakses 10 Januari 2012]. Dikutip dari: http://www.fda.gov/downloads/Scien ceResearch/Field Science/UCM 298730.pdf

Gautam, D., Sharma, G., dan Goyal, R.P. (2010). Evaluation of Toxic Impact of Tartrazine on Male Swiss Albino Mice. Pharmacologyonline. 1(1): 133140. 
Gritter, R.J., Bobbit, J.M., dan Schwarting, A.E. (1991). Pengantar Kromatografi. Edisi 2. Bandung: ITB. Hal. 186-239.

Gómez, M., Arancibia, V., Rojas, C., dan Nagles, E. (2012. Adsorptive Stripping Voltammetric Determination of Tartrazine and Sunset Yellow in Gelatins and Soft Drink Powder in the Presence of Cetylpy ridinium Bromide Int. J. Electrochem. Sci. 7: 7493 - 7502.

Harmita (2005). Amankah Pengawet Makanan Bagi Manusia?. Majalah Ilmu Kefarmasian. 2(2): 53-54.

Harmita (2004). Petunjuk Pelaksaan Validasi Metode dan Cara Perhitungan. Majalah Ilmu Kefarmasian. 1(3): 117-135.

Hartono, E. (2007). Pengaruh pH pada Penetapan Kadar Natrium Benzoat dalam Sirup Melalui Isolasi dengan Pelarut Eter Secara KCKT. Pharmacon. 8(1): 28-33.

Hayun, Harahap, Y., dan Aziza, C.N. (2004). Penetapan Kadar Sakarin, Asam Benzoat, Asam Sorbat, Kofeina dan Aspartam di dalam Beberapa Minuman Ringan Bersoda Secara Kromatografi Cair Kinerja Tinggi. Majalah Ilmu Kefarmasian. 1(3): 148-159.

Himri, I., Bellahcen, S., Souna, F., Belmekki, F., Aziz, M., Bnouham, M., Zoheir, J., Berkia, Z., Mekhfi, H., dan Saalaoui, E. (2011). A 90 Day Oral Toxicity Study of Tartrazine, A Synthetic Food Dye, in Wistar Rats. International Journal of Pharmacy and Pharmaceutical Sciences. 3(3): 159-169.

Huber, L. (1999). Validation of HPLC Methods. J. BioPharm. 12(1): 64-66.

Hussain, I., Zeb, A., dan Ayub, M. (2011). Evaluation of Apple and Apricot Blend Juice Preserved with Sodium Benzoate at Refrigeration Temperature. World Journal of Agricultural Sciences. 7(2): 136-142.

Hussain, I., Zeb, A., dan Ayub, M. (2010). Quality Attributes of Apple and Apricot Blend Juice Preserved with Potassium Sorbate During Storage at Low Temperature. Journal of Food Safety. 12(1): 80-86.

JECFA (Joint FAO/WHO Expert Committee on Food Additives) (1974). Toxicological Evaluation of Certain Food Additives with a Review of General Prinsiples and of Specifications. Geneva: FAO and WHO. Hal. 140.

Joseph, S. (2012). Analy sis of Color Additives in Sweets. [diakses $12 \mathrm{Maret}$ 2011]. Diambil dari: http://www.chem-agilent.com/pdf/5990-9525EN.pdf

Jurcovan, M.M., Atudosiei, N.L., dan Mihaila, D. (2012). A Simple HPLC Method for Determination of Tartrazine and Sunset Yellow in Soft Drinks Samples. Bulletin UASVM Agriculture. 69(2): 267 - 271. 
Kailasam, S. (2010). Ultrafast and Sensitive Analysis of Sweeteners, Preservatives and Flavorants in Nonalcoholic Beverages Using the A gilent 1290 Infinity LC System. [diakses 12 Maret 2011]. Diambil dari: http://www.chem.agilent.com/Library/applications/5990-5590EN.pdf

Khosrokhavar, R., Sadeghzadeh, N., Amini, M., Khansari, M.G., Hajiaghaee, R., dan Mehr, S.E. (2010). Simultaneous Determination of Preservatives (Sodium Benzoate and Potassium Sorbate) in Soft Drinks and Herbal Extracts Using High Performance Liquid Chromatography (HPLC). Journal of Medicinal Plants. 9(35): 80-87.

Kroger, M., Meister, K., dan Kava, R. (2006). Low-Calorie Sweeteners and Other Sugar Substitutes: A Review of the Safety Issues. Comprehensive Reviews in Food Science and Food Safety. 5(1): 35-47.

Lin, Y.H., Chou, S.S., Sheu, F., dan Shyu, Y.T. (2000). Simultaneous Determination of Sweeteners and Preservatives in Preserved Fruits by Micellar Electrokinetic Capillary Chromatography. Journal of Chromatographic Science. 38(1): 345 - 352.

Lopez-de-Alba, P.L., Lopez-Martinez, L., Michelini-Rodriguez, L.I., Katarzy na, W., Kazimierz, W., dan Amador, H.J. (1997). Extraction of Sunset Yellow and Tartrazine by Ion Pair Formation With Adogen-464 and Their Simultaneous Determination by Bivariate Calibration and Derivative Spectrophotometry. Analyst. 122(1): 1575-1579.

Matsunaga, A., Yamamot, A., dan Makino, M. (1985). Simultaneous Determination of Saccharine, Sorbic Acid, Benzoic Acid and Five Ester of p-Hidroxybenzoic Acid in Liquid Foods by Isocratic High Performance Liquid Chromatography. Esei Kagaku. 31(4): 269 - 273.

Nollet, L.M.L. (2000). Food Analysis by HPLC. Edisi 2. New York: Marcel Dekker, Inc. Hal. 1-53.

Novelina, Y.M., Sutanto dan Fatimah, A. (2009). Validasi Metode Analisis Penetapan Kadar Senyawa Siklamat dalam Minuman Ringan. Prosiding PPI Standarisasi; 2009; Nov 9; Jakarta: B adan Standarisasi Nasional.

Nour, V., Trandafir, I., dan Ionica, M.E. (2009). Simultaneous Determination of Sorbic and Benzoic Acids in Tomato Sauce and Ketchup Using High Performance Liquid Chromatography. Annals. Food Science and Technology. 10(1): 157-162.

Ornaf, R.M., dan Dong, M.W. (2005). Key Concepts of HPLC in Pharmaceutical Analy sis. Dalam: Handbook of Pharmaceutical Analysis by HPLC. Edisi 1. Editor: Satinder Ahuja dan Michael W. Dong. New York: Elsevier Inc. Hal. 22-45. 
Oyewole, O.I., Dere, F.A., dan Okoro, O.E. (2012). Sodium Benzoate Mediated Hepatorenal Toxicity in Wistar Rat: Modulatory Effects of Azadirachta indica (Neem) Leaf. European Journal of Medicinal Plants. 2(1): 11-18.

Pavanelli, S.P., Bispo, G.L., Nascentes, C.C., dan Augusti, R. (2011). Degradation of Food Dy es by Zero-Valent Metals Exposed to Ultrasonic Irradiation in Water Medium: Optimization and Electrospray Ionization Mass Spectrometry Monitoring. Journal of the Brazilian Chemical Society. 22(1): $111-119$.

Phomenenx (2005). HPLC Troubleshooting Guid. [diakses: 26 Februari 2013]; http://www.tecnocroma.pt/novidades/hplc-troubleshooting-guide.pdf.

Prado, M.A., Boas, L.F.V., Bronze, M.R., dan Godoy, H.T. ( 2006). Validation of Methodology for Simultaneous Determination of Synthetic Dyes in Alcoholic Beverages by Capillary Electrophoresis. Journal of Chromatography A. 1136(1): 231 - 236.

Pylypiw, H.M., dan Grether, M.T. (2000). Rapid High Performance Liquid Chromatography Method for the Analysis of Sodium Benzoate and Potassium Sorbate in Foods. Journal of Chromatography A. 888(1): 299_ 304.

Ramakrishnan, S.P., Laskmi J.B., dan Surya P.R. (2011). Estimation of Synthetic Colorant Tartrazine in Foodstuff and Formulations and Effect of Colorant on the Protein Binding of Drugs. International Journal of Pharmacy \& Industrial Research. 1(2): 141-152.

Ravichandran, V., Sahlini, S., Sundram, K.M., dan Rajak, H. (2010). Validation of Analytical Methods Strategi \& Importance. International Journal of Pharmacy and Pharmaceutical Sciences. 12(3): 18-22.

Ree, M., dan Stoa, E. (2011). Simultaneous Determination of Aspartame, Benzoic Acid, Caffeine, and Saccharin in Sugar-Free Beverages Using HPLC. Concordia College Journal of Analytical Chemistry. 2(1): 73-77.

Reuber, M.D. (1978). Carcinogenicity of Saccharin. Environmental Health Perspectives. 25(1): 173-200.

Rismana, E., dan Paryanto, I. (2007). Beberapa Bahan Pemanis Alternatif yang Aman. [diakses 10 Januari 2012]. Diambil dari: http://gulaaren.blogspot.com/2007/07/beberapa-bahan-pemanis-alternatif-y ang.html

Roberts M.W., dan Wright, J.T. (2012). Nonnutritive, Low Caloric Substitutes for Food Sugars: Clinical Implications for Addressing the Incidence of Dental Caries and Overweight. International Journal of Dentistry. 1(1): 1-8. 
Rus, V., Gherman, C., Miclauş, V., Mihalca, A., dan Nadas, G.C. (2010). Comparative Toxicity of Food Dyes on Liver and Kidney in Guinea Pigs: A Histopathological Study. Annals of the Romanian Society for Cell Biology. 15(1): 161-165.

Satuhu, S. (1994). Penanganan dan Pengolahan Buah. Jakarta: PT Penebar Swaday a. Hal. 9-52.

Serdar, M., dan Knezevic, Z. (2011). Determination of Artificial Sweeteners in Beverages and Special Nutritional Products Using High Performance Liquid Chromatography. Arh. Hig. Rada Toksikol. 62(1): 169-173.

Shimadzu (2007). Analy sis of Artificial Colorant. [diakses 12 Mei 2012]. Diambil dari: https://solutions.shimadzu.co.jp/an/s/en/lcms/24_artificial_colorant_ uflc_appn_datasheetno 24.pdf

Sibarani, M. ( 2010). Optimasi Fase Gerak Metanol-Dapar Fosfat dan Laju Alir pada Penetapan Kadar Natrium Benzoat dan Kalium Sorbat dalam Sirup dengan Metode Kromatografi Cair Kinerja Tinggi (KCKT). Skripsi. Medan: Fakultas Farmasi USU.

Snyder, L.R., Kirkland, J.J., dan Dolan, J.W. (2010). Introduction to Modern Liquid Chromatography. Edisi 3. New York: A John Willey \& Sons Inc. Hal. 20-83, 532-542, 887-890.

Snyder, L.R., Kirkland, J.J., dan Glajch, J.L. (1997). Practical HPLC Method Development. Edisi 2. New York: A John Willey \& Sons Inc. Hal. 21-97.

Snyder, L.R., dan Kirkland, J.J. (1979). Introduction to Modern Liquid Chromatography. Edisi 2. New York: A John Willey \& Sons Inc. Hal. 16165.

Subani (2008). Penentuan Kadar Natrium Benzoat, Kalium Sorbat dan Natrium Sakarin dalam Sirup dengan Metode Kromatografi Cair Kinerja Tinggi (KCKT) di Balai Besar Pengawas Obat dan Makanan Medan. Skripsi. Medan: Fakultas Farmasi USU.

Tfouni, S.A.V., dan Toledo, M.C.F. (2002). Determination of Benzoic and Sorbic Acids in Brazilian Food. Food Control. 13(1): 117 - 123.

Vachirapatama, N., Mahajaroensiri, J., dan Visessanguan, W. (2008). Identification and Determination of Seven Synthetic Dyes in Foodstuffs and Soft Drinks on Monolithic $\mathrm{C}_{18}$ Column by High Performance Liquid Chromatography. Journal of Food and Drug Analysis. 16(5): 77-82.

Varelis, P. (2008). Advances in High Performance Liquid Chromatography and Its Application to the Analy sis of Foods and Beverages. Dalam: Handbook of Food Analysis Instruments. Editor: Semih Otles. London: CRC Press. Hal. 105-115. 
Veni, N.K., Menyy anathan, S.N., Babu, B.N., Sharma, A.K., Srikanth, B.A., Saty am A.B., dan Sureh, B. (2011). Simultaneous Estimation of Colorants Sunset Yellow and Tartrazine in Food Products by RP HPLC, International Journal of Research in Pharmaceutical Sciences. 2(4): 545549.

Wibowotomo, B. (2008). Pengembangan Metode Penetapan Kadar Siklamat Berbasis Kromatografi Cair Kinerja Tinggi Guna Diimplementasikan dalam Kajian Paparan. Tesis. Bogor: IPB.

Windholz, M., Budavari, S., Stroumtsos, L.Y., dan Fertig, M.N. (1983). The Merck Index: An Encyclopedia of Chemicals, Drug and Biologicals. Edisi 9. New Jersey: Merck and Co. Inc. Hal. 352, 545, 575, 1107, 1149, 1175, 8492,8830 .

Wrolstad, R.E., Acree, T.E., Decker, E.A., Penner, M.H., Reid, D.S., Schwartz, S.J., Shoemaker, C.F., Smith, D., dan Sporns, P. (2005). Handbook of Food Analytical Chemistry. Canada: A John Willey \& Sons Inc. Hal. 647669.

Xiao, T.J., Guo, S.C., Ling, L.J., dan Yan, L.Z. (2011). Simultaneous HPLC Determination of 6 Sweeteners. Analysis Detected Food Science. 32(6): 165-168.

Zatar, N.A. (2007). Simultan Determination of Seven Synthetic Water Soluble Food Colorants by Ion Pair Reversed Phase HPLC. Journal Food and Technology. 5(3): 220-224.

Zhihong, L., dan Yanchun, Y. (1999). A Rapid Separation and Quantitation of Sodium Cyclamate in Food by Ion Pair Reversed Phase High Performance Liquid Chromatography. Chinese Journal of Chromatography. 17(3): 278 -279 .

Zygler, A., Wasik, Wasik, A.K., dan Namiesnik, J. (2011). Determination of Nine High Intensity Sweeteners in Various Foods by High Performance Liquid Chromatography with Mass Spectrometric Detection. Analytical and Bioanalytical Chemistry. 400(1): 2159-2172. 